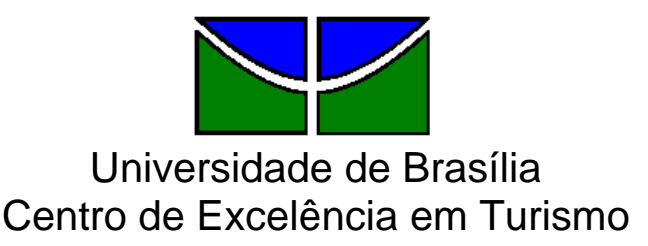

Pós-graduação Lato Sensu

Curso de Especialização em Gestão de Negócios em Turismo

\title{
PROJETO BRASÍLIA CAPITAL CULTURAL
}

VALDEMAR CUNHA SILVA

Brasília - 2009 


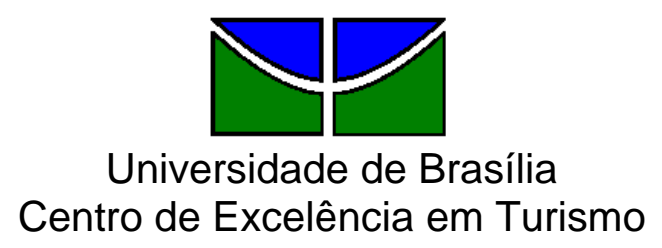

Pós-graduação Lato Sensu

Curso de Especialização em Gestão de Negócios em Turismo

\section{PROJETO BRASÍLIA CAPITAL CULTURAL}

Valdemar Cunha Silva

Professor Orientador: Domingos Spezia, MSc

Monografia apresentada ao Centro de Excelência em Turismo da Universidade de Brasília - CET/UnB, como requisito parcial à obtenção do grau de Especialista em Gestão de Negócios em Turismo.

Brasília - 2009 
Cunha Silva, Valdemar.

Projeto Brasília Capital Cultural: uma proposta / Valdemar Cunha Silva. - Brasília, 2009.

Monografia (especialização) - Universidade de Brasília. Centro de Excelência em Turismo, 2009.

Orientador: Domingos Spézia.

1 Turismo. 2. Marketing. 3. Eventos. I. Título: Projeto Brasília Capital Cultural - uma proposta. 
Universidade de Brasília

Centro de Excelência em Turismo

Pós-graduação Lato Sensu

Curso de Especialização em Gestão de Negócios de Turismo

\title{
PROJETO BRASÍLIA CAPITAL CULTURAL
}

\author{
Valdemar Cunha Silva
}

Aprovado por:

Professor Orientador: Domingos Sávio Spezia, MSc.

Professor Avaliador: Gilson Zehetmever Borba, Dr.

Professor Avaliador: José Ricardo Godinho Rodrigues, Dr.

Brasília, 10 de agosto de 2009. 
A monografia do 'Projeto Brasília Capital Cultural' é dedicada ao meu neto Lucas e minhas netas Camila, Julia, Gabriela e Sara que me motivam a prosseguir entusiasmado a descobrir novas alternativas de bem viver. Oro para que, ao longo da vida, possa viabilizar o que tanto busco orientado pelos princípios de Deus. 
Aos professores da UnB que não desanimam no ofício de ensinar com amor e dedicação sem esperar qualquer retribuição de afeto. 


\section{RESUMO}

Pretende-se averiguar a necessidade de reposicionar a imagem de Brasília desgastada pela utilização indevida por parte da imprensa local e nacional ao citar o nome da Capital (local) aos assuntos de corrupção envolvendo os Três Poderes, aqui radicados, e veiculados no País inteiro, bem como analisar as causas da baixa ocupação hoteleira de Brasília nos finais de semana e averiguar soluções possíveis. O objetivo deste trabalho e verificar se as ações do Projeto Brasília Capital Cultural são apropriadas para a solução proposta de reposicionar o nome de Brasília e alcançar maior ocupação nos finais de semana da rede hoteleira, com a realização de eventos inéditos ou especiais para as ocasiões de calendário. A metodologia básica por meio de pesquisa consubstanciou cientificamente esta hipótese ao comparar as informações e teorias da bibliografia relativa ao turismo encontrado na biblioteca da UnB. Relativo à pesquisa quantitativa, coletamos dados por meio de observações relatadas, questionários e análise documental; quanto à pesquisa qualitativa, promovemos entrevistas gravadas e/ou filmadas, com gestores e professores do segmento turístico e cultural do Governo Federal e Distrital, gerentes de hotéis, representantes de classe, do executivo e legislativo. Os principais resultados a serem alcançados nas análises de propostas relativas a eventos que façam parte do calendário turístico cultural para se tornar uma agenda a partir de 2010, sempre com eventos inéditos e periódicos, criando a integração cultural de Brasília com os outros Estados, proporcionando uma mudança de percepção da imagem de Brasília, tornando-a 'Capital Cultural' da região ou do Estado ou da cidade, e que venha estabelecer aliança em determinado período. Numa outra direção, pretende-se que Brasília esteja presente nas maiores manifestações turístico-culturais e festivais regionais do País para divulgar não somente Brasília, mas todos os Estados brasileiros, com equipamento no formato de avião que faz referência à forma arquitetônica de Brasília, cujo inventor é o herói brasileiro Santos Dumont, a quem sempre deveremos homenagear. Em outra linha, este autor enfatiza a necessidade de também criar intercâmbio turístico cultural entre todas as Capitais dos Estados brasileiros, estabelecendo com as principais cidades Administrativas do Distrito Federal 'Pontos de Turismo e Cultura' de seus Estados respectivamente. Da mesma forma, estas Administrações, em contrapartida, fariam o mesmo com a Capital do seu Estado.
1. Turismo
2. Marketing
3. Eventos 


\begin{abstract}
It is intended to determine the need to reposition the image of Brasilia eroded by misuse by the local and national press to mention the name of the Capital (local) to issues of corruption involving the Three Powers, based here, and served in the whole Country, and analyze the causes of low occupancy hotel in Brasilia on weekends and find possible solutions. The objective of this proposal is to see if the actions of the Brasilia Cultural Capital Project are suitable for the proposed solution to reposition the name of Brasilia and achieve higher occupancy on weekends with the achievement of unprecedented events or special occasions of the calendar. The basic methodology by means of scientific research substantiates this hypothesis by comparing the information and theories of literature relating to tourism found on library of UnB. On quantitative research, collect data through observations reported, questionnaires and document analysis, and the qualitative research, we recorded interviews and / or filmed, with administrators and teachers of tourism and cultural segment of the Federal and District Government, managers of hotels, class representatives, the executive and legislative. The main results to be achieved in the analysis of proposals for events that are part of the cultural tour schedule to make a calendar from 2010, with unprecedented events and journals, creating the cultural integration of Brasilia with other States, providing a change of perception of the image of Brasilia, making it the 'Cultural Capital' of the region or of state or of city, and that alliance will be in a period. In another direction, it is intended that Brasilia is present in major tourist and cultural events and regional festivals in the Country to disseminate not only the Federal District but all Brazilian States, with an equipment wich refers to a plane wich is the architectural form of Brasilia, which inventor is the Brazilian hero Santos Dumont, who we must always honor. In another line, this author emphasizes the need to also create tourist and cultural exchange between all the capitals of the Brazilian States, establishing the major Administrative cities of the Federal District 'Points of Tourism and Culture' of the states respectively. Similarly, the Administration, however, would do the same next to each State Capital.
\end{abstract}




\section{SUMÁRIO}

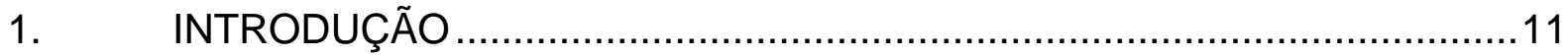

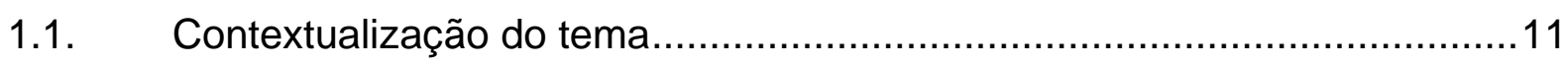

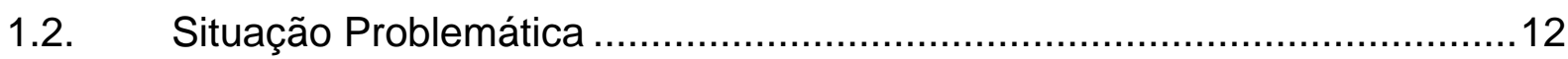

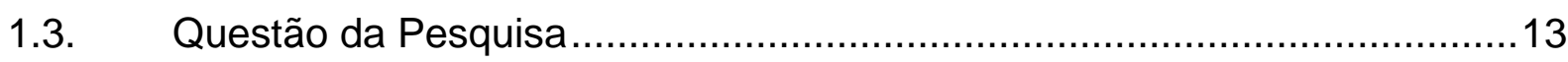

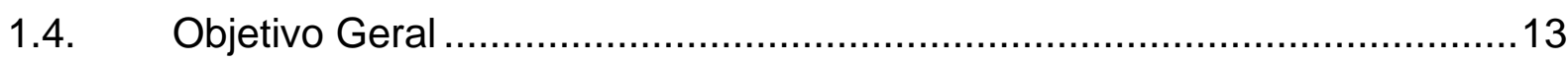

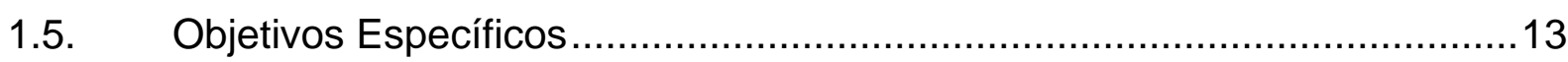

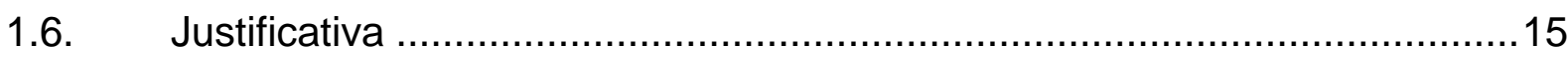

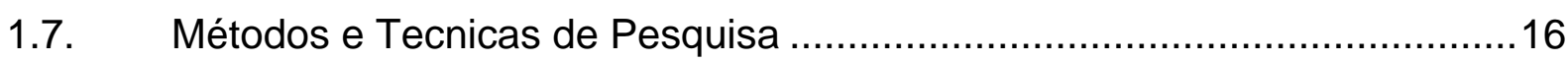

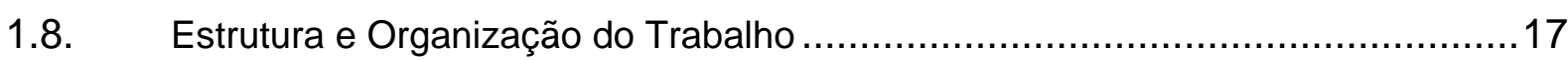

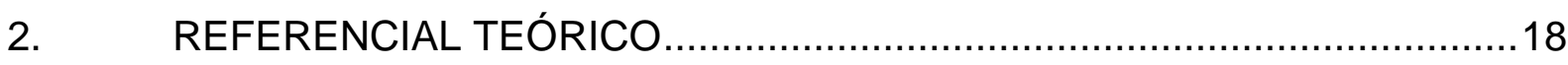

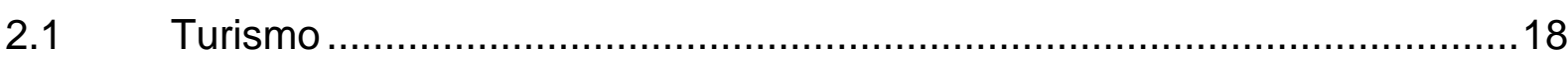

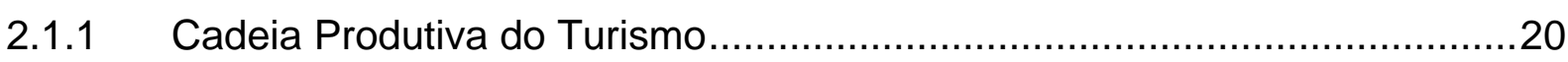

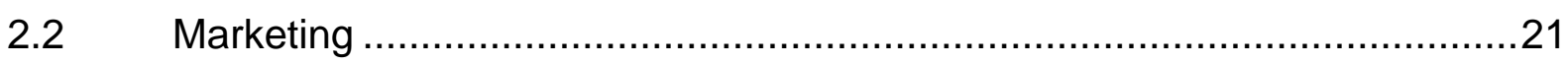

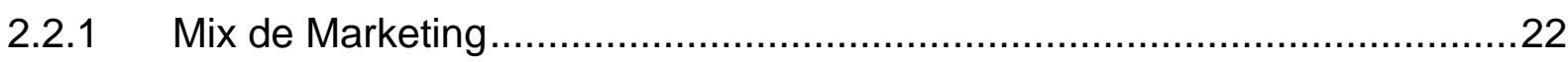

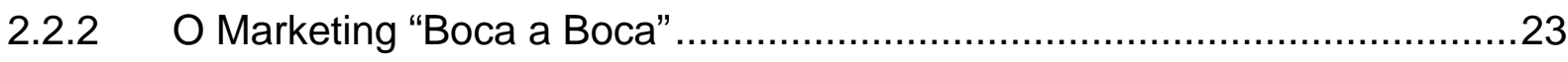

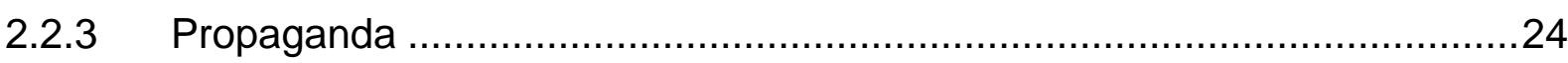

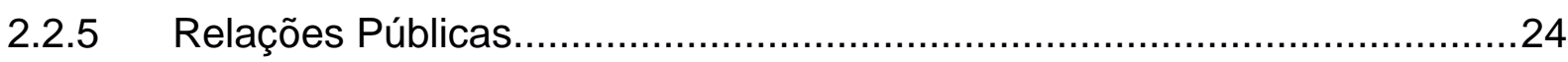

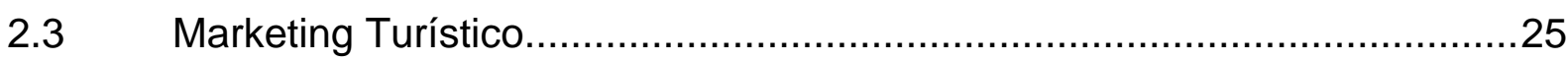

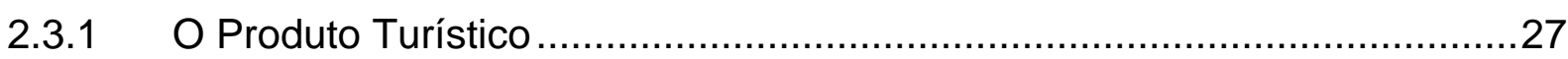

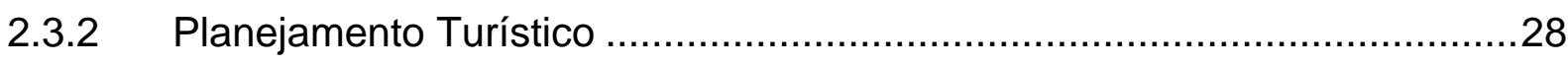

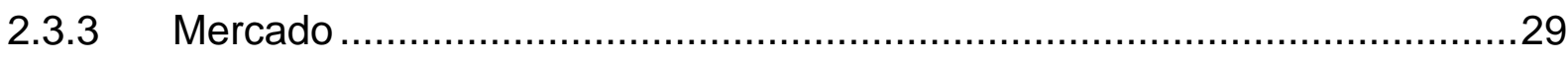

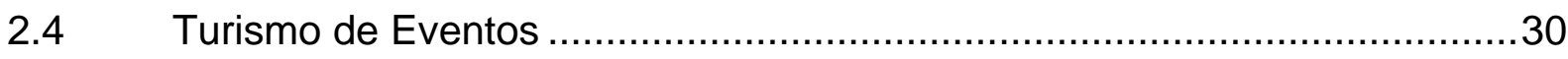

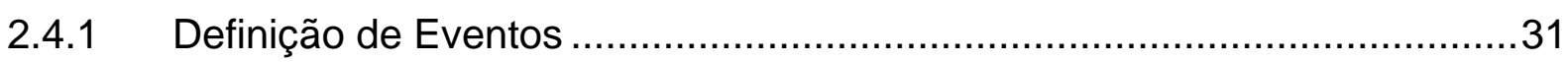

2.4.2 A Utilização de eventos como Estratégia de Marketing para Turismo ........32

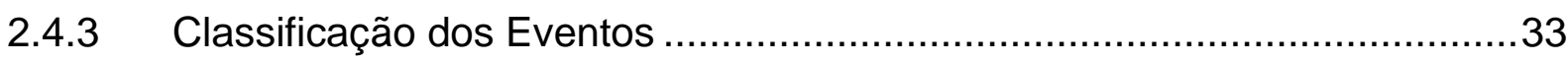

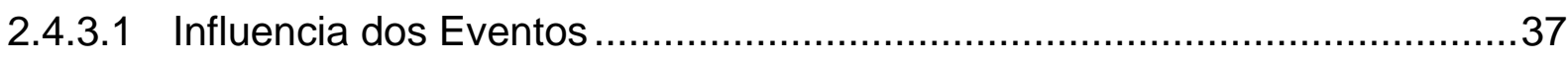

2.4.4 Eventos como Estratégia de Marketing para o Turismo.............................39

2.4.5 Impactos Físicos e Ambientais .......................................................... 40

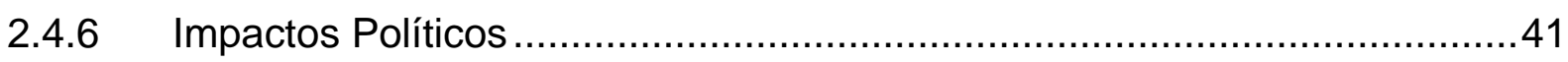

2.4.7 Turismo e Impactos Econômicos ..........................................................42

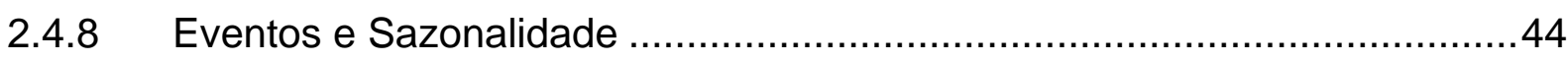

2.5 Posicionamento - Destinação Turística - Relevâncias da Imagem .............45

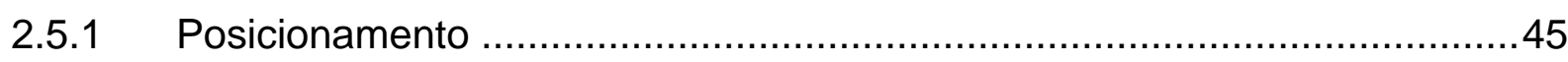

2.5.1.1 O que é uma marca e como funciona a Branding ....................................46 


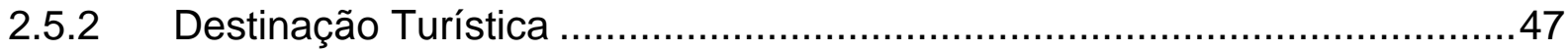

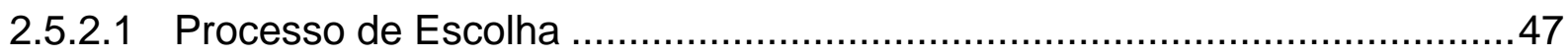

2.5.2.2 Fundamentos e Comportamento do Consumidor ...................................48

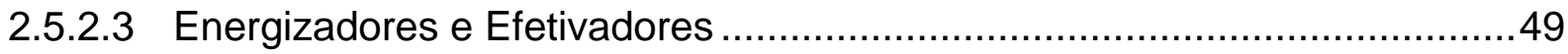

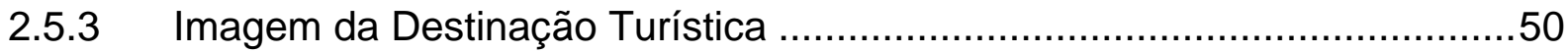

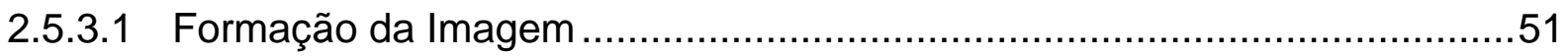

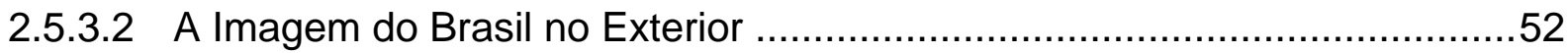

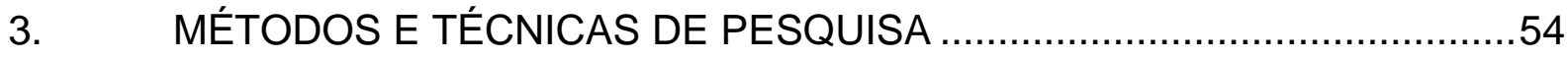

3.1. Procedimentos e instrumentos utilizados na coleta e análise dos dados....56

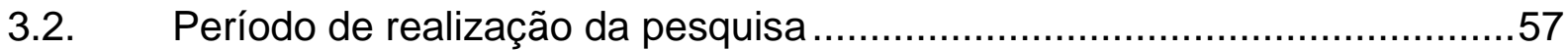

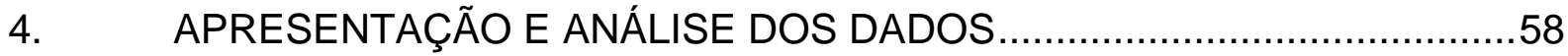

4.1. Agrupamento, ordenação e descrição dos dados coletados........................58

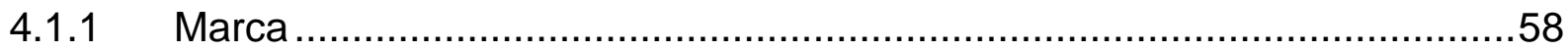

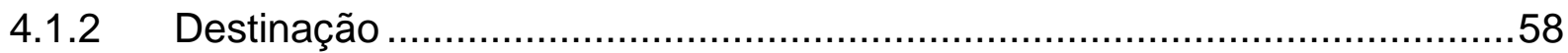

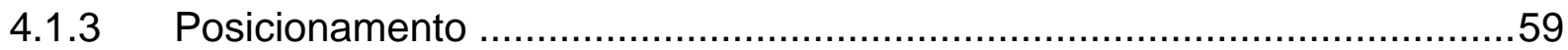

4.1.4 Proposição e Reposicionamento ......................................................59

4.1.5 Calendário Turístico Cultural de 2010 em Brasília....................................60

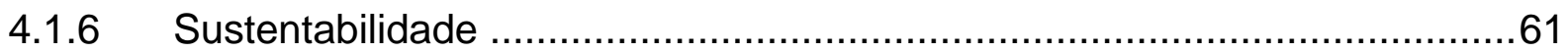

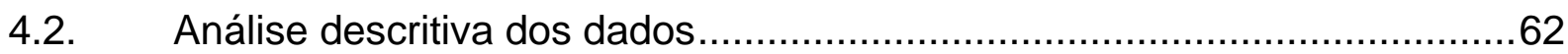

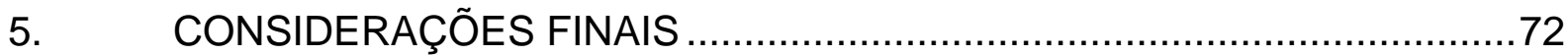

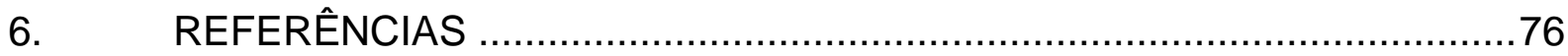

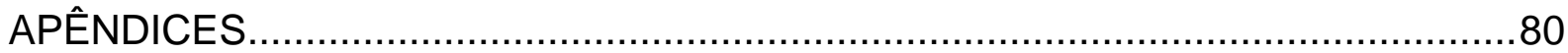

Apêndice A: Detalhamento da ação Encontros Regionais ...................................... 80

Apêndice B: Embarcações no Lago Paranoá....................................................... 88

Apêndice C: Detalhamento da Ação Espaço da Capital .......................................... 89

Apêndice D: Tabela de preço sugerida a Rede Hoteleira ........................................99

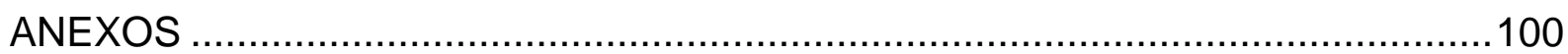

Anexo A: Empregabilidade do Turismo no País …….....................................100

Anexo B: Projeto Brasília Capital Cultural é incluido na Calendário Oficial de Eventos de Brasília pela Lei 3.328/04 .........................................................102

Anexo C: Modelo de Leiper - Agencias e Operadoras ......................................103

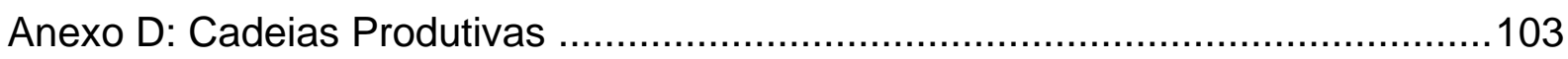

Anexo E: Decreto 84.934/80 - Atuação das Agências ..........................................104

Anexo F: Capacidade Hoteleira do Distrito Federal .........................................116 


\section{LISTA DE ILUSTRAÇÕES}

Ilustração 1 - Logomarca do Festival do Nordeste. ......................................... 80

Ilustração 2 - Logomarca do Festival do Norte.............................................. 81

Ilustração 3 - Logomarca do Festival do Sudeste................................................. 81

Ilustração 4 - Logomarca do Festival do Centro-Oeste. .........................................81

Ilustração 5 - Logomarca do Festival do Sul.................................................... 81

Ilustração 6 - Logomarcas de Brasília Capital Cultural do Nordeste; do Norte, do Sudeste; do Centro-Oeste e do Sul. ...........................................82

Ilustração 7 - Restaurantes Tradicionais e Passarela do Turismo..........................83

Ilustração 8 - Camarotes e Passarela dos Estados......................................... 84

Ilustração 9 - Expo; Passarela da Culinária; Palco Popular e Salão Eletrônico .......85

Ilustração 10 - Salão do Artesanato. ..................................................... 86

Ilustração 11 - Palco Principal e Podium do Governador. ....................................87

Ilustração 12 - Embarcações no Lago Paranoá.............................................. 88

Ilustrações 13 - Detalhamento da Ação Espaço da Capital..................................89

\section{LISTA DE TABELAS}

Tabela 1 - Empregabilidade do Turismo no País: 100 


\section{INTRODUÇÃO}

\subsection{Contextualização e o tema}

Brasília, projetada para ser a Capital da República, nasceu da decisão de um presidente visionário, Juscelino Kubitschek, e tem no traço inconfundível do arquiteto Oscar Niemeyer, vitrine do Brasil, cidade ideal para a realização de eventos. É moderna, bem equipada, com localização privilegiada, facilidade de acesso, excelente rede hoteleira e aeroporto de padrão internacional, grande diversidade de restaurantes, roteiros históricos e arquitetônicos atuais e modernos; a cidade é ditado por movimento de gente de todas as partes do País, com costumes e sotaques variados, fato que 'cai como uma luva' à proposta de um lugar que deve ligar as diversas regiões do País e promover a integração nacional; é o centro das decisões do país e influencia o Brasil inteiro por ser sede dos Três Poderes (que abriga o Congresso Nacional, principal imagem do álbum da cidade, a Esplanada dos Ministérios, a Catedral, o Memorial JK...), o que favorece a presença de autoridades nos eventos aqui realizados. É um dos nove bens brasileiros elevados a condição de 'Patrimônio Cultural da Humanidade', tratando-se da única cidade construída no século XX inscrita na lista da UNESCO. É referência nacional e segundo maior emissor de passagens aéreas do Brasil, sendo assim, a cidade tem o potencial de direcionar seu público e divulgar as festividades de cada região aqui na capital, alem de poder contar também com a atenção da mídia nacional. É a terceira maior cidade em concentração de embarcações de esporte e recreio do país, com espelho d'água de $40 \mathrm{~km}^{2}$. É um dos maiores índices de desenvolvimento urbano do mundo; tem a população atual de mais de 2.500.000 habitantes; a vida cotidiana em Brasília inclui, no lazer, programas ao ar livre no Parque da Cidade e happy hours nos bares da Asa Sul - o projeto piloto tem o formato de um avião, e é dividido por duas "asas", norte e sul, e o "corpo", a explanada dos ministérios; tem a maior renda per capta do Brasil, sendo $50 \%$ da população considerada classe média alta; tem a maior área verde entre as grandes metrópoles, sendo assim, campeã em qualidade de vida.

Um país com dimensões continentais, não poderia ser menos diversificado. Quantas culturas foram desenvolvidas e estão contidas em mais de 500 anos de história e miscigenação? E afinal, porque nós brasileiros não conhecemos tão bem nossa própria cultura, nosso meio ambiente, nosso povo? Por que, podendo promover conhe- 
cimento e reconhecimento de nossa riqueza e diversidade cultural, nos satisfazemos em permitir que se conheça o mínimo, privando o povo de tanta beleza, negando o conhecimento, aos demais sentidos, de sensações e sabores, cheiros e vivências prazerosas que um país grandioso como o nosso pode oferecer?

A resposta talvez seja tão grande quanto à incógnita e as soluções podem estar iniciando nas páginas a seguir, pois foi pensando nestas questões sociais, culturais, turísticas e de diversos outros cunhos, que surgiu a idéia desta proposição, que é levar à população o conhecimento do Brasil em Brasília, o conhecimento gerando desenvolvimento pela integração do povo no momento em a capital divulga a proximidade dos seus 50 anos, numa festa que promete ser inesquecível.

Uma vez que o turista é o centro de referência do sistema, propõe-se estudar cada fator que influenciam na sua tomada de decisão, bem como nas motivações que o impulsionam para viagens e escolha do destino. Também se pretende investigar a formação da imagem da capital e propor um reposicionamento de imagem caso seja constatado a hipótese levantada acima.

\subsection{Situação Problemática}

Os pontos positivos a respeito da capital Brasília deveriam sobressair sobre o fato de a cidade ser associada, pela imprensa, à corrupção, o que se verifica ainda não ser suficiente, quando se trata de atrair turista de lazer. Da mesma forma estes turistas potenciais têm a impressão de que os hotéis de Brasília praticam preços muito altos para o turismo de lazer.

É importante levantar uma discussão acerca da utilização das ações do 'Projeto Brasília Capital Cultural' como uma das soluções de reposicionamento da marca Brasília, incrementar novos negócios com várias ações turístico-culturais e fortalecer o nome de Brasília como 'Capital Cultural' de cada região brasileira, substituindo o estigma de cidade conhecida pela corrupção que envolve nosso país por alguns dos gestores instalados nos três poderes (executivo, legislativo e judiciário). Tem como meta, elevar a auto-estima do nosso povo e destacar os produtos turísticos culturais de cada região, em Brasília, vitrine do Brasil e foco irradiador de todas as culturas.

Pretende-se apresentar as principais características básicas organizacionais que indicam a 'sustentabilidade' do projeto que se propõe a analisar, quando se busca construir, nutrir e educar as comunidades envolvidas na realização de cada 'ação' 
nos 'Encontros Regionais' que fazem parte no ‘Projeto Brasília Capital Cultural'. Será questionado o 'antigo' conjuntamente com o 'atual' sem diminuir as chances do 'novo', por vir, com utilização dos cinco princípios (característica básicas) de organização das comunidades ecológicas; interdependência, reciclagem, parceria, flexibilidade e diversidade.

\subsection{Questão da Pesquisa}

Neste sentido apresenta-se com questão de pesquisa o seguinte: Como as realizações de eventos turísticos culturais podem contribuir para a mudança de imagem de Brasília?

\subsection{Objetivo Geral}

Demonstrar como a realizações de eventos turísticos culturais podem contribuir para a melhoria da imagem de Brasília, a partir da implementação do 'Projeto Brasília Capital Cultural'.

\subsection{Objetivos Específicos}

- Descobrir se realmente existe a necessidade de buscar um reposicionamento de imagem para Brasília, uma vez que se presume que a mesma tem seu nome arraigado a mexa da corrupção difundido no País inteiro por parte da imprensa local e nacional;

- $\quad$ Estudar se a proposta do 'Projeto Brasília Capital Cultural' é eficaz para colaborar para o reposicionamento de imagem e quais ações serão necessárias e capazes de reverter este processo difamatório;

- $\quad$ Analisar se o projeto tem potencial de também colaborar para posicionar Brasília como destino turístico atraindo turistas nos seus finais de semana;

- $\quad$ Acompanhar a realização do 'Il Encontro do Nordeste', festival turístico cultural com a participação de inúmeros artistas consagrados nacionalmente, no período de 14 a 17 de maio deste ano, e desenvolver uma ampla pesquisa com objetivo de abstrair informações para verificar o acerto ou erro das propostas do empreendimento; submeter às hipóteses levantadas e inspecionar seu resultado prático relativo à adesão dos hoteleiros, da compreensão dos gestores do Ministério do Turismo, da mídia local, entre outros importantes gestores. 
- $\quad$ Averiguar se a promoção dos 'Encontros Regionais', uma das ações do 'Projeto Brasília Capital Cultural' é capaz de valorizar o "ser brasileiro", enquanto elemento nascido de uma cultura de paz, que festeja o seu viver e promove grandes festas para exibir sua maneira tão peculiar e interessante de produzir cultura.

- Averiguar se estas promoções também têm potencial de elevar a autoestima do brasileiro, promovendo o entusiasmo por criar, agregar valor e exibir nossa cultura tão peculiar.

- $\quad$ Averiguar se a promoção do turismo interno por meio de eventos viabiliza a capital como destino.

- Verificar a viabilidade da ação, 'Calendário Turístico Cultural de 2010 em Brasília', na qual se procurará demonstrar a necessidade de Brasília receber grande ocupação hoteleira nos finais de semana com baixo preço nas diárias de hospedagem. A proposta é que a cada mês deva ser proporcionado uma ou mais atrações inéditas com o objetivo de apresentar atividades turísticos culturais de grande relevância.

- Verificar quais os períodos e respectivos eventos são mais viáveis para atração de público para serem inseridos no 'Calendário Turístico Cultural de 2010 em Brasília.

- Investigar a proposta do 'Projeto Brasília Capital Cultural', que propõe realizar mostras da cultura regional de todas as regiões, a serem exibidas na capital, mês a mês, de modo a contemplar o que se produz de melhor em todo o País, iniciando em 2009 para formar uma agenda contínua a partir de 2010, e verificar se a ações proposta a cada mês poderão ser aplicadas para a capitação de turistas.

- Verificar se os proprietários e/ou gerentes dos hotéis de Brasília estão dispostos a se unirem para a prática de promoções conjuntas; se aceitariam praticar preço especial para o 'Projeto Brasília Capital Cultural' compreendendo a necessidade de estar agregados a algumas atrações turísticos culturais relevantes;

- Verificar se as companhias aéreas também interessam reduzir o preço das passagens aéreas nos finais de semana.

- Verificar se os dirigentes do Convention \& Visitors Bureaux e da ABIH se interessam em participar das ações do projeto BCC.

- Identificar se os agentes de viagens e turismos (importantes atores neste processo, e que são os mestres dessa alquimia de combinar os mais variados ele- 
mentos para proporcionar a cada consumidor, a cada cliente, o prazer de uma jornada feliz e satisfatória) têm interesse em estudar pacotes de traslados locais com preços acessíveis.

- $\quad$ Pesquisar junto aos Deputados Federais e Senadores da bancada dos estados participantes dos 'Encontros Regionais' se apóiam financeiramente, por meio de suas emendas individuais, para promoverem as diversidades turísticas e culturais de seus Estados em Brasília, no propósito de captação de turistas, principalmente os residentes em Brasília e no Distrito Federal, a segunda maior cidade brasileira emissora de passagens aéreas;

- $\quad$ Pesquisar junto a estes mesmos Deputados Federais e Senadores se também interessam em promover uma festa (um mês antes do 'Encontro Regional' da sua região em Brasília) nas cidades que os elegeram, para convidar à população dessa cidade a vir conhecer Brasília a preços promocionais no período de realização do 'Encontro' do seu estado em Brasília; mostrar ao povo daqui à cultura dessa população e de sua região; empreender (expor e vender) produtos de artesanato, da culinária típica; apresentar a cultura local;

- $\quad$ Avaliar se a proposta de levar um equipamento (centro de eventos multiuso) em forma de avião com o objetivo de vender Brasília em conjunto com outros estados em grandes concentrações de gente, é relevante.

- $\quad$ Analisar se o intercambio turístico cultural entre as capitais brasileiras e as principais administrações regionais do Distrito Federal são relevantes.

\subsection{Justificativa}

Brasília como capital do país tem, por natureza, o dever de ser vitrine da diversidade cultural do Brasil. Detém um potencial turístico imensurável e uma vocação natural para o desenvolvimento de eventos.

A percepção de sua imagem, eventualmente conciliada à corrupção, por alguns setores da imprensa devido a escândalos políticos, limita suas possibilidades de crescimento e consolidação da marca Brasília.

É necessário mostrar que a cidade é composta de muito mais que esses fatores negativos que obscurecem sua história e sua beleza. Criar meios de explorar toda essa potencialidade em vista do desenvolvimento social, cultural e econômico. Sendo es- 
se o foco principal desse estudo, que servirá de estrutura para continuação e implementação de um projeto que já faz parte do cotidiano candango.

Proporcionar pesquisa junto aos gestores do mercado hoteleiro de Brasília afim de questionar sobre a motivação de praticarem preços diferenciados, uma vez que este seguimento tem praticado duas tabelas de preços para suas diárias, a primeira (de segunda-feira a quinta-feira) proporcionada pela grande procura dos parlamentares, empresários e gestores do poder executivo; a segunda (de sexta-feira a domingo) proporcionada por poucos visitantes, congressos ou convenções - turismo de negócios;

Pretende-se buscar sugestões junto ao trade para ampliar a ocupação nos finais de semana, bem como questionar, se as realizações das ações do 'Projeto Brasília Capital Cultural' e/ou outras promoções de eventos inéditos são alternativas boas e viáveis, e se estas ações têm potencial para buscar um reposicionamento de imagem de Brasília.

\subsection{Métodos e Técnicas de Pesquisa:}

Durante a realização do Encontro do Nordeste, no período de 14 a 17 de maio deste ano foi distribuído na entrada do festival pesquisa de levantamento junto aos participantes do evento. Na quinta feira teve atrações da Bahia, Sergipe e Alagoas, com os principais ícones, como Capital Axé, Calcinha Preta e Flor de Limão; sexta-feira com atrações da Paraíba e Ceará, como Zé Ramalho e Aviões do Forró; sábado com atrações de Pernambuco e Rio Grande do Norte, como Geraldo Azevedo / Gatinha Manhosa e Forró Brucelose; e no domingo com atrações do Piauí e Maranhão, como Francis Lopes e Tribo de Jah. Mediante análise quantitativa e qualitativa, obtevese as conclusões correspondentes aos dados coletados.

Enquanto isso, outra equipe se ocupou de pesquisar junto aos hoteleiros à proposta deste autor pela redução de preço da hospedagem combinada a promoção de eventos, por meio de entrevistas.

Da mesma forma, serão compiladas as entrevistas já realizadas no primeiro Encontro do Nordeste realizada em maio de 2008, junto aos participantes das prefeituras de Aracaju/SE, Itapipoca/CE, Campina Grande/PB, Recife/PE, o vice- governador do Maranhão a época, entre outras autoridades presentes. 


\subsection{Estrutura e Organização do Trabalho}

No Capítulo 1 - Introdução: contextualizou-se as diversas qualidades, características e vantagens de Brasília; no Capítulo 2 - Referencial Teórico: pesquisou-se e estudou-se as matérias de Turismo, Marketing, Marketing Turístico, Turismo de Eventos e Posicionamento; no Capítulo 3 - Métodos e Técnicas de Pesquisa: se propôs a realização de pesquisa quantitativa e qualitativa com os participantes do evento 'Encontro do Nordeste', dos gerentes de hotéis e companhias aéreas, dirigentes de classe, gestores de órgãos ligados ao turismo, entre outros; no Capítulo 4 - Apresentação e Análise dos Dados: verificou-se a importância de reposicionar a marca 'Brasília' e realizar um calendário turístico cultural para 2010; no Capítulo 5 - Considerações Finais: Conclui-se a necessidade existente no desenvolvimento de um trabalho de reposição de imagem da cidade, tendo como principais ferramentas a promoção dos "Encontros Regionais" e o Avião - Espaço da Capital; no Capítulo 6 Referências: pesquisou-se e estudou-se em vários livros, revistas, monografias, sites, relatórios, entre outros documentos, todos relacionados as matérias de turismo, marketing e eventos. 


\section{REFERENCIAL TEÓRICO}

\subsection{Turismo}

Para a defesa da idéia proposta nesse trabalho é de fundamental importância o conhecimento dos conceitos básicos de turismo, bem como sua compreensão, uma vez que está diretamente ligada ao objetivo de vender a "marca" Brasília como destinação turística.

"O fenômeno turístico está relacionado com as viagens, com a visita a um local diverso do de residência das pessoas. Assim, o turismo em termos históricos se iniciou quando o homem deixou de ser sedentário e passou a viajar principalmente motivado pela necessidade de comercio com os outros povos". (IGNARRA: 1998:15), apud (SALLES: 2003; 13).

Basicamente, o turismo está relacionado intrinsecamente com o ato de viajar. Essa é uma condição específica e necessária para que se possa constituir a prática turística.

Foi na Inglaterra do século XVII que surgiu o conceito de turismo referindo-se a um tipo especial de viagem. Porém, registros históricos indicam que foram os romanos os primeiros a fazer uso dessa prática, ainda no período do Império Romano.

Na Idade Média, o sistema feudal tinha como uma de suas características a fixação do homem na terra, uma vez que era essencialmente agrícola e cada feudo autosuficiente, não sendo necessários deslocamentos para fora do seu meio, já que não havia comércio. Viajar era perigoso e caro, e implicava enfrentar muito desconforto, portanto o que tornava o ato de viajar uma prática feita apenas por necessidade. Contudo, no período das Cruzadas o fluxo de peregrinos, soldados e mercadores era muito grande da Europa e, é nesse contexto, que as pousadas passam se tornar atividades lucrativas, dando origem a umas das primeiras formas de comercio turístico.

Com o advento da era industrial e o desenvolvimento da diplomacia, o turismo passou a ter um caráter educativo com o chamado "turismo neoclássico", no qual a viagem era um aprendizado, complemento indispensável da educação. É pouco após esse período que se dá a evolução dos meios de transporte como os trens e os navios, o que facilitou, de forma sem precedentes, a locomoção da população em geral, são claro, somados as melhorias nas condições de trabalho e leis trabalhistas 
que contribuíram para a inserção de outras classes as essa prática. O que deu origem ao fenômeno turístico atual, mundial e de massa.

A polissemia desse termo se dá pelo fato que de que, embora esteja relacionado com viagens, não são todas as viagens que são consideradas turismo. Contudo, mesmo as viagens consideradas não turísticas são responsáveis por grande parte da ocupação dos meios de transportes, dos hotéis, da estrutura de entretenimento, das locadoras de veículos, dos espaços de eventos.

A OMT - Organização Mundial do Turismo define turismo como "o deslocamento para fora do local de residência por período superior a 24 horas e inferior a 60 dias motivados por razões não-econômicas". Essa definição serve para padronizar o conceito de turismo nos vários países membros dessa organização, porém é incapaz de abranger a amplitude do tema.

O deslocamento de uma pessoa pode ser dar por vários fatores, as razões não econômicas citadas na definição da OMT sugere a que e a viagem turística está voltada para o lazer. Contudo, o turismo adota outras formas.

"Nos períodos de declínio ou recessão nos negócios, as empresas podem optar por uma tarifa aérea em uma classe mais barata, por hotéis mais baratos em vez dos mais caros, ou mesmo limitar a duração e o número de viagens. Abrir mão de férias anuais não será uma ameaça ao turista em potencial; não conseguir superar condições de recessão pode ser uma grande ameaça para um negócio. Então, viagens de negócio, mesmo em níveis mais inferiores, irão continuar, ao passo que as viagens a lazer podem sofrer uma grave queda devido a circunstâncias econômicas predominantes". (LICKORISH e JENKINS: 2000; 77), apud (SALLES: 2003; 14).

"A ONU classifica as viagens de negócio como turísticas não por causa da natureza das viagens, mas por considerar prioritária a demanda significativa e constante dos empresários e executivos ao mercado de bens e serviços turísticos.

As pessoas que viajam por motivos profissionais utilizam os equipamentos e serviços e, em seu tempo livre, usufruem das atrações como qualquer turista convencional". (RUFINO: 2000; 04), apud (SALLES: 2003; 15).

O turismo de negócios passa a ser outra vertente desse campo. Pois mobiliza constantemente os serviços e produtos que, inicialmente, foram criados para o turismo de lazer.

Em busca de uma definição que mais se aproxime da amplitude deste tema, ACERENZA (2002; 195), apud (SALLES: 2003; 16), diz que "o turismo é um conjunto (um grande conjunto) bem definido de relações, serviços e instalações, gerados em virtude de certos deslocamentos humanos". Essa afirmativa muda o foco da análise da atividade turística baseada no motivo da viagem para o conjunto de relações gera- 
das no ato de viajar. Essas relações, que vão da utilização de serviços e produtos feitos pelo trade com o objetivo de satisfazer as necessidades dos turistas formam a denominada cadeia produtiva do turismo.

\subsubsection{Cadeia Produtiva do Turismo}

A Cadeia Produtiva do Turismo é formada por empresas que comercializam os produtos e/ou serviços turísticos competitivos e recebe o apoio de uma rede de provedores de insumos e serviços.

"a cadeia produtiva do turismo representa o conjunto de entes econômicos que realizam as atividades e serviços que visam atender ao turista em todas as suas demandas durante as suas viagens. Embora outros agentes também possam fazer parte dos serviços que são oferecidos aos turistas, à cadeia turística compõe-se basicamente das seguintes empresas e profissionais: transportadoras, locadoras, restaurantes e afins, meios de hospedagem, guias turísticos, agências de viagens, operadoras, fornecedores de serviços, inclusive autônomos e informais, entre outros". (SOUZA: 2002; 12), apud (SALLES: 2003; 16).

"esses entes econômicos atuam de forma empresarial e competitiva, primando pela excelência dos produtos e serviços ofertados, uma vez que, a cada dia, o nível da demanda vem sendo elevada, favorecendo e mantendo no mercado, apenas aqueles que zelam pela relação de confiança com o cliente. Os obstáculos que, por ventura, apareçam, dificultando o alcance do perfil competitivo que o mercado exige, devem ser considerados como ameaças ao sucesso do negócio e trabalhos de forma a permitir a inserção da empresa nos padrões de exigência da clientela". (SOUZA: 2002; 13), apud (SALLES: 2003; 16).

A cadeia produtiva do turismo é responsável pela movimentação de toda a atividade turística. É composta por um diverso número de empresas que oferecem serviços que vão desde a venda de pacotes turísticos à locação de automóveis. Toda a rede hoteleira e de alimentação, com participação das empresas de transporte civil. Enfim, uma infinidade de entidades voltadas ao objetivo de prover o necessário para a o turista.

É necessário, porém, que haja uma completa sinergia em todos os setores envolvidos direta e indiretamente. Imprescindível, também, a consciência do empreendedor quanto às condições da atividade: infra-estrutura de apoio (acessibilidade, energia, saneamento básico, etc.), questões ambientais, fluxo de turistas, concorrência, dentre outros, que são itens essenciais para o desenvolvimento do turismo.

A cadeia produtiva do turismo deve estar em constante movimento. Buscando inovar e oferecer novos produtos, desenvolvendo novas técnicas de comercialização e estimulando a atividade em seu conjunto. A eficiência nesse trabalho é que vai influenciar diretamente na decisão do turista de viajar e, dessa forma, movimentar esse sistema. 
"O sistema turístico entra em funcionamento por meio de seu elemento dinâmico, ou seja, o turista, que coloca em movimento todo o sistema como conseqüência do deslocamento que realiza desde sua região de origem, chamada região emissora, através do caminho, até a região de destino ou receptora, e com o seu posterior regresso ao ponto inicial de partida". (ACERENZA: 2002; 200).

Os eventos passam a ser parte da cadeia produtiva do turismo. Podendo servir como um forte estimulo à opção de viajar. Uma vez que Brasília oferece serviços turísticos de excelente qualidade, servem como atrativos, pois dinamizam cotidiano da cidade e oferecem opção de entretenimento e lazer, bem como de informação, dependendo de sua natureza.

É fator significativo e de grande importância como objeto de estudo desse trabalho, que tem como foco, exatamente, a compreensão desse fenômeno em virtude de sua correta aplicação, com o intuito de fomentar e desenvolver o turismo da cidade por meio de eventos. Que além de serem parte da cadeia produtiva do turismo, são catalisadores de público e de demanda, que tende a se multiplicar em detrimento de suas ocorrências. Desse modo, é clara a necessidade de uma total sinergia entre todos os setores da cadeia produtiva e a promoção de eventos de diversas naturezas, que devem atender as expectativas de todos os setores que a compõem de uma forma geral.

\subsection{Marketing}

A idéia proposta nesse projeto sugere o fortalecimento e a afirmação do nome Brasília como uma marca que seja capaz de suscitar nas pessoas, de maneira geral, um sentimento de amor por sua capital. Imaginando encontrar na cidade um pouco de sua história, de sua cultura, uma vez que a capital é a casa do povo e que, portando, deve refletir a diversidade existente em seu país.

Nesse sentido o marketing é um instrumento fundamental para essa construção. KOTLER (2000; 33), o define como uma atividade humana dirigida que procura satisfazer as necessidades e desejos, através dos processos de troca.

Os desejos ao qual o autor se refere podem pertencer a uma ordem física, como fome, sede, necessidade de se vestir, ou, podem ser algo não tangível, como cultura, arte, lazer e outros. Todos esses elementos podem ser trabalhados de maneira a serem vinculados a valores ligados a auto-estima, status, patriotismo e etc. O que é extremamente conveniente à formulação dessa proposição, no momento em que 
visa tornar a marca Brasília algo ligado diretamente a aspectos positivos que suscitem bons sentimentos e motivem à sua visitação.

Para GRÖNROOS (1995; 47), apud CARVALHO (2003; 19), o marketing bem sucedido "requer uma forma apropriada de organizar a empresa, sendo um conjunto de ferramentas, técnicas e atividades, a que os clientes e o público da organização em geral estão expostos". Desse modo, a eficiência do marketing depende, não só do seu planejamento com fins de estabelecer uma imagem, mas dá completa sinergia desses elementos.

Quanto ao foco dessa ferramenta, dentre suas muitas definições, é consenso que sua principal preocupação deve ser o cliente.

1) "O cliente é rei", ou seja, somente com o cliente satisfeito é que se alcançam os objetivos da empresa;

2) Os clientes não compram produtos e sim o que eles trazem de vantagem para eles;

3) As ações de todos os departamentos da empresa podem ter impacto no cliente e sua satisfação, ou seja, a importância do marketing é tanta que não pode ser de responsabilidade apenas da área de marketing;

4) Os mercados e os clientes são heterogêneos e dinâmicos. Mudam constantemente, fazendo com que todo e qualquer produto tenha vida limitada, a não ser que, periodicamente, se descubra uma nova forma de satisfazer desejos e/ou necessidades dos clientes.

(HOOLEY e SAUNDERS: 1996; 37), apud (CARVALHO: 2003; 15).

Dessa forma, é necessário repensar Brasília através do conhecimento da sua percepção em relação ao país, buscando trabalhar seus aspectos de maneira a oferecer vantagens atrativas e atender as expectativas existentes.

\subsubsection{Mix de Marketing}

As empresas norteadas pelo marketing, voltadas para os clientes com o objetivo de obter vantagens competitivas, utilizam um composto de variáveis, geralmente controláveis, denominado Marketing Mix, que é representado pelos 4 P's (KOTLER: 1993; 172):

1) Produto: a empresa precisa saber o que o cliente quer, se seu produto satisfaz alguma necessidade, se oferece algum benefício e se é melhor que os similares da concorrência;

2) Preço: deve ser compatível com o que o cliente está disposto a pagar, sem deixar de ser competitivo;

3) Distribuição: o produto deve estar em lugar conveniente, onde possa ser visto e adquirido pelo consumidor;

4) Promoção: os benefícios do produto devem ser comunicados ao cliente adequado da maneira mais convincente possível. 
Este conceito é fundamental e aplicável para o objetivo de tornar Brasília uma destinação turística vendável e uma marca com poder persuasivo. Pois interage com os campos que devem ser analisados para sua reposição no cenário cultural e turístico nacional e sua consolidação positiva na mente dos "consumidores" em potencial. Porque visa estabelecer o produto em acordo com as suas necessidades e expectativas.

\subsubsection{O Marketing "Boca a Boca"}

A opinião pública é fator altamente relevante para a elaboração de uma estratégia de marketing eficaz. A percepção que o público tem de uma organização, cidade ou produto, através de suas experiências, vai definir a maneira como serão divulgado entre os seus. É um tipo de publicidade natural e que tem um forte poder de consolidação de imagem. Partindo desse pressuposto, o chamado marketing "Boca a Boca" é uma útil ferramenta para orientar os planejamentos de marketing. Segundo JERRY WILSON, apud CARVALHO: (2003; 16), o marketing "boca a boca" é um dos instrumentos de publicidade capaz de administrar o fator comentário, gerado dentro e fora de sua empresa.

"O fator comentário descreve a dinâmica do marketing "boca a boca" numa empresa. Administrá-lo, controlá-lo e direcioná-lo são as tarefas que todas as empresas devem se preocupar em realizar". (CARVALHO: 2003; 16).

Não se podem impedir as pessoas de formarem suas opiniões e tecerem seus comentários a respeito do que sentem e como vêem determinada coisa, porém, há a possibilidade de influenciar tais visões e colocações feitas. Um bom planejamento de marketing, que busque tornar a empresa, cidade ou produto, algo mais humano e mais próximo das pessoas, oferecendo um serviço de qualidade que atenda suas necessidades é primordial para essa concepção.

Contudo, no caso de Brasília, outro fator relevante é trabalhar, em conjunto com os diversos setores da sociedade, a receptividade, equivalente ao que seria o atendimento nas empresas. O exemplo disso, pode se analisar nas campanhas promovidas pelos governos da Alemanha, durante e Copa do Mundo de Futebol em 2006, e da China, nos jogos olímpicos de 2008. Quando os habitantes desses países foram estimulados a ter uma postura mais aberta e receptiva aos turistas que lá estavam em ocasião dos eventos. A proximidade entre turista e a comunidade local, gerada através de uma ação como essa, reflete diretamente na percepção da imagem da 
destinação, influenciando a opinião e concretizando o correto uso do marketing boca-à-boca.

\subsubsection{Propaganda}

A propaganda, segundo KOTLER $(1998 ; 54)$ é uma das ferramentas mais comuns que as empresas usam para dirigir comunicações persuasivas aos compradores e públicos-alvo. Ele a de fine como qualquer forma paga de apresentação impessoal e de promoção de idéias, bens ou serviços por um patrocinador identificado.

Os anunciantes não são apenas empresas comerciais, mas museus, profissionais liberais, e órgãos governamentais que divulgam suas causas a vários públicos-alvo. Anúncio são formas eficazes em termos de custo-benefício para disseminar mensagens, seja para desenvolver preferência de marca pela Coca-Cola, seja para educar os cidadãos a evitar o uso das drogas. KOTLER (1998; 554).

A aplicabilidade da propaganda nesse sentido é altamente relevante para os objetivos de destacar os aspectos positivos de Brasília e reposicionar seu nome.

A propaganda é um forte instrumento de divulgação do produto, e necessária em várias etapas da vida de uma empresa, porém, é controlada pela parte do processo que tem interesse em vender seu produto ou serviço, desta forma, geralmente, não alcança um bom índice de credibilidade junto aos consumidores. Em conjunto com marketing "boca a boca", a propaganda associa a imagem da empresa a uma idéia, cria-se uma imagem, um pensamento de qualidade e bom atendimento.

Uma vez que se pretende colocar em evidência o nome Brasília, o domínio dessa área é indispensável, desde que utilizado em sinergia com as outras técnicas voltadas para a consolidação de imagem.

..."Quando a Apple lança um produto novo de informática, a companhia procura tecer comentários a respeito de si própria antes de todos! Eles procuram certificar-se de que revendedores e associações de consumidores entendem do novo produto. Conduzem os comentários através de jornais, conferências, propaganda e mala direta"... (WILSON: 1993; 27), apud (CARVALHO: 2003; 17).

... 'A Apple tem como alvo homens de negócio, mas o 'boca a boca' reverbera para frente e para trás, espalhando-se até outros usuários potenciais, no caso, crianças, fiIhos destes clientes"... (WILSON: 1993; 27), apud (CARVALHO: 2003; 17).

\subsubsection{Relações Públicas}

As relações públicas como instrumento de formulação de imagem torna-se fundamental, uma vez que tem como princípios o equilíbrio das relações entre as instituições e seus públicos. 
Ao considerar quando e como usar RP de marketing, a administração deve estabelecer os objetivos de marketing, escolher as mensagens e veículos de relações públicas e avaliar os resultados. KOTLER (1998; 558).

O planejamento, tendo em vista nortear as ações de marketing em relação às RP, deve levar em consideração os objetivos pretendidos e dessa foram adequar a mensagem e a melhor forma de dirigi-la.

O RP de marketing é capaz de contribuir de forma eficiente, de diversas maneiras, para os objetivos alvejados. Ainda segundo KLOTER $(1998 ; 588)$ pode ajudar na:

- Construção de imagem de consciência. Veiculação de notícias na mídia para atrair a atenção para um produto, serviço, pessoa, organização ou idéia;

- Construção de credibilidade. Aumento de credibilidade ao comunicar a mensagem em um contexto editorial;

- Estímulo a vendedores e revendedores. Preparação de instrumentos para melhorar o desempenho da força de vendas e despertar o entusiasmo dos revendedores. Notícias sobre um novo produto antes de seu lançamento ajudarão os vendedores a abordar os varejistas.

- Redução de custos de promoção. Os custos de RP de marketing são menores do que os de mala direta e propaganda. Quanto menos o orçamento promocional da empresa, mais forte a razão de usar RP para ganhar a participação da mente do consumidor (share of mind).

\subsection{Marketing Turístico}

A globalização é um processo inevitável e irreversível. Os limites entre espaço e tempo são cada vez menores. O desenvolvimento dos sistemas de comunicação e transporte torna-nas cada vez menores, quando não, inexistentes. Países antes tidos como "Terceiro Mundo", passam a dar novo fôlego à economia.

Dentro desse novo contexto global o turismo se destaca como uma das atividades mais promissoras, como um mercado em rica expansão. Segundo Mário Carlos Beni: "As últimas análises apontam o turismo como o setor mais globalizado, perdendo apenas para o setor de serviços financeiros". BENI (2004; 19), apud SIMÕES e FILHO $(2002 ; 21)$. Visibilidade essa, advinda do processo de globalização e que trás em si oportunidades como crescimento do mercado em potencial, turismo começa a deixar de ser privilégio de uma elite econômica e passa pouco a pouco a atingir outras camadas sociais. E, por outro lado, desafios como o crescimento do mercado consumidor que é acompanhado por uma acirrada, às vezes desleal, competição dentro do mercado receptor.

Torna-se ainda mais difícil, dentro dá imensa variedade de atrações e destinos, alcançar uma posição de destaque. O marketing é uma forma encontrada em diversas 
localidades como forma de superar a concorrência e alcançar esse destaque. Para Carlos Meira Trigueiro, "num mercado cada vez mais globalizado e altamente competitivo, deixar de planejar e administrar estratégias de marketing torna-se suicídio para as organizações envolvidas no turismo". TRIGUEIRO (2001; 38), apud SIMÕES e FILHO (2002; 22).

Há um mercado cada vez mais competitivo na exploração do turismo como atividade econômica. Dessa forma, a função do marketing estratégico no turismo é identificar os turistas potenciais, conhecer suas necessidades e desejos passando a agrupálos distintivamente, onde são chamados de público-alvo. A partir daí identificar os segmentos onde estão esse público e posicionar o produto no mercado, utilizando de forma eficaz os recursos humanos de financeiros, são benefícios essenciais trazidos pelo marketing.

Segundo VAZ (1999), apud SIMÕES e FILHO (2002; 23), nesse caso, a motivação que leva uma pessoa a viajar merece uma abordagem precisa. O elemento que está na origem do impulso de viajar é a fonte motivadora, e podem estar ligada a diversos fatores pessoais, familiares e sociais.

Elencados esse fatores, abre-se em um leque de escolhas exponencial em relação ao motivo da viagem, que vão desde uma escolha livre de viajar, até a uma escolha repleta de fatores externos, que atravessam diversas etapas intermediárias.

Segundo VAZ (1999), apud SIMÕES e FILHO (2002; 23), esses condicionantes estão correlacionados a necessidades agrupadas em diversos tipos de interesse, como necessidade de auto preservação, de relacionamentos interpessoais, e de gratificação pessoal. São fatores que sugerem em diferentes graus de intensidade as pessoas, que respondem buscam, por meio do turismo, benefícios que atendam às privações vividas.

Contudo, torna-se complexo estabelecer correlações entre a necessidade surgida e um benefício almejado, devido à inúmera quantidade de escolhas disponíveis. $\mathrm{O}$ marketing, por sua vez, deve agir nesse momento sendo capaz de assimilar e elaborar o melhor caminho para a oferta e exploração de um grupo de consumidores.

É relevante colocar que esse estudo pretende expor a necessidade urgente de promover a capital, centro político e cultural do país, como foco irradiador de todas as culturas brasileiras, transformando a cidade em sede de cada estado. É divulgar ca- 
da região e divulgar-se em cada região, proporcionando uma integração turística cultural.

\subsubsection{O Produto Turístico}

VAZ (1999), apud SIMÕES e FILHO (2002; 24), descreve produto turístico como um conjunto de benefícios que o consumidor busca em uma determinada localidade e que são usufruídos tendo como suporte estrutural um complexo de serviços oferecidos por diversas organizações.

Defere-se que o produto turístico é composto tanto pelas ofertas naturais e culturais de um determinado lugar, quanto pelos meios que possibilitam usufruir-se de todas as formas possíveis desta oferta, que é a parte comercial.

O produto turístico, no entanto, torna-se peculiar por ser estático e não estocável. Por se tratar de um bem não tangível precisa ser consumido de maneira ininterrupta, visando manter a competitividade.

Para VAZ (1999), apud SIMÕES e FILHO (2002; 25), a sazonalidade é fator que interfere diretamente no produto turístico, uma vez que sua inflexibilidade o torna vulnerável. Um dia de chuva em uma praia, por exemplo, não pode ser recuperado ou substituído, uma data expressiva que cria vínculo com o consumidor potencial, idem. A impossibilidade de se estabelecer padrões de qualidade, ou, unidades exatas que possam servir de comparação para controle de desempenho é outra dificuldade. Isto ocorre porque é impossível conhecê-lo antecipadamente abrindo margem para diferentes expectativas, porem, "podendo ser aprimorado a cada experiência". (este autor).

Segundo VAZ (1999), apud SIMÕES e FILHO (2002; 25), o produto turístico carece de três fatores fundamentais para que seja competitivo e desejado pelos consumidores, que são: a atratividade, o pacote de serviços agregados e a prestatividade.

O marketing turístico entra como ferramenta capaz de possibilitar que a oferta do produto turístico esteja bem articulada em relação à procura, tornando o planejamento. Fator incondicionalmente necessário.

O "Marketing Turístico" encontra nesse contexto um vasto campo para crescimento. Porém, só é possível seu desenvolvimento quando governantes e sociedade traba- 
Iham juntos para promover e desenvolver o município ou região, tese desta monografia.

É importante deixar claro que "promover" a localidade através do marketing turístico não, não é apenas fazer uso da propaganda. Essa é a diferencia dessa teoria. A propaganda em si, que já obteve tanto sucesso no passado, não alcança os mesmos resultados. Para Seth GODIN “O fato de você ter dinheiro para gastar não significa ser possível comprar a atenção do público por meio da propaganda. Os consumidores já aprenderam a ignorá-la". GODIN (2004; 14), apud SIMÕES e FILHO (2002; 26). O envolvimento da população é o primeiro passo, seguido de um diagnóstico dos setores onde o município, possivelmente, pode vir a ter destaque e das suas deficiências. Somente depois de munido dessas ferramentas é possível que o trabalho possa ser realizado com boas expectativas de sucesso.

Visando a otimização do produto turístico, o trabalho de marketing turístico deve estar atento para a adoção de estratégias promovam à melhoria da cidade como um todo. O investimento deve servir para que todos os problemas estruturais sejam resolvidos e as necessidades do público (população local e turística) sejam satisfeitas. Desse modo entende-se que "(...) O produto é o marketing”. GODIN (2004; 118), apud SIMÕES e FILHO (2002; 26).

Esse é um projeto complexo, do contrário ao que se pode supor. Há muita resistência ao decorrer do projeto e, na maioria das vezes, transpassa por que teoricamente não são da incumbência de um "departamento de marketing". De toda forma, não deve fica restrito a uma limitada condição de departamento, sendo necessária a participação de todos.

\subsubsection{Planejamento Turístico}

Fazer um trabalho consistente em relação à reposição de imagem com fins desenvolver determinada localidade como destinação turística, requer um planejamento estratégico de marketing. Para o marketing, o planejamento estratégico é uma ação voltada à antecipação das oportunidades e ameaças que uma instituição terá ao buscar um posicionamento no mercado, objetivando atender as carências e desejos do seu público.

Essas estratégias podem ser definidas entre estratégias de crescimento, que visam desenvolver ações específicas para a expansão de mercado, e as de competitivida- 
de, que objetivam desenvolver ações para competir com igualdade no mercado turístico.

O planejamento turístico, visando o crescimento do produto turístico ou de uma localidade, tende a desenvolver ações programadas para atingir os objetivos mercadológicos almejados.

\subsubsection{Mercado}

No Brasil, segundo a Organização Mundial de Turismo - OMT - apud COBRA (2001; 37), apud SIMÕES e FILHO (2002; 27), estima-se que o turismo movimenta 38 bilhões de dólares de faturamento direto e indireto. Onde 7 bilhões de dólares são recolhidos em impostos diretos e indiretos. É responsável, por 5,8 milhões de empregos, tendo 38,2 milhões de turistas domésticos e 13,2 bilhões de dólares em receitas diretas.

Apesar desses dados, o Brasil ainda não pode ser considerado um país com vocação turística. A precariedade na infra-estrutura de forma geral, principalmente fora do eixo Sul-Sudeste, é um dos fatores que mais contribuem para este negativismo do turismo nacional.

Essa realidade poderia ser mudada, uma vez que, levando em consideração que, segundo dados do EMBRATUR, apud COBRA (2001; 39), apud SIMÕES e FILHO (2002; 27), existem no Brasil pelo menos 1.692 cidades com potencial turístico a ser explorado. Destas, 663 ou 39\% são considerados municípios turísticos e, outras 987 têm potenciais não aproveitados, ou explorados modestamente.

Em Brasília, seu potencial cultural e turístico pode ser medido levando em consideração pelo fato de a cidade ser um dos nove bens brasileiros elevados à condição de "Patrimônio Cultural da Humanidade", tratando-se da única cidade construída no século XX inscrita na lista da UNESCO. É moderna, bem equipada, com localização privilegiada, facilidade de acesso, excelente rede hoteleira e aeroporto de padrão internacional. É o centro das decisões políticas do país, sede dos Três Poderes, o que favorece a presença de autoridades nos eventos nela realizados. Atualmente a capital tem por volta de 2.500 .000 habitantes e detém a maior renda per capita do Brasil, onde $50 \%$ da população são consideradas de classe média alta. Tem um dos maiores índices de desenvolvimento urbano do mundo. Contando com o maior es- 
paço de área verde entre as grandes metrópoles, é uma das cidades brasileiras com melhor nível de qualidade de vida.

Todos esses dados mostram a amplitude do mercado de turismo no Brasil e, em especial, em Brasília. O enorme potencial ainda a ser explorado e que, se devidamente trabalhado, pode alavancar ainda mais o desenvolvimento local.

"O aumento do desemprego, inclusive nos locais de maior potencial turístico, gera um
reflexão importante acerca do seu desenvolvimento e das oportunidades gerados a
partir desse investimento que, em comparação ao que é necessário para desenvolver
os setores industriais e agrícolas são relativamente baixos". (COBRA: 2001; 41), apud
(SIMÕES e FILHO: 2002; 28). Os investimentos para formação de mão-de-obra para o turismo são igualmente mais baixos em comparação com outros segmentos. Levando em consideração o contingente que a indústria deixa de empregar, e os que perdem seus postos de trabalho anualmente, o turismo se apresenta como uma eficiente alternativa para geração de emprego em vários níveis de qualificação.

\subsection{Turismo de Eventos}

O setor de eventos é o responsável por uma grande parte dos fluxos turísticos de diversas destinações que, geralmente, são cidades que possuem boa infra-estrutura de serviços e equipamentos. Esses lugares podem ser vistos como catalisadores, atraindo um grande número de visitantes e estendendo sua permanência, o que tende a melhor posicionar a cidade sede no mercado, criando uma identidade turística.

"O turismo de eventos é a parte do turismo que leva em consideração o critério relacionado ao objetivo da atividade turística. É praticado com interesse profissional e cultural por meio de congressos, convenções, simpósio, feiras, encontros culturais, reuniões internacionais, entre outros, e é uma das atividades econômicas que mais crescem no mundo atual". (HOELLER: 2004), apud (ALBUQUERQUE: 2004; 12).

Grande parte das viagens de negócios inclui eventos, desse mesmo modo, as viagens para participar de eventos normalmente têm caráter profissional. Contudo, turismo de negócios e turismo de eventos são coisas distintas. Uma vez, que haja a possibilidade de que um empresário possa viajar para fechar um negócio sem que haja qualquer evento incluído na sua programação. Um turista que viaja para participar de uma festa popular, ou um estudante que viaja para um evento acadêmico, não faz uma viagem de negócio. Esses exemplos ilustram a não se necessária correlação entre essas duas práticas que geralmente estão ligadas, mas que, porém, não são iguais. 
"este é o segmento do turismo que cuida dos vários tipos de eventos que se realizam dentro de um universo amplo e diversificado. E a realização desses eventos vem proporcionar ao grupo de profissionais de uma mesma área a troca de informações, a atualização de tecnologias, o debate de novas proposições, o lançamento de um novo produto (cultural, histórico, social, industrial, comercial), que se constituem no melhor desempenho do grupo de interesse em questão. Promovendo a interação dessas pessoas, contribui-se para a geração e o fortalecimento das relações sociais, industriais, culturais e comerciais, ao mesmo tempo em que são gerados fluxos de deslocamento e visitação". (BRITTO e FONTES: 2002; 30-31), apud (ALBUQUERQUE: 2004; 12).

Observa-se, portanto, que o processo advindo da promoção de eventos irá contribuir, de forma significativa, para a utilização dos equipamentos e serviços turísticos de suas regiões promotoras, bem como para a divulgação de seus diversos atrativos. Essas estratégias comunicacionais estarão, por sua vez, implementando o crescimento da visitação e gerando a demanda específica.

\subsubsection{Definição de Eventos}

Os eventos formam parte significativa na concepção do produto turístico, pois atende intrinsecamente às exigências de mercado em matéria de entretenimento, lazer, conhecimento, descanso e tantas outras motivações. Quando adequadamente identificados com o espaço onde se realizam, podem representar a valorização dos conteúdos locais, tornando-os parte destacada da atração. Mas podem, também, apenas atender às exigências do mercado consumidor.

"o fenômeno multiplicador de negócios, pelo seu potencial de gerar novos fluxos de vi-
sitantes, ou ainda, evento é todo fenômeno capaz de alterar determinada dinâmica da
economia. Não se pode fugir da afirmativa de que existe (sic) grande complexidade e
heterogeneidade no campo do turismo e dos eventos". (COHEN: 1970), apud (ALBU-
QUERQUE: 2004; 17). Essa definição dá ênfase a importância do evento como prática econômica e sua capacidade de gerar fluxos de visitantes. De certa forma, prende-se mais em delinear seus resultados do que descrever sua formatação.

"evento é qualquer tipo de acontecimento onde as pessoas se reúnem visando troca de idéias, intercâmbios, confrarias, avaliação de projetos. Normalmente comungam com a mesma idéia e têm o mesmo objetivo". (GONÇALVES: 2003; 05), apud (ALBUQUERQUE: 2004; 17).

Para a autora o evento é um acontecimento social que agrega públicos que compartilhem de interesses em comum. Porém essa definição negligencia o aspecto objetivo do promotor do evento.

"essencialmente, o evento é uma soma de esforços e ações planejadas com o objetivo de alcançar resultados definidos junto ao seu público-alvo.

$>$ Conjunto de ações profissionais desenvolvidas com o objetivo de atingir resultados qualificados e quantificados junto ao público-alvo; 
> Conjunto de atividades profissionais desenvolvidas com o objetivo de alcançar o seu público-alvo por meio do lançamento de produtos, da apresentação de pessoas, empresas ou entidades, visando a estabelecer o seu conceito ou recuperar a sua imagem;

$>$ Realização de ato comemorativo, com ou sem finalidade mercadológica, visando a apresentar, conquistar ou recuperar seu público-alvo;

> Ação profissional que envolve pesquisa, planejamento, organização, coordenação, controle e implantação de um projeto, visando a atingir o seu público-alvo com medidas concretas e resultados projetados. (BRITTO e FONTES: 2002; 14-15), apud (ALBUQUERQUE: 2004; 18).

Todas essas propostas de ação, na realidade, envolvem a preocupação do organizador profissional de eventos em atender a todos os itens já mencionados.

Nas mãos desse profissional, o evento torna-se não apenas um produto, mas uma pequena organização dentro de um sistema organizacional maior e com vida própria, com seu próprio sistema estrutural, funcional e gerenciamento, justificando assim sua autonomia em planejamento, organização, direção e coordenação de tarefas.

Todas essas definições têm algo em comum, mas é interessante ter em foco que um evento implica mais que agradar ao público alvo, é necessário, também, gerar uma cadeia produtiva ao seu redor, aproveitamento das características originais da localidade com predisposição a sediá-lo.

\subsubsection{A Utilização de Eventos como Estratégia de Marketing para o Turismo}

O marketing turístico tem como objetivo identificar segmentos desse mercado de turismo, promover o desenvolvimento de produtos turísticos e divulgar, aos turistas em potencial, informações sobre os produtos oferecidos. O evento está inserido nesse contexto, dentro de uma seqüência de atividades, planejamento, programação e monitoramento voltado a um determinado público. Atendo-se a uma visão mercadológica, o evento pode ser analisado como um produto e, dessa forma, estabelecer critérios de planejamento para seu desenvolvimento. Elaborar a programação de um evento constitui dinamizar economicamente a sua sede através da sua relação com toda a cadeia de atividades ligadas ao turismo e potencializar as estruturas turísticas.

"Atualmente os eventos são mais essenciais à nossa cultura do que jamais foram. $O$ tempo de lazer maior e a maneira mais cuidadosa de gastar levaram à proliferação de eventos públicos, celebrações e entretenimento. Os governos de hoje apóiam e promovem eventos como parte de suas estratégias para o desenvolvimento econômico, cres- 
cimento da nação e marketing de destino. As corporações adotam eventos como elementos essenciais em suas estratégias de marketing e de promoção de imagem. $O$ entusiasmo dos grupos comunitários e indivíduos por seus próprios interesses e paixões motiva o surgimento de uma maravilhosa coleção de eventos sobre praticamente todos os assuntos e temas que se possa imaginar. Os eventos transbordam dos nossos jornais e telas de televisão, ocupam muito do nosso tempo e enriquecem nossas vidas, $\grave{A}$ medida que os eventos emergem como uma indústria em causa própria é válido considerar quais elementos caracterizam tal indústria". (ALLEM ET AL: 2002; 4).

O evento precisa ser bem planejado, concebido e gerenciado. Promover um evento movimenta uma série de recursos que estão ligados as atividades turísticas que se misturam às ações econômicas de sua sede. Desenvolve e aquece seu mercado, tornando clara a relação entre turismo e eventos.

\subsubsection{Classificação dos Eventos}

Em busca de facilitar a compreensão do vasto universo dos eventos, BRITTO e FONTES (2002; 57) apud ALBUQUERQUE (2004; 19), os classificou por:

- Categoria;

- Área de interesse;

- Localização;

- Característica estrutural;

- Tipologia.

Ainda de acordo com BRITTO e FONTES (2002; 57-61), apud ALBUQUERQUE (2004; 19), quanto à categoria, os eventos classificam-se em:

Institucional: quando visa a criar ou firmar o conceito e a imagem de uma empresa, entidade, governo ou pessoa:

Promocional ou Mercadológico: quando objetiva a promoção de um produto ou serviço de uma empresa, governo, entidade, pessoa ou local (no caso do turismo), em apoio ao marketing, visando, portanto, a fins mercadológicos.

Quanto à classificação por área de interesse, ainda segundo BRITTO e FONTES (2002; 58-59), apud ALBUQUERQUE (2004; 20), temos as seguintes áreas:

Artística: está relacionada a qualquer espécie de arte, como música, dança, pintura, poesia, literatura, teatro e outras;

Científica: trata de assuntos científicos nos campos da medicina, física, química, biologia, informática e outros em que a tônica é a pesquisa científica;

Cultural: ressalta os aspectos da cultura, objetivando sua divulgação e reconhecimento, com fins normalmente promocionais, a exemplo das feiras de artesanatos, festivais de gastronomia regional, dança folclórica, música regional, entre outros. Engloba todas as manifestações culturais regionais e folclóricas nacionais ou internacionais, abordando lendas, tradições, costumes típicos, hábitos e tendências;

Educativa: enfoca a divulgação de didáticas avançadas, cursos e novidades correlatas à educação;

Cívica: trata de assuntos ligados à Pátria e à sua história;

Política: são os eventos relacionados com assuntos das esferas políticas, sejam estes relacionados a partidos políticos, associações de classe, entidades sindicais e outros; 
Governamental: trata de realizações do governo, em qualquer esfera, nível e instância;

Empresarial: enfoca (sic) as pesquisas, resultados e realizações das organizações e seus associados;

Lazer: objetiva proporcionar entretenimento aos seus participantes;

Social: são os eventos de interesse comum da sociedade como um todo, realizações familiares ou de grupos de interesses entre amigos, visando à confraternização entre as pessoas ou comemorações específicas;

Desportiva: qualquer tipo de evento realizado dentro do universo esportivo, independente de sua modalidade;

Religiosa: trata (sic) de interesses, assuntos e confraternizações religiosas, sejam quais forem as crenças abordadas;

Beneficente: bastante comum nos dias de hoje, esses eventos refletem programas e ações sociais que são divulgados e/ou auxiliados em acontecimentos públicos;

Turística: seu objetivo é a divulgação e promoção de produtos e serviços turísticos com a finalidade de incrementar o turismo local, regional, estadual e nacional. Vem sendo utilizado com maior freqüência para incrementar o turismo de baixa estação e garantir a manutenção da oferta turística em determinada região. Costuma ser inserido em calendários oficiais de eventos do município, Estado ou país.

Quanto à localização, a classificação distingue os eventos por localização de ocorrência e, por conseguinte, estabelece seu porte e seus intervenientes. Podem ser locais (de bairro), distritais, municipais, regionais, estaduais, nacionais e internacionais. Dependendo de sua localização, deverão ser apresentados por meio de projetos de planejamento e organização relativamente complexos e relacionarem o envolvimento de serviços de terceirização e órgãos públicos referentes.

A classificação por características estruturais analisa algumas especificidades do evento, a seguir:

Pelo porte do evento, este pode ser:

Pequeno: evento com número de até 200 participantes;

Médio: evento com número de participantes estimado entre 200 e 500;

Grande: evento com mais de 500 participantes.

Pela data de realização, o evento pode ser de caráter:

Fixo: evento com data de realização invariável, de acordo com as comemorações cívicas, religiosas e outras. Realizam-se, anualmente, no mesmo dia, com periodicidade determinada;

Móvel: evento que sempre se realiza, porém em data variável, segundo o calendário ou os interesses da organização promotora;

Esporádico: evento de realização temporária, que acontece em função de fatos extraordinários, porém previstos e programados.

Pelo perfil dos participantes, o evento pode ser de caráter: 
Geral: evento organizado para uma clientela em aberto, limitada apenas a função da capacidade do local de realização. Algumas vezes pode haver algum fator de restrição, como por exemplo, a idade. Ex.: desfile de escola de samba;

Dirigido: evento restrito a um público que possui afinidades com o tema. De modo geral, esse público se subdivide em grupos de interesses diversificados. Um salão do automóvel, por exemplo, agrupa (sic) produtores, comerciantes, usuários, colecionadores, etc;

Específico: evento realizado para o público claramente definido pela identidade de interesse pelo assunto. Ex.: congressos da área médica.

Podem ser classificados quanto a sua tipologia, isto é, seu tipo, sua característica mais marcante. Os mais utilizados e que representam maior movimentação para a infra-estrutura turística são: BRITO e FONTES (2002), apud ALBUQUERQUE (2004; 23),

\begin{tabular}{|c|l|}
\hline Programas de Visitas & Famtour \\
& Openday \\
\hline Exposições & Feiras \\
& Exposições \\
& Road-Shows \\
& Show case \\
& Mostras \\
& Salões \\
& Vernissages \\
\hline Encontros Técnicos e Cien- & Congressos \\
tíficos & Conferências \\
& Videoconferências \\
& Convenções \\
& Siclos de Palestras \\
& Simpósios \\
Pesas-Redondas & Seminários \\
& Debates \\
Conclaves \\
Brainstormings \\
Semanas \\
Jornadas \\
Concentrações \\
Entrevistas Coletivas \\
Workshops \\
Oficinas \\
Assembléias \\
Estudos de caso \\
Comícios \\
Passeatas \\
Carreatas \\
\hline Saraus \\
\hline
\end{tabular}




\begin{tabular}{|c|c|}
\hline Encontros de Conveniência & $\begin{array}{l}\text { Coquetéis } \\
\text { Happy-hours } \\
\text { Chás da tarde } \\
\text { Chás-de-bebê } \\
\text { Chás-de-cozinha } \\
\text { Chás beneficentes } \\
\text { Chás-bar } \\
\text { Almoços } \\
\text { Jantares } \\
\text { Banquetes } \\
\text { Cafés da manhã } \\
\text { Brunches } \\
\text { Coffee-breaks } \\
\text { Guest Coffees } \\
\text { Encontros Culturais } \\
\text { Shows } \\
\text { Festivais }\end{array}$ \\
\hline Cerimônias & $\begin{array}{l}\text { Cerimônias de cunho religioso } \\
\text { Cerimônias fúnebres } \\
\text { Casamentos } \\
\text { Bodas } \\
\text { Cerimônias de posse } \\
\text { Cerimônias acadêmicas } \\
\end{array}$ \\
\hline Eventos competitivos & $\begin{array}{l}\text { Concursos } \\
\text { Gincanas } \\
\text { Torneios } \\
\text { Campeonatos } \\
\text { Olimpíadas }\end{array}$ \\
\hline Inaugurações & $\begin{array}{l}\text { Espaços físicos } \\
\text { Monumentos }\end{array}$ \\
\hline Lançamentos & $\begin{array}{l}\text { De pedra fundamental } \\
\text { De livros } \\
\text { De empreendimentos imobiliários } \\
\text { De maquetes } \\
\text { De produtos } \\
\text { De servicos }\end{array}$ \\
\hline Excursões & $\begin{array}{l}\text { Técnicas } \\
\text { De incentivo } \\
\text { Educacionais }\end{array}$ \\
\hline Desfiles & $\begin{array}{l}\text { Desfiles cívicos } \\
\text { Desfiles de moda }\end{array}$ \\
\hline Leilões & Variados \\
\hline Dias específicos & Variados \\
\hline Outros & Variados \\
\hline
\end{tabular}




\subsubsection{Influência dos Eventos}

Para de delinear a importância e a influência dos eventos, é necessário sua compreensão como fenômeno que interage várias áreas.

"devem ser considerados como geradores significativos de riquezas, tanto tangíveis, quanto intangíveis, para a cadeia produtiva do local, por parte das lideranças políticas e, principalmente, das lideranças empresariais. O desenvolvimento de uma nação pode começar pelo município, o qual, comparativamente a um ser biológico, é como órgão vital do corpo de um país. O fortalecimento e a saúde econômica do município significam garantia de força competitiva e de riqueza para o país como um todo". (TOMAZZONI: 2003; 03), apud (ALBUQUERQUE: 2004; 22).

No que condiz a sua relevância quanto ao turismo.

"o turismo baseado em eventos tornou-se um componente fundamental dos programas de atração turística. Os lugares pequenos ou rurais geralmente começam com um festival ou outro tipo de evento para definir sua identidade”. (KOTLER e REIN: 1995; 223), apud (ALBUQUERQUE: 2004; 23).

Apesar de ser constatada sua necessidade, a promoção do turismo encontram alguns entraves que dificultam a sua viabilidade. O que representa uma perda considerável na movimentação que produz.

"Percebe-se que uma das principais dificuldades para um maior desenvolvimento da área de eventos é a ausência de uma gestão adequada das parcerias e da cooperação entre as organizações do setor privado e do poder público". (ALBUQUERQUE: 2004; 24).

"o desenvolvimento do binômio eventos-turismo, em uma economia de livre mercado, só é possível em um ambiente favorável ao empreendedorismo, o qual deve conjugar os fatores culturais, tecnológicos, políticos e econômicos. (TOMAZZONI: 2003; 04), apud (ALBUQUERQUE: 2004; 25).

Um ambiente favorável ao empreendedorismo constitui um contexto onde o incentivo a prática, tanto quanto a eliminação de barreiras burocráticas, sejam estimuladas visando dinamizar o processo de promoção dos eventos que agregam à sociedade. Não só isso, mas também, desenvolver a estrutura física pra que isso ocorra.

"as atividades sociais, turísticas e de lazer poderão fazer parte de uma programação
elaborada com o intuito de entreter convidados e participantes, ao mesmo tempo em
que promova a cidade e seus atrativos turísticos. Considera-se, desta forma, que as ci-
dades-sedes de evento devam oferecer atrativos e estrutura turística capazes de res-
ponder positivamente aos desejos dos visitantes". (BRITTO e FONTES: 2002; 176-
177), apud (ALBUQUERQUE: 2004; 27). Geralmente, cidades que possuem um amplo potencial, com boa infra-estrutura de serviços e equipamentos e, no entanto, não têm nenhuma tradição na prática do turismo são destinações do setor de eventos que é o responsável por uma grande parte dos fluxos turísticos. Esses lugares podem ser vistos como catalisadores capazes de atrair um grande número de visitantes e estendendo sua permanência, dando a localidade uma identidade turística e a melhor posicionando no mercado. Assim, pu- 
blicidade gerada pelo evento, promovendo e divulgando a cidade sede é o que vislumbram grandes centros. Nesses casos, os eventos atuam como referencial para mídia, que expõe o destino em nível regional, nacional ou até mesmo internacional.

O planejamento dos eventos garante a chegada de turistas de várias regiões do país que, em sua maioria, irão consumir todos os tipos de serviços oferecidos. Isso mostra as relações existentes entre o setor de eventos e o marketing e a sua importância sócio-econômica para um determinado local, uma vez que, estima-se serem criados quatro empregos diretos e indiretos por cada congressista que se recebe em uma localidade.

Segundo Mario Carlos BENI, no Brasil, o setor de eventos, somente em 2001, havia gerado uma renda de aproximadamente US\$37 milhões, e criado 777.624 mil empregos diretos ou terceirizados, e aproximadamente outros três indiretos para cada um destes. BENI (2004; 52), apud ALBUQUERQUE (2004; 28).

Existem inúmeros benefícios gerados por esse segmento, segundo informações obtidas no I Dimensionamento Econômico da Indústria de Eventos no Brasil, publicado pelo SEBRAE em parceria com o Fórum Brasileiro Convention \& Visitors Bureau, nos anos de 2001-2002, acontecem anualmente no país mais de 330 mil eventos, envolvendo 79,9 milhões de participantes. Somando-se os gastos dos participantes, a receita das locações e das empresas organizadoras, chega-se a uma renda total de R\$ 37 bilhões por ano. Em termos de geração de empregos, a indústria de eventos responde anualmente por cerca de três milhões de empregos diretos, terceirizados e indiretos. A arrecadação de tributos gerada é estimada em $R \$ 4,2$ bilhões.

Seguindo ainda a proposta de alavancar o setor de turismo por meio de eventos periódicos.

Em relação aos benefícios sociais gerados, o setor de eventos, ainda segundo o estudo publicado pelo SEBRAE, tem um desempenho significativo no estímulo para o desenvolvimento das micro e pequenas empresas que hoje representam, no panorama econômico nacional, cerca de 90\% do total de empresas brasileiras, com 94\% de atuação no setor de serviços exercendo relevante papel na área de terceirização. O setor de eventos é uma importante fonte geradora de empregos em todo o país. Cada espaço de eventos contrata, em média, 6,8 funcionários fixos. Este número multiplicado pelos 1.780 espaços, resulta em 12.104 postos de trabalho diretos, aos 
quais se deve acrescentar 58.240 empregos terceirizados. As empresas organizadoras contratam em média 24,2 empregados fixos e 386,6 terceirizados. Considerando apenas o universo de 400 empresas e entidades que constam desta pesquisa, o número de empregos chega a 164.320 diretos e 492.960 terceirizados, num total de 657.280 .

No que diz respeito a Brasília, a AMBr Revista (2003; 10-11), apud ALBUQUERQUE $(2004 ; 26)$, baseada nos desse mesmo estudo, indica que a cidade detém rede hoteleira de alta qualidade, com as melhores bandeiras do mundo, e oferece mais de 17 mil leitos. A oferta total de áreas de exposições em Brasília soma. $57.400 m^{2}$. Já a oferta global de assentos é de 38.827, o que mostra uma taxa de ocupação média anual de 56,55\%. A média de participantes por evento, em Brasília, é de 283 pessoas. Considerando-se o número total de 7.293 eventos anuais nesta cidade, chega-se a um montante de 2.063.919 participantes de eventos. Segundo distribuição indicada pelas empresas organizadoras de eventos estes participantes dividem-se em $67,2 \%$ de residentes na cidade do evento e $32,8 \%$ de visitantes na cidade. Considerando-se, ainda, que as organizadoras de eventos indicam um gasto médio de $\mathrm{R} \$ 50,00$ por dia para os participantes residentes na cidade e de $\mathrm{R} \$ 320,00$ por dia por visitante e considerando-se, também que os visitantes locais permanecem cerca de 1,5 dia no evento e os visitantes 2,6 dias no evento, pode-se estimar o montante de gastos dos participantes de eventos de Brasília. Os gastos dos participantes com o custo global de organização somam um faturamento total de $\mathrm{R} \$ 1.037 .556 .075,00$.

É importante que os gestores trabalhem de forma a fazer com que os benefícios econômicos advindos dessas atividades possam alcançar a sociedade como um todo. Negligenciar os investimentos em infra-estrutura básica como pavimentação, iluminação pública, saneamento, saúde acarreta à perda do principal parceiro, a população local. Da mesma forma não pode ser feito apenas em época de alta temporada. Do contrário, os eventos passam a ser divulgadores das deficiências da localidade. Resultado: Marketing Negativo. A fidelidade ao conceito e proposta de um plano de marketing responsável garante a maximização dos resultados positivos dados por meio dos eventos. Possibilita à localidade um lugar de destaque e uma imagem positiva.

\subsubsection{Eventos como Estratégia de Marketing para o Turismo}


O evento é uma ferramenta de comunicação que se destaca dentro da atividade empresarial. Capaz de estreitar as relações entre as organizações e seus públicos de interesse, se destaca como uma ação concreta e de permanentes resultados benéficos.

O desenvolvimento constante e gradual da atividade turística, bem como a expansão de seus produtos, tanto em nível nacional como internacional, gera um contexto comum a todas as localidades onde o consumo é crescente. O que justifica a ação do marketing turístico.

O despertar da vocação turística, geralmente, implica o fato de a localidade estar defasada em sua economia e socialmente instável. O turismo vem de forma a preencher essas lacunas de maneira positiva, gerando empregos e divisas, movimentando a economia e otimizando o uso dos equipamentos e serviços do local.

O evento constitui-se desta forma, um mix de ações promocionais com o objetivo de atingir um determinado público alvo, divulgando uma marca ou um produto, promovendo e potencializando suas vendas e abrindo novos mercados. Através de um evento se possibilita a participação de patrocinadores e uma interação com o público de interesse. Pode contribuir para o bem-estar social e nas melhorias da comunidade ao redor.

"Se desejarmos que os eventos sejam eficazes na tarefa de posicionar seus locais de destino no mercado, eles devem buscar a autenticidade e a expressão das características únicas de suas comunidades. Os visitantes desejam fazer aquilo que os residentes fazem, e vivenciar as coisas de sua preferência nos destinos". (ALLEN ET AL: 2003; 12).

O desenvolvimento anual de festivais regionais procura recriarem os ambientes de cada região, possibilitando a vivencia dos costumes a particularidade da cada canto no país.

\subsubsection{Impactos Físicos e Ambientais}

Os eventos, de forma geral, têm como característica gerar um impacto sociocultural direto em seus participantes individualmente e, até, na própria comunidade local, conforme descrito por HALL (1989) e GETZ (1997) apud ALLEN ET AL (2003; 12). Para ilustrar essa relação, pode-se citar a experiência compartilhada e entretenimento em um evento esportivo ou um conserto. Dentre outros impactos, alguns eventos propiciam um legado de maior conscientização e participação em atividades esporti- 
vas e culturais específicas. Outros ampliam os horizontes culturais do povo, expondo-o a pessoas, costumes ou idéias desafiadoras, alguns geram patriotismo.

"Os pesquisadores indicam que as comunidades locais sempre dão valor aos aspectos de 'curtição' dos eventos de grife, e estão preparadas para suportar o desconforto e agitação temporários em vista da intensa emoção que eles geram, bem como da expectativa da melhora das instalações e do perfil no longo prazo". (ALLEN ET AL: 2003; 12).

Um estudo feito por SOUTAR e MCLEOD (1989), apud ALLEN ET AL (2003; 12), acerca das opiniões dos habitantes de Fremantle quanto à America's Cup, constatou-se que a população local, desejosos que a cidade fosse sede de outra America's Cupou ou de outros eventos futuros, percebia o evento como responsável pela meIhoria da qualidade de vida de Fremantle.

\title{
2.4.6. Impactos Políticos
}

Os eventos estão diretamente ligados ao meio político. Nesse sentido, essa relação pode estabelecer uma dependência, mesmo que momentânea, que alterna entre as duas vias.

"As políticas e os políticos são uma importante parcela da equação que é hoje o geren-
ciamento de eventos. Desde que os imperadores romanos descobriram o poder o po-
der do circo para se desviar das críticas e reforçar a popularidade, políticos perspicazes
têm abraçado a realização de eventos, assegurando a satisfação do público e o seu lu-
gar no poder". (ALLEN ET AL: 2003; 16). O Conde Nicolau Maquiavel, conselheiro dos Médicis no século XVI, tinha a seguinte opinião:

\begin{abstract}
“Um príncipe também deve se mostrar admirador do mérito, promover aqueles que são capazes e honrar os que são bons em qualquer arte... Além disso, ele deve, em estações do ano convenientes, manter as pessoas ocupadas com festivais e eventos; e como cada cidade está dividida em agremiações e classes, ele deve atentar para todos esses grupos, confraternizar com eles de tempos em tempos, e dar a eles um exemplo de sua benevolência e generosidade, sempre mantendo, no entanto, a majestade de sua dignidade, que jamais deverá ser admitida como falível em qualquer área". (ALLEN ET AL: 2003; 16).
\end{abstract}

No que trata da dependência política em relação aos eventos, se dá o fato de ajudarem na manutenção do bem-estar e saúde social. Uma vez que oferecem lazer, informação ou entretenimento de uma forma geral. Em outros casos, podem ser usados como instrumento apaziguador em tempos de crise ou, até mesmo, de maneira a manipular a opinião pública. Contudo, este estudo não pretende discutir as implicações éticas da utilização da promoção de eventos por políticos, mas a sua influência nessa área. 
Outra função predominante no uso dos eventos pelos políticos é a sua capacidade de atrair atenção das mídias. Dessa forma, as ações, a postura, e a até a ideologia dos governos podem ser divulgadas de maneira subjetiva através desses acontecimentos

\begin{abstract}
"Os governos continuarão a usar os eventos de marca para destacar seus finais de períodos no poder, para aumentar o nacionalismo, o entusiasmo e, finalmente, os votos... Neste sentido, os eventos de marca não escondem realidades políticas, mas são de fato a realidade política". (ARNOLD ET AL:1989), apud (ALLEN ET AL: 2003; 17).

"A política tem importância crucial em eventos de marca. Seria ingenuidade ou falsidade fazer de conta que isso não acontece. Os eventos alteram a estrutura temporal na qual o planejamento ocorre e se transformam em oportunidades para fazer algo inovador e melhor do que antes. Nesse contexto, os eventos podem alterar ou legitimar (sic) prioridades políticas no curto prazo e ideologias políticas e realidades socioculturais no longo prazo. Eventos de marca representam os torneios dos antigos, preenchendo necessidades psicológicas e políticas através da conquista do direito de ser a sede em relação a outras localidades e de triunfar nos próprios eventos. Após um evento de marca, alguns lugares jamais serão os mesmos novamente, quer física, econômica, social $e$, talvez mais importante ainda, politicamente". (ARNOLD ET AL:1989), apud (ALLEN ET AL: 2003; 17).
\end{abstract}

Há uma percepção global dos governos sobre a capacidade dos eventos de enriquecer e melhorar o perfil e a imagem dos políticos e das cidades e estados quem governam. Pois atraem visitantes, geram benefícios econômicos, empregos, mais impostos. Essa combinação mobiliza os governos a se tornarem os participantes mais importantes na proposta, recepção e produção de eventos de grande porte de maneira a vincularem diretamente seus objetivos.

\title{
2.4.7. Turismo e Impactos Econômicos
}

"O turismo é, cada vez mais, ferramenta utilizada pelos governos, pois se trata de uma indústria em crescimento capaz de produzir benefícios econômicos e gerar empregos. Os eventos atraem visitantes, onde o aumento do de gastos médios por turista é substancialmente maior, bem como seu período de permanência. Trabalhados corretamente são extremamente importantes como formadores de imagens, criando um perfil para os destinos, posicionando-os no mercado e fornecendo-lhes uma vantagem competitiva de marketing". (ALLEN ET AL: 2003; 16).

Os eventos vêm demonstrando sua força na divulgação de produtos turísticos e na promoção de ações estratégicas de desenvolvimento, consolidando espaço definitivo no turismo e, por sua vez, no cenário socioeconômico mundial. 
Segundo informações obtidas no I Dimensionamento Econômico da Indústria de Eventos no Brasil, publicado pelo SEBRAE em parceria com o Fórum Brasileiro Convention \& Visitors Bureau, nos anos de 2001-2002, acontecem anualmente no país mais de 330 mil eventos, envolvendo 79,9 milhões de participantes. Somando-se os gastos dos participantes, a receita das locações e das empresas organizadoras, chega-se a uma renda total de $\mathrm{R} \$ 37$ bilhões por ano, o que representa 3,1\% do PIB brasileiro. Em termos de geração de empregos, a indústria de eventos responde anualmente por cerca de três milhões de empregos diretos, terceirizados e indiretos. A arrecadação de tributos gerada é estimada em $\mathrm{R} \$ 4,2$ bilhões.

O turismo de eventos, segundo esse estudo, é responsável por grande parte dos fluxos turísticos para os destinos brasileiros. Na década de 90, o número de turistas que entrou no Brasil com a finalidade de participar dos mais variados eventos oscilou entre 34 e 71 mil pessoas. A média de permanência destas pessoas é de 2,6 dias, com um gasto diário de $\mathrm{R} \$ 392,05$. Vale ressaltar, ainda, que 52\% destes eventos foram realizados na região Sudeste. O impacto gerado por esta promissora indústria do turismo de eventos no país proporciona gastos diretos no valor de US\$ 981,4 milhões, gerando 33,8 mil empregos diretos e US\$ 108,3 milhões em impostos.

Essa indústria tem um papel significativo no estimulo para o desenvolvimento das micro e pequenas empresas, responsáveis por cerca de 90\% do total de empresas brasileiras, com 94\% de atuação no setor de serviços exercendo relevante papel na área de terceirização. Como gerados de empregos, esse setor contrata, em média, 6,8 funcionários fixos. Este número multiplicado pelos 1.780 espaços, resulta em 12.104 postos de trabalho diretos, aos quais deve-se acrescentar 58.240 empregos terceirizados. As empresas organizadoras contratam em média 24,2 empregados fixos e 386,6 terceirizados. Considerando apenas o universo de 400 empresas e entidades que constam desta pesquisa, o número de empregos chega a 164.320 diretos e 492.960 terceirizados, num total de 657.280 .

Ainda nesse embate, segundo dados divulgados no Relatório da EMBRATUR de estudos de demanda turística (Brasília; 1998), um turista de eventos chega gastar até três vezes mais do que um turista convencional de férias, permanecendo, em média, por um período de 02 a 05 dias na cidade. "Para o participante de um evento bem sucedido, a imagem que fica é o amálgama da experiência positiva, gerando o 
sentido de satisfação e a vontade de repetir a experiência" disse Aristides de La Plata Cury, Diretor Executivo do São Paulo C\&VB, em maio de 2001. Uma outra evidência desta relação é a criação dos Convention \& Visitors Bureau em diversas cidades do país. Ao todo, podemos citar mais de 30 já constituídos, além de outros em fase de implantação.

\title{
2.4.8. Eventos e Sazonalidade
}

Sendo uma das atividades econômicas que mais cresce no mundo, o turismo está sujeito a uma série de condicionantes, variáveis que o influenciam diretamente. Essas influências podem trazer consigo o problema da sazonalidade que, MOTA (2003;20), apud ALBUQUERQUE (2004; 26), define como um fenômeno decorrente da concentração das atividades turísticas no espaço e no tempo.

\begin{abstract}
"A sazonalidade é um dos principais problemas da "indústria turística". No período de alta temporada produzem-se fenômenos de saturação como congestionamentos em estradas, carência no abastecimento de água e energia elétrica, falta de rede de esgoto, aumento da poluição das águas e ruídos, ao contrário do período de baixa estação, quando muitas empresas são obrigadas a fechar por falta de demanda, causando desemprego à população local. A sazonalidade é conseqüência do turismo de massa, o que caracteriza a atividade turística nas regiões litorâneas. Existem dois tipos de sazonalidade: a de demanda e a da oferta. Contra a primeira pode-se lutar por meio de medidas para evitar estas grandes concentrações de veraneio e repartir a demanda no decorrer do ano. Tais medidas podem ser: incentivar os trabalhadores a tirar férias em períodos fora do verão, oferecendo preços mais atraentes, promoção do turismo social ou de outros tipos de turismo que não estejam condicionados ao clima. A sazonalidade da oferta (dos recursos naturais) é mais difícil de superar, visto que não se pode lutar contra o clima. Certas medidas poderão minimizar o problema, como a criação de novos produtos que não tenham o clima como fator determinante". (NERI: 2003), apud (ALBUQUERQUE: 2004; 26).

"A ocupação dos equipamentos turísticos em baixas estações é vantajosa tanto para empresários quanto para os próprios turistas". (IGNARRA: 1999; 195), apud (ALBYQUERQUE: 2004; 27).
\end{abstract}

Uma grande vantagem do turismo de eventos é poder atrair visitantes durante a baixa temporada, quando as companhias aéreas e acomodações geralmente estão operando com capacidade ociosa. Uma das preocupações desse trabalho.

"O turismo de eventos é também conhecido como o turismo de baixa estação por ser responsável por manter em movimento as atividades no setor durante os meses em que o turismo de lazer é mais fraco, gerando grandes valores, uma vez que os turistas de eventos geralmente dispõem de mais recursos financeiros nas viagens". (ALBUQUERQUE: 2004; 27).

A tentativa de reduzir a sazonalidade deve ser uma preocupação da gestão turística. A estratégia de complementação dos atrativos da alta estação, com outras atrações que criam demanda durante o período de baixa temporada é uma forma. A criação de uma agenda anual e a priorização de eventos como os "Encontros Regionais", 
proposta, visa exatamente à viabilização de eventos para reduzir a sazonalidade de Brasília, principalmente durante os finais de semana.

Os eventos possibilitam mobilizar a estrutura de toda uma cidade, começando pelo poder público, que deve colocar em prática uma série de medidas de melhoria de infra-estrutura que vão possibilitar que uma cidade sedie um evento, mas que depois são aproveitadas em benefício da comunidade. Toda a rede hoteleira e alimentícia é beneficiada a partir disso.

\subsection{Posicionamento/ Destinação Turística/ Relevância da Imagem}

Apesar desse tema não ser profundamente estudado, é de grande relevância. Fazse necessário destacá-lo em virtude da proposta desse projeto.

Atualmente, o número de turistas estrangeiros que visitam o Brasil anualmente está muito abaixo da meta estabelecida pela EMBRATUR. O mesmo caso se aplica à Brasília, capital do país.

As destinações procuram adotar diferenciais competitivos e apelar para fatores primordiais, como: infra-estrutura básica, turística e de atrativos. Contudo, negligenciam a importância de trabalhar a sua 'imagem', bem como sua manutenção. Dessa forma, os fatores negativos acabam multiplicados pela imprensa brasileira, sem que haja o desenvolvimento de um relacionamento com estes órgãos no sentido de minimizar a divulgação negativa, que muitas vezes são apenas citados nas manchetes pelo fato de terem ocorrido na localidade, ou seja, na capital.

\subsubsection{Posicionamento}

A Americam Marketing Association (AMA) define marca como 'um nome, termo, sinal, símbolo ou design, ou uma combinação de tudo isso, destinado a identificar os produtos ou serviços de um fornecedor ou grupo de fornecedores para diferenciá-los dos outros concorrentes'. A marca é, nesse sentido, um produto ou serviço que agrega dimensões que diferenciam de outros produtos ou serviço desenvolvidos para satisfazer a mesma necessidade, mais ligado à idéia abstrata de satisfações psicológicas e não físicas. Podendo ser diferenças funcionais, racionais ou tangíveis relacionadas ao desempenho do produto, enquanto podem também ser mais simbólicas, emocionais ou intangíveis - relacionadas ao que a marca representa. 
A necessidade de recriar a marca Brasília, uma vez que essa é conciliada por alguns setores da imprensa à corrupção e a lugar de pessoas desonestas, devido a alguns escândalos políticos, exige o conhecimento desse conceito.

"é a ação de projetar o produto e a imagem da empresa para ocupar um lugar diferenciado na mente do público-alvo. O objetivo é posicionar a marca na mente dos consumidores a fim de maximizar a vantagem potencial da empresa". (KOTLER e KELLER : 2007; 305).

Dessa forma, pode-se trabalhar o posicionamento da marca Brasília, fomentando seus aspetos positivos e criando um vinculo de valores á sua natureza como capital cultural.

"O posicionamento é um elemento chave para a estratégia de marketing competitivo e tem sido definido como sendo o ato de projetar uma imagem da oferta da empresa de forma que os clientes compreendam e apreciem o que o produto representa em relação aos concorrentes". (KOHLI e LEUTHESSER: 1993), apud (KOTLER \& KELLER: 2007; 267).

Para tornar a cidade uma destinação turística é necessário um forte trabalho de marketing que busque consolidar sua imagem de forma positiva.

\subsubsection{O que é uma 'Marca' e como funciona o 'Branding'}

Criar, manter, aprimorar e proteger as marcas é um processo na estratégia de Marketing que deve ser embasado em cima de uma análise criteriosa acerca da necessidade do público desejado.

A construção de uma marca forte requer um cuidadoso planejamento e gigantescos investimentos no longo prazo. Na essência de uma marca bem sucedida existe um excelente produto ou serviço, sustentado por um marketing desenvolvido e executado com criatividade. (KOTLER \& KELLER: 2007; 268).

O branding, que representa o patrimônio da marca e que acopla todo esse processo, se tornou uma prioridade para as empresas desejam se sobressair no processo de gerenciamento estratégico da marca, estes compreendem quatro etapas principais, como:

- Identificação e definição do posicionamento da marca;

- Planejamento e implantação do marketing da marca;

- Avaliação e interpretação do desenvolvimento da marca;

- Crescimento e sustentação do valor da marca.

Para colocar uma marca em um produto ou serviço, é necessário 'ensinar' os aos consumidores 'quem' é o produto, batizando-o e utilizando outros elementos de marca que ajudem a identificá-lo, bem como a 'que' ele se presta e 'porque' o consumidor deve se interessar por ele. (KOTLER \& KELLER: 2007; 269).

A correta utilização do branding possibilita tornar uma ferramenta eficaz na obtenção de vantagem competitiva. Mesmo porque cria estruturas mentais e ajuda o consumidor a organizar seu conhecimento sobre produtos e serviços através da capacidade 
da ligação entre marca e qualidade. É necessário que, dessa forma, sejam criadas diferenças significativas entre as marcas e uma categoria de produto (Brasília) ou serviço de forma a convencer os consumidores, de modo a agregar valor à marca dando origem ao que é denominado 'brand equipy'.

O branding pode ser aplicado em qualquer campo no qual o consumidor tenha opção, sendo assim, a um local, como a cidade de Brasília, estado do Texas ou o país com a Espanha.

\subsubsection{Destinação Turística}

A demanda de turismo é um processo de consumo influenciado por diversos fatores. Sendo, desta forma, passível de estudos que possam delinear suas necessidades e variações. Essas condicionantes podem estar ligadas a variáveis, das quais, tornase fundamental o estudo.

\subsubsection{Processo de Escolha}

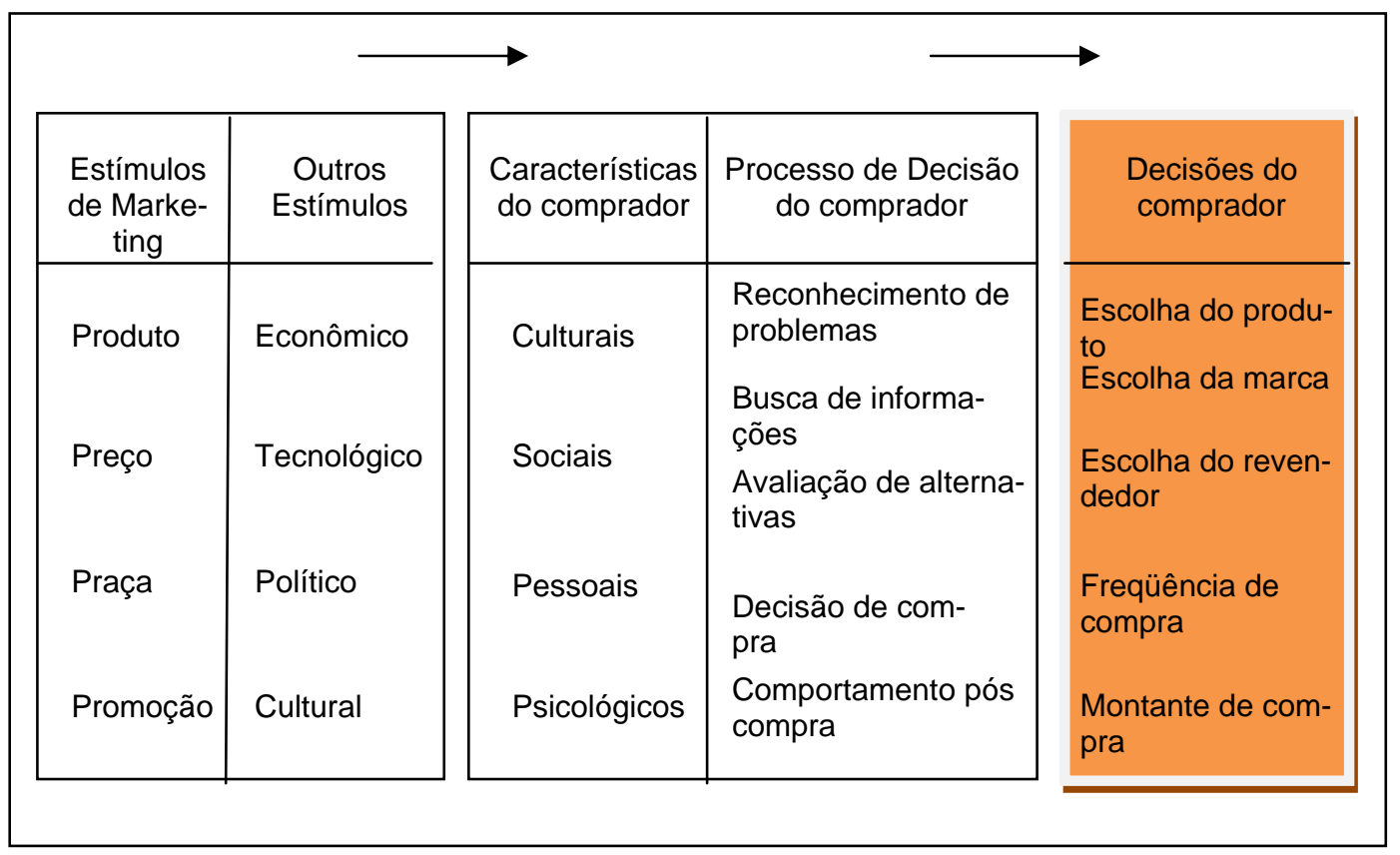

Figura 1.1 Modelo de estímulo e resposta (KOTLER: 2002; 162).

O modelo de estímulo e resposta de KOTLER (2002; 162), é o passo inicial para compreender o comportamento do consumidor (turista). Pois indica que estímulos ambientais e de marketing penetram no consciente do mesmo. Suas características e processos de decisão levam a certas decisões de compra. A tarefa do profissional de marketing consiste em estudar e atender o que acontece no consciente do con- 
sumidor entre a chegada do estímulo externo e a decisão de compra, buscando dessa maneira gerar um produto ou imagem a partir do que este deseja.

\subsubsection{Fundamentos e Comportamento do Consumidor}

O processo de decisão do consumidor é outro fator relevante na construção eficaz do planejamento de marketing, aqui foi adotado o sistema formulado por COOPER ET AL (2001; 63), apud TOMIKAWA: 2004; 38), que aponta os quatro elementos básicos:

1. Energizadores de demanda: são as forças de motivação que levam um turista a decidir visitar uma atração ou sair de férias.

2. Efetivadores de demanda: o consumidor terá desenvolvido idéias a respeito de uma destinação, um produto ou organização, por meio de um processo de aprendizagem, atitudes e associações, a partir de mensagens promocionais e informação. Isso afetará a imagem do consumidor e o conhecimento de um produto turístico, servindo assim para elevar ou diminuir os vários energizadores que levam à ação do consumidor.

3. Os papéis e o processo de decisão: o papel importante é aquele do membro da família que está normalmente envolvido nos diferentes estágios do processo de aquisição e na resolução final das decisões sobre quando, onde e como o grupo irá consumir o produto turístico.

4. Determinantes da demanda: o processo de tomada de decisões do consumidor de turismo é sustentado pelos determinantes da demanda. Ainda que possa haver motivação, a demanda é filtrada, limitada e canalizada devido a fatores econômicos (renda), sociológicos (grupos de referência, valores culturais, religiosos) ou psicológicos (percepção de risco, personalidade, atitudes).

Esses elementos são simplificados no quadro a seguir:

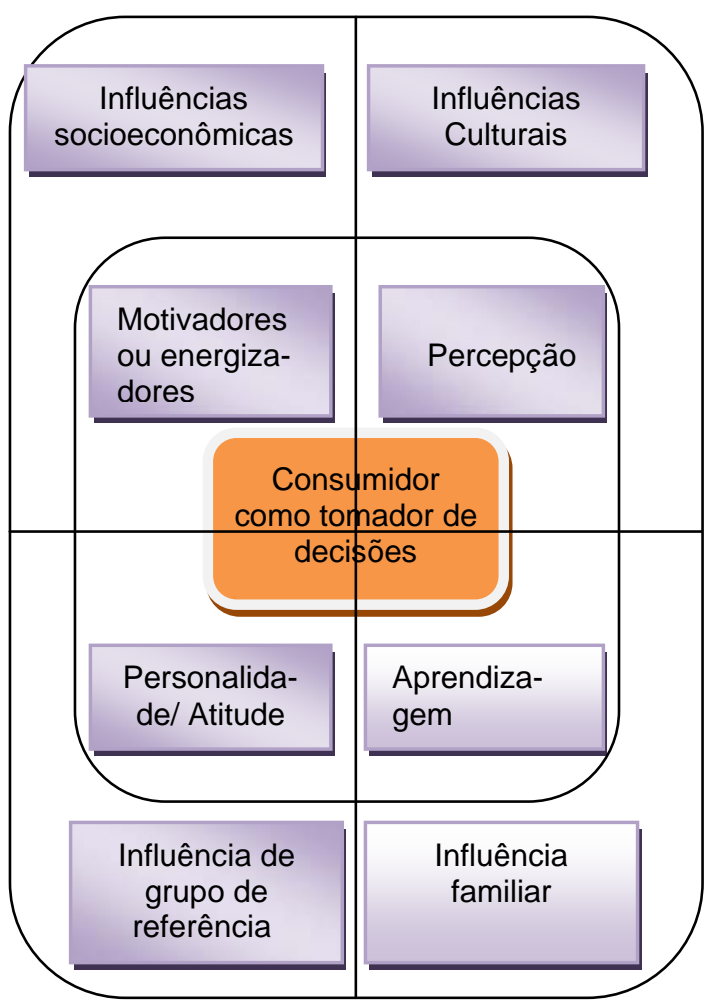


Figura 1.2 Processo de decisão do consumidor em turismo

(COOPER ET AL: 2001).

\subsubsection{Energizadores e Efetivadores}

\subsection{Motivação}

Significa fazer uma pessoa agir de uma certa maneira, ou estimular o seu interesse. Motivo também está relacionado com iniciar um movimento ou induzir uma pessoa a agir. Para o turismo, a motivação é o ponto de partida do processo de consumo de um produto turístico. Daí a necessidade de ser estudada

\subsection{A hierarquia das necessidades de Maslow}

A hierarquia das necessidades de Maslow talvez seja a mais conhecida teoria da motivação. Em resumo, ele sugeriu que as necessidades humanas como elementos motivadores formam uma hierarquia.

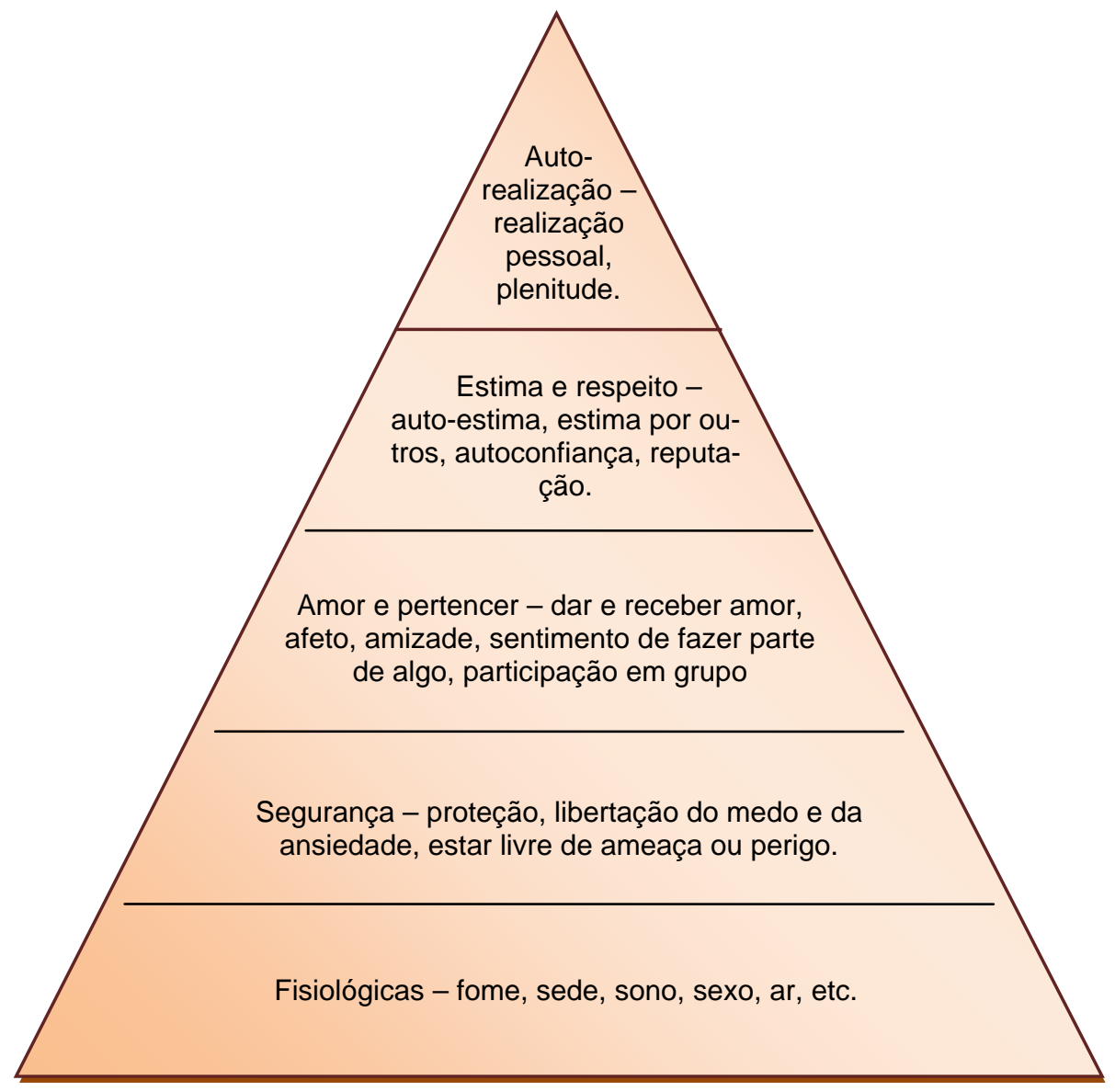

Figura 1.3 Hierarquia das necessidades. Adaptação de MASLOW (1943).

\subsection{A Importância da Imagem}

A visão que se tem do mundo é feita de experiências, aprendizados, emoções e percepções ou, mais precisamente, da avaliação cognitiva dos elementos citados acima. Essa visão poder ser descrita como conhecimento, produzindo uma imagem específica do mundo. 
A imagem é de importância fundamental para a preferência, a motivação e o comportamento de um indivíduo com relação a produtos e destinações turísticas, já que irá fornecer um efeito "impulso" que resultará em diferentes prognósticos de demanda.

o comportamento turístico, tanto de indivíduos como de grupos, depende de sua imagem sobre situações imediatas e do mundo. A noção de imagem está intimamente relacionada ao comportamento e à atitude os quais são estabelecidos com base na imagem presumida de uma pessoa e não mudam facilmente, a não ser que nova informação ou experiência seja adquirida.

\subsection{Determinantes da Demanda}

Uma vez tomada a decisão de viajar, a capacidade de fazer a viagem e a natureza da viagem serão determinadas por um amplo leque de fatores inter-relacionados. Esses fatores podem ser divididos, de forma ampla, em dois grupos: estilo de vida e ciclo de vida.

\subsubsection{Imagem da Destinação Turística}

Para a psicologia, a definição "imagem" está relacionada à representação visual. Já do ponto de vista do marketing, trata-se do posicionamento do produto e o comportamento do consumidor ou grupo de consumidores em relação ao ele.

A definição de imagem de uma destinação turística mais comum é "a soma de crenças, idéias e impressões que uma pessoa tem de uma destinação" (CROMPTON: 1979), apud JENKINS (1999), apud TOMIKAWA (2004; 40). No entanto, é baseada no indivíduo, apropriando-se dos aspectos da imagem partilhada por grupos, os estereótipos, muito importantes para os estudos de mercado.

"a imagem da destinação turística é um fator crítico no processo de escolha do turista. Ela influencia a escolha de qual local visitar, o comportamento do turista na destinação, o nível de satisfação e as lembranças da experiência. Ou seja, ela está presente em toda experiência de consumo, desde o estímulo, a satisfação até o pós-venda (sic). Por isso, uma análise detalhada de como a imagem é formada e das técnicas de mensuração disponíveis fazem-se necessárias na medida em que podem ajudar os planejadores da indústria turística a tomarem decisões que aumentem o fluxo de turistas e atendam as suas necessidades". MAYO (1975; 15) apud TOMIKAWA (2004; 40),

Uma vez que se pretende fomentar o turismo em Brasília e posicionar seu nome em lugar de destaque no cenário nacional de maneira positiva. Tal definição capta a essência dessa intenção.

\subsubsection{Formação da Imagem}

Vários pesquisadores têm investigado os fatores influentes na formação da imagem. Dentre esses fatores, estudos de HUNT (1975) e de SCOTT ET AL: (1978) apud TOMIKAWA: 2004; 42), indicam que a distância da destinação em relação ao local de origem do turista influencia a formação da imagem, uma vez que, por diversos fatores, as pessoas estão mais condicionadas a visitarem destinações mais próximas de onde residem e mais expostas a informações sobre elas pela mídia e pelos 
amigos e parentes. Assim, têm imagens mais realistas das destinações próximas a seu local de origem.

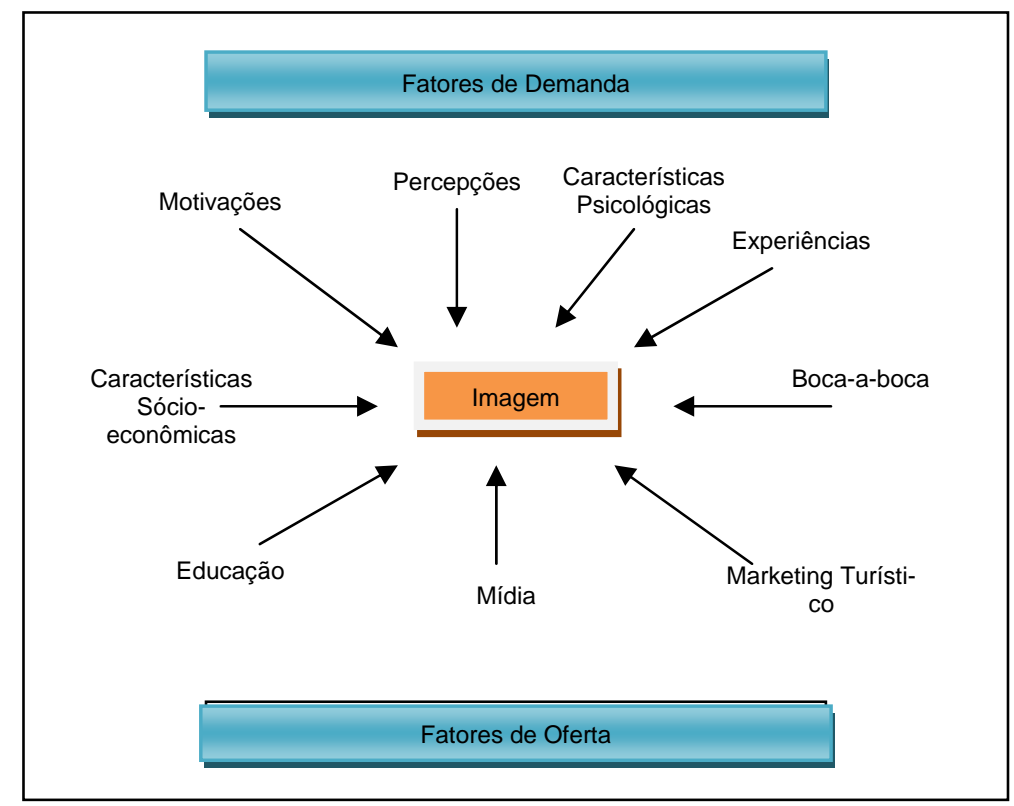

Figura 2.5.3.1.a - Fatores de influência na formação da imagem turística pelos consumidores

(STABLER: 1988), apud TOMIKAWA (2004; 42).

As estatísticas apontadas pela a Embratur validam essa realidade, onde a maioria dos turistas que vêm ao Brasil é dos EUA e da Argentina, locais mais próximos que a Europa ou Ásia, por exemplo.

$\mathrm{Na}$ intenção de identificar outros fatores formadores de imagem pesquisando as fontes de informações, NOLAN (1976), apud TOMIKAWA (2004; 43), descobriram que os turistas domésticos nos EUA, na maioria dos casos, usam a indicação de amigos e parentes, seguida de guias de viagem, informações comerciais do trade turístico e depois publicações promocionais. Já no que condiz à credibilidade das fontes de informações de viagem, os guias foram classificados em primeiro, enquanto os serviços disponibilizados pelo governo e o conselho de amigos e parentes foram considerados mais informativos. O autor também mediu o "propósito" das fontes de informações de viagem, pedindo para os entrevistados que classificassem se as fontes eram tendenciosas/não-tendenciosas, e inferiu pelos resultados que a comunicação das informações de viagem (em especial os folhetos de viagem) é tendenciosa.

Investigando as imagens que turistas regionais tinham dos National Parks na América do Norte, MAYO (1975), apud (TOMIKAWA: 2004; 46), descreve 3 componentes básicos: cenário, congestionamento e clima. O autor foca suas dimensões nos aspecto físico/funcional da destinação que são observadas diretamente e facilmente 
mensuráveis como preço e temperatura do local, aspectos levantados pela maioria dos autores.

Os estudos que se preocupam com os aspectos menos tangíveis são raros, contudo, a análise desses aspectos foi uma preocupação ECHTNER e RITCHIE (1991), apud (TOMIKAWA: 2004; 47). O componente comum/único é outra grande variável que diferencia seu trabalho dos outros autores, já que foi negligenciado na maior parte dos estudos sobre imagem, mesmo pela a facilidade de sua percepção que consiste identificar que algumas características das destinações são comuns entre elas e outras são únicas, próprias.

ECHTNER e RITCHIE (1991), apud (TOMIKAWA: 2004; 46), identificaram três dimensões básicas da imagem de destinações:

Atributos-Holístico: Atributos estão relacionados às características específicas de uma destinação. Holístico relaciona-se à impressão total, geral que o turista tem a seu respeito. Ambos podem variar desde o âmbito funcional até o psicológico.

Funcional-Psicológico: A discussão sobre essa dimensão gira em torno de características e impressões tangíveis (ex: atrativos turísticos, acomodações, etc.) e abstratas (ex: hospitalidade, tranqüilidade, sentimentos religiosos, etc.). Elas podem ser comuns ou únicas.

Comum-Único: A terceira dimensão exposta relaciona-se a impressões e características que são freqüentemente encontradas e aquelas que são peculiares a algumas destinações.

A partir do cruzamento dessas dimensões é gerada a imagem percebida da destinação. Por exemplo, atributos funcionais comuns são aqueles de fácil comparação entre as destinações, como preço, temperatura, tipos de acomodação. Atributos funcionais únicos são os símbolos e eventos especiais que fazem parte da destinação, como o Cristo Redentor no Rio de Janeiro e o Festival de Parintins no Amazonas. Já os atributos psicológicos comuns consistem na hospitalidade da população local, na notoriedade ou beleza de uma paisagem, enquanto os atributos psicológicos únicos incluem os sentimentos associados à peregrinação religiosa, como a visitação da Basílica de Aparecida do Norte ou lugares associados a eventos históricos, como Ouro Preto e Tiradentes em Minas Gerais.

De uma forma geral, Brasília conta com todos os aspectos possíveis para se construir uma imagem positiva e torná-la uma destinação turística de proporções internacionais.

\subsubsection{A Imagem do Brasil no Exterior}


A Confederação Nacional do Transporte (CNT) em 2001 encomendou, pela primeira vez, uma pesquisa com o objetivo de identificar a percepção do mundo em relação ao Brasil. A pesquisa foi realizada em 22 países entre eles os Estados Unidos, Japão, Inglaterra e África do Sul e foi coordenada pelo Instituto Sensus, com apoio da Universidade de Michigan, nos EUA. Constatou-se:

- O Brasil e seu povo continuam sendo conhecidos no mundo por suas praias, futebol, alegria e cordialidade aspectos que há muito traçam o perfil do país no exterior;

- Os produtos de exportação mais conhecidos ainda são o café e a banana. Para $58,2 \%$ dos entrevistados, o café é o principal produto de exportação quando, um forte contraste com a realidade, onde,na verdade, o café só representa $3 \%$ da pauta brasileira de exportações;

- O futebol é a imagem mais associada ao país é o futebol apontado por $36,6 \%$ dos entrevistados e o carnaval por $19,4 \%$ dos ouvidos.

- Em relação à localização do país no mapa geográfico, 75\% dos entrevistados souberam dizer que o Brasil se encontra na América do Sul;

- As praias, o clima e a natureza são os fatores que mais motivam aqueles que disserem ter vontade de conhecer o país;

- O brasileiro mais ilustre no exterior ainda é o Pelé, seguido do jogador Ronaldinho fenômeno e do falecido piloto Ayrton Senna; 


\section{MÉTODOS E TÉCNICAS DE PESQUISA}

De acordo com Gil (1991), pesquisa pode ser definida como um processo coerente, lógico e sistemático que tem por objetivo proporcionar respostas aos questionamentos propostos. Dessa forma, é desenvolvida de forma racional, mediante a afluência dos conhecimentos disponíveis e a utilização cautelosa de métodos, técnicas e demais procedimentos científicos. É composta por várias etapas, desde o desenvolvimento dos questionamentos, até a apresentação dos resultados.

Como toda atividade racional e sistemática, a pesquisa precisa que as ações a serem desenvolvidas ao longo de seu processo sejam efetivamente planejadas. Gil (1991) define o planejamento da pesquisa como o decurso de uma ação continuada sistematizada, por meio da qual pode-se conferir maior eficiência à investigação, para em determinado prazo atingir a totalidade dos objetivos estabelecidos.

A pesquisa é caracterizada, dessa forma, como uma ferramenta para adquirir conhecimentos. Sua credibilidade reside na utilização do método científico, que entre outros aspectos, supõe que para se estudar um fenômeno cientificamente, este deverá ser medido, ou seja, o evento deverá ser perceptível, sensível e classificável, ainda que o cientista trabalhe com conceitos abstratos. Este processo reflete a confiança na capacidade de percepção e observação do pesquisador. (RICHARDSON, 1985).

Toda e qualquer classificação se faz mediante algum critério. Gil (1991) afirma que no caso das pesquisas, é recorrente a classificação com base em seus objetivos gerais. Dessa forma, é possível organizá-las em três grandes grupos: exploratórias, descritivas e explicativas. A primeira classe refere-se a trabalhos que buscam familiaridade com um fenômeno pouco estudado, com vista a torná-lo mais explícito ou construir hipóteses. As pesquisas descritivas têm por meta primordial a descrição das características de determinada população ou evento, com possível estabelecimento de relação entre as variáveis. O último grupo corresponde a estudos que tem como preocupação central a identificação de fatores que determinam ou que contribuem para a ocorrência de fenômenos.

A presente investigação classifica-se como pesquisa explicativa, pois busca explicitar, de maneira coerente, os aspectos que dizem respeito ao fenômeno turístico em Brasília e a contribuição que é gerada através da promoção e produção de 
eventos, em especial os 'Encontros Regionais', uma vez que se pode relacionar a sua interdependência tornar menos complexo o processo de identificar suas determinantes.

Sobre o critério fontes de informação, Gil (1991), delimita duas classes: pesquisas cujas fontes limitam-se a material já escrito sobre o assunto, e aquelas na qual as informações são obtidas in loco. Embora possua levantamento de material teórico, livros e artigos científicos, esta pesquisa não será desenvolvida exclusivamente com base em pesquisa bibliográfica, pois também se baseará em informações pragmáticas e empíricas do autor deste trabalho, uma vez que tem vasta experiência na área de eventos.

Para corroborar a utilização de informações dessa natureza, Campomar (1991) indica que a pesquisa em administração pode ser nomeada pesquisa social empírica, uma vez que esta ciência compõe a área social e seus estudos são sobre conhecimentos práticos.

Durante o processo de construção de uma pesquisa, várias são as formas para sua classificação. As modalidades de aplicação da pesquisa podem ser quantitativas, ou qualitativas. Segundo Campomar (1991), o método quantitativo procura encontrar medidas em populações ou amostras com o uso de técnicas estatísticas e testes paramétricos, ou não paramétricos de inferência, ao passo que no qualitativo não há medidas e as possíveis inferências não são estatísticas, mas baseadas em análises em profundidade.

Richardson (1985) caracteriza a técnica quantitativa pelo emprego da quantificação, tanto na coleta de dados quanto no tratamento dos mesmos, por meio de modelos estatísticos, desde os mais simples (percentual, média, desvio-padrão) até os mais complexos (coeficiente de correlação, análise de regressão, variabilidade). Enquanto que a forma quantitativa tem como objeto situações intrincadas ou particulares, e explora as técnicas de observação e entrevista, devido à maneira com que estas penetram na complexidade de um problema. Este estudo caracteriza-se pelo uso do método qualitativo, uma vez que não lançara mão da análise baseada em instrumental estatístico, nem pretende numerar ou quantificar unidades ou categorias homogêneas. 
Portanto, a pesquisa realizada segundo a natureza dos dados é do tipo qualitativa, uma vez que procurou dimensionar os principais aspectos subjetivos extraídos dos respondentes que tinham autoridade para de manifestarem a respeito do tema abordado.

\subsection{Procedimentos e instrumentos utilizados na coleta e análise dos dados}

De acordo com Marconi e Lakatos, (2006) a coleta de dados é a etapa da pesquisa em que se inicia a aplicação dos instrumentos elaborados e das técnicas selecionadas, a fim de se efetuar a coleta dos dados previstos.

De acordo com Richardson (2008) a modalidade de coleta de dados, que combina perguntas fechadas e abertas, oferece ao pesquisador através das perguntas fechadas as informações sociodemográfica do entrevistado (sexo, escolaridade, idade etc.) e respostas de identificação de opiniões (sim - não, conheço - não conheço etc.), e as perguntas abertas, foram destinadas a aprofundar as opiniões do entrevistador.

Partindo desse pressuposto, optou-se por adotar como instrumento de pesquisa para esse projeto, um questionário com perguntas fechadas e abertas com a intenção de identificar o perfil do público e sua opinião a respeito do tema. Nesse sentido, as perguntas fechadas ficaram restritas a dados demográficos, enquanto as questões abertas buscam explorar a visão do entrevistado de forma mais abrangente e convergente com a gama de pensamentos e emoções, que só podem ser identificados através desse tipo de questão. Pois, por se tratar de um tema que transpassa diretamente todos os fatores (racionais, físicos, emocionais, entre outros) que formam a opinião, levando em consideração que se busca mostrar a relação da imagem de Brasília e a sua posição como destinação turística, fez-se necessário esse tipo de exploração.

Os questionários foram aplicados durante a realização do evento 'Encontro do Nordeste', entre pessoas na faixa etária de 18 a 28 anos, de Brasília e Região Nordeste. Nos quatro dias de evento pode-se coletar uma amostra de 100 pessoas em um universo de 100.000 participantes nos quatros dias do evento.

Para determinar o custo fixo dos apartamentos não utilizados nos finais de semana, tendo em vista a proposta gerada no projeto da redução de valores em ocasião dos 
'Encontros Regionais', foi feita uma pesquisa de mercado através do levantamento de tabelas e preços utilizados pela rede hoteleira.

Aos diretores e/ou gerentes e dirigentes de companhias aéreas e hotéis, foram direcionadas entrevistas com perguntas abertas a respeitos de suas opiniões sobre as propostas de tarifas promocionais em decorrência dos Encontros Regionais para serem realizados no ano de 2010.

\subsection{Período de realização da pesquisa}

\section{A pesquisa foi realizada em duas fases:}

A primeira fase, realizada em maio de 2008; e a segunda fase realizada no mês de maio de 2009.

Como fator positivo pode-se destacar a amabilidade da maioria dos respondentes que desde o primeiro contato demonstraram grande interesse e satisfação em participar de uma pesquisa científica que visou investigar a atratividade da festa e o quanto este evento repercutiu no inconsciente coletivo. Não foram poucas as demonstrações de grande satisfação do público entrevistado. Alguns citavam: 'estou matando a saudade da minha região'.

Os depoimentos foram gravados e veiculados no site:

www.brasiliacapitalcultural.com.br, bem como foram anexadas nesta monografia um DVD demonstrativo. 


\section{APRESENTAÇÃO E ANÁLISE DOS DADOS}

\subsection{Agrupamento, Ordenação e Descrição dos Dados}

\subsubsection{Marca}

Verificou-se a importância de reposicionar a marca 'Brasília, uma vez que sinaliza ao turista a origem do 'produto' e suporta, com seus atributos, o conteúdo emocional de imagens que desperta no consumidor (turista) e se constitui numa realidade econômica e social de primordial importância no sistema de economia de mercado e ainda defini como um conjunto de valores.

Considerando-se a forte influência que as marcas e todas as suas associações exercem sobre o comportamento do turista (consumidor), o correto posicionamento do seu conceito na mente dos turistas é fator imprescindível num mercado competitivo. A importância que o turista atribui a um determinado aspecto da cidade (marca), a sua satisfação, enfim, a forma como ele percebe a cidade, podem contribuir fundamentalmente para a formulação de estratégias de posicionamento.

\subsection{2. - Destinação}

É importante ficar atento aos estímulos de marketing proposto por Kotler, os 4 Ps, Produto, Preço, Praça e Promoção. Neste percurso é importante também buscar a adequação de nossa cidade em DESTINO - formando Cluster de Eventos, de Feiras, entre outros, com a participação de todos os envolvidos do trade, para atrair ainda mais o turista.

Outra grande dificuldade encontrada em alguns proprietários de hotéis, é que eles se dão por satisfeito pela grande 'procura' durante os dias da semanas, e entendem que a demanda de seus apartamentos nos finais de semana, que embora sejam poucas, são suficientes pelos preços que empoe aos turistas. Será necessário um trabalho de convencimento para que se abaixem os preços nos finais de semana e promovam ações culturais, que terá como objetivo atrair novos turistas de lazer em todo o Brasil com campanhas específicas e conjuntas com o trade. Outros períodos de finais de semana poderão ser separados para comercialização junto ao Turismo de Negócio (congressos, convenções, encontros, seminários), embora se acredite que muitas vezes, posam ser combinados com um ou mais dos tipos de turismo, como de: Turismo Étnico, Turismo Histórico, Turismo Cultural, Turismo de Lazer, 
Turismo de Esporte, Turismo de Natureza, Turismo Cívico, ou mesmo o Turismo de Negócio e Eventos.

\subsubsection{Posicionamento}

Ao observar os pontos apresentados na análise ambiental, se faz necessária uma tomada de decisão, ou seja, posicionar para que seja mudada a história de Brasília. Em uma delas, por meio de um trabalho junto à imprensa para não mais associar qualquer notícia negativa ou corrupção ao nome de Brasília, mesmo que se tenha que acionar juridicamente os jornalistas que insistirem em veicular nas suas manchetes o nome de Brasília (local) como título das matérias que denotem seu nome. O governo da capital investe grandes somas em campanhas turísticas e não se pode conformar com este desgaste diário, não se pode mais, permitir que o nome de Brasília seja sistematicamente deteriorado pela falta de sensibilidade de alguns profissionais de comunicação. Eles não só trabalham contra a imagem da cidade, mas também promovem uma baixa alta estima no brasileiro, que acabam assimilando a corrupção, à imagem de Brasília, capital de seu país.

Se não vejamos, em recente apresentação de resultados da Brasiliatur, onde reuniu o trade local para apresentação de resultados das pesquisas feitas pelo CET/UnB se verificam, de uma maneira geral, que os resultados são positivos quando o turista rompe as 'barreiras emocionais' e visita a cidade. No segmento turismo de lazer, 93,4\% dos entrevistados responderam que pretendem voltar a Brasília. O índice sobe para 95\% quanto à pergunta é se indicariam a cidade para algum amigo ou parente, ou seja, as pessoas que passam a conhecer Brasília mudam radicalmente suas impressões sobre a mesma.

\subsubsection{Proposição e Reposicionamento}

Portando, estudar a proposta de desenvolver o 'Projeto Brasília Capital Cultural', que é Lei Distrital 3.328/04, nas ações 'Calendário Turístico Cultural de Brasília em 2010' é extremamente oportuno, uma vez que se procura demonstrar a necessidade de Brasília receber grande ocupação hoteleira nos finais de semana, a baixo preço nas diárias de hospedagem e passagens aéreas ou terrestre, uma vez que, é o turista que coloca em movimento todo o sistema, como conseqüência do deslocamento que realiza desde sua região de origem, por meio do caminho até a região de destino, e com o seu posterior regresso. 
Por essas razões, Brasília pode ser identificada como ideal para segmentar o turismo cultural e o de lazer, uma vez que a Capital se encontra no centro de todas as regiões brasileiras, e a população candanga, costuma receber bem as pessoas independentemente da raça, cor, credo, poder aquisitivo, sexo, idade, entre outros.

Numa outra direção, devem-se diminuir sensivelmente os investimentos em propaganda e promoção de vendas locais, antes pulverizados e a partir da segmentação e posicionamento proposto, concentrá-los nas capitais e principais cidades de cada estado brasileiro, de forma inteligente;

Desenvolver proposta e estratégia eficaz de marketing como resposta as essas necessidades, onde se propõe a execução do 'Projeto Brasília Capital Cultural', evento este, que sirva como espaço para o 'lançamento' e a 'prévia' do principal evento cultural que é realizado em cada região brasileira, alem de expor e distribuir a papelaria exibir toda a diversidade de cada estado participante, dessa forma, divulgando estes eventos que são atrativos de turismo e contribuir para a regionalização e fortalecimento dos roteiros turísticos integrados de cada região, bem como, apresentações de eventos inéditos na capital.

\subsubsection{Calendário Turístico Cultural de 2010 em Brasília}

Brasília conseguiu consolidar somente um único evento de atratividade turística, que é o dia 21 de abril, comemoração de seu aniversário, onde grande investimento é disponibilizado para a realização do evento, que vai para a sua quarta edição. Portanto, para se consolidar outras atrações importantes terão que investir grandes somas e gastar muito tempo para que as mesmas sejam conhecidas do turista potencial.

O marketing do 'Projeto Brasília Capital Cultural' prevê realizar previas e lançamentos de grandes eventos, dentre as já existentes no interior, que atraem grande afluência de publico, como:

FESTAS DE SÃO JOÃO, no Encontro do Nordeste, em maio, promovendo uma grande disputa de qual será o melhor Festa São João do Nordeste, entre os nove estados, que poderão apresentar-se, um por dia; 
FESTIVAL FOLCLÓRICO de Parintins / MA, no Encontro do Norte, em junho, uma das mais ricas representações de folclore brasileiro, onde o Caprichoso e o Garantido fazem uma verdadeira competição folclórica, o Bumba Meu Boi;

FESTA DO PEÃO de Barretos / SP no Encontro do Sudeste, em julho, representando uma das manifestações mais antigas da humanidade, a luta entre homem e animal, que atrai inúmeras pessoas do interior;

FESTIVAL INTERNACIONAL DE PESCA ESPORTIVA de Cárceres / MT, no Encontro do Centro-Oeste, em agosto, promovendo e motivando a pesca esportiva em todo país. São mais de mil barcos no rio, pescando, retirando o peixe e repondo após serem pesados e medidos pelo barqueiro, profissional da região; e

OKTOBERFESTAS / SC, no Encontro do Sul, em setembro, em uma das maiores festas gastronômicas do mundo, envolvendo num mesmo período, a divulgação de pelo menos dez cidades de Santa Catarina e umas três cidades do Rio Grande do Sul;

Os outros eventos ou festas da região também serão promovidos nos 'Encontros' com grande destaque, onde será contemplado a muitos artistas e artesãos de expressão regional, para que venham expor e vender seus trabalhos de alto valor agregado.

Saliente-se que, embora todos os 'Encontros Regionais' sejam propostos para serem apresentados em um mesmo local de realização, todos são amplamente diferentes, pois exibem cultura diversa, com características próprias, montagens exclusivas, que serão valorizadas, a fim de que cada um sinta-se prestigiados por sua cultura natal, na Capital do País.

Para mostrar-se no mercado haverá a necessidade de desenvolver o posicionamento para cada segmento no mercado e a estratégia de mix para cada segmento.

Este autor já realizou em maio de 2008 o 'I Encontro do Nordeste', e em maio de 2009 o 'Il Encontro do Nordeste, com a participação de vários prefeitos da região, conforme DVD gravado em anexo.

\subsubsection{Sustentabilidade}

Verificou-se que o Projeto Brasília Capital Cultural é uma oportunidade de reposicionamento da marca Brasília e suas ações contribuem para a ocupação dos finais de semana na capital, bem como é um projeto que se preocupa com a sustentabilidade, 
se não vejamos. Pelo principio da INTREDEPENDÊNCIA o sucesso do evento como todo, dependerá do sucesso de cada estado da federação no evento, uma vez que cada estado se apresentará individualmente no 'Encontro Regional', da mesma forma, que dependerá de cada participante do festival o sucesso do evento como todo, uma vez que será mostrada toda a diversidade sócio turístico cultural de cada região.

Outro padrão da organização do projeto tem a ver com a RECICLAGEM, onde são convidados artesões ecologicamente produtivos e mestre da culinária típica de cada estado a vir participar do projeto, numa ação de 'Comercio Justo', onde não há a intermediação entre eles e a comunidade consumidora no evento. São os 'Artesões' e 'Mestres da Culinária' vendendo diretamente aos visitantes, produtos ecologicamente corretos. Esta modalidade irá desenvolver-se na medida em que o seu cíclico comercial e econômico não interfira na manutenção destas comunidades sustentáveis, como se propõe planejar.

A PARCERIA é a maior característica utilizada no projeto, onde cada integrante passa a entender melhor as necessidades do outros, e juntos, buscam trabalhar e alcançar resultados e objetivos coincidentes, vendendo a região e não somente o estado. O projeto é ecológico uma vez que enfatiza a cooperação, a conservação e a parceria para a realização do evento com amplidão nacional.

FLEXIBILIDADE e DIVERSIDADE são muitíssimo utilizadas no projeto, onde está a maior riqueza de seu conteúdo quando explora inúmeras relações, abordam diferentes costumes, arte popular, gastronomia, artesanato, música e dança de cada região. O brasileiro por essência é um povo flexível quanto à receptividade de outras culturas, bem como, possui uma diversidade turístico, cultural, política e social abundante, receptivo a receber novas interferências culturais e convivê-las com as mesmas em harmonia.

\subsection{Análise descritiva dos dados coletados}

Brasília fruto de uma decisão feliz o ex-presidente, Juscelino Kubistchek, aclamado pelo povo, mas perseguido pelos adversários de Brasília, parece herdar do mesmo destino, condená-la a pagar pela substituição da cidade do Rio de Janeiro como capital do país. O que se percebe é uma desconstrução de Brasília, até parecer ser orquestrada por inimigos da cidade; uma vez que procuram revelar fatos da podridão 
envolvendo personalidades dos três poderes, via manchetes jornalísticas envolvendo o nome de Brasília, como se a mesma tivesse poder para tomar decisões. Mas outro fato também a persegue, ignorar as várias e incontáveis qualidades da cidade.

A imprensa (do Rio e São Paulo) em matéria de divulgar o lado podre envolvendo o nome de Brasília se contrasta com a falta de estímulo em noticiar fatos positivos, e até mesmo elogiar decisões aqui tomadas e hoje repercutindo mundo a fora, se não vejamos alguns, como: proibir o fumo em locais fechados; prioridade de pedestre ao passar pela faixa própria em relação aos veículos; educação no transito - não se buzina nesta cidade - se respeita a preferência - se respeita a vagas de idosos e deficientes.

A população indignada pelas ações tomadas pelos parlamentares, os citam como "os políticos de Brasília", mesma sabendo que 99\% não são da capital, não moram, vivem ou mesmo votam aqui, e o mais surpreendente é que eles mesmos (os críticos de Brasília) os enviaram como seus representantes. Os brasileiros, até mesmo aqueles que não conhecem Brasília - e são mais de 150 milhões - possuem uma imagem pré-concebida, rotulada sobre a capital.

Ficou demonstrado que a realização de eventos combinada com a promoção do turismo interno torna eficaz o DESTINO Brasília, como foco irradiador de todas as culturas brasileiras. Um local a partir de onde todas as regiões / estados possam exibir sua cultura para o mundo, ganhando notoriedade e reconhecimento pelo alto valor agregado; item gerador de grandes negócios. Exibir a diversidade, pluralidade e valores agregados de maneira peculiar em cada uma das criações e vivências culturais do País, em Brasília, torná-la-á a Capital (também) Cultural no sentir (perceber) dos brasileiros.

A auto-estima do brasileiro se elevará ao promover o entusiasmo por criar, agregar valor e exibir a cultura brasileira. Promover Brasília, mais que capital, Capital Cultural de cada cidade, de cada estado, de cada país, de cada continente, também é valorizar o "ser brasileiro", enquanto elemento nascido de uma cultura de paz, que festeja o seu viver e que promove grandes festas para exibir sua maneira tão peculiar e interessante de produzir cultura.

Ao acompanhar a realização do 'Il Encontro do Nordeste' constatamos uma forte presença de público descendentes ou mesmo nordestinos, porem, também foi verifi- 
cado um razoável número de pessoas de outros estados com interesse em conhecer a cultura nordestina, por meio das atrações propostas, do artesanato exposto, da culinária típica oferecida, dentre muitos outros interesses.

Constata-se também o orgulho de ser nordestino ao depararem com sua cultura tão difundida no Brasil. Pelas entrevistas se verificou a satisfação resultante ao poderem 'matar as saudades' da sua região.

Ao analisar as ações propostas no 'Projeto Brasília Capital Cultural' referente ao 'Calendário Turístico Cultural de 2010 em Brasília', observa-se o grande conteúdo técnico e de excelente potencial para reposicionar a marca 'Brasília', bem como, angariar turistas para ocupar a rede hoteleira nos finais de semana da capital movimentando a capital.

As propostas do calendário são:

Na data de Janeiro - A realização do 'Reveillon Popular - Festa da Passagem de Ano' poderá ser aplicada para a captação de turistas e a melhor solução seria apresentações musicais de artistas de sucesso nacional e grande queima de fogos; montagem de camarotes especiais com ingresso grátis para quem se hospedar da rede hoteleira do Distrito Federal neste período. Participação de todos os estados brasileiros por meio de estandes especiais perfilados na Esplanada dos Ministérios, resgatando o evento 'Festa dos Estados' com entrada gratuita de toda a população, combinado com a participação dos Países de um 'Continente convidado' a cada ano; evento iniciado na semana de comemoração do natal. Divulgação nas principais cidades do Brasil.

Na data de Fevereiro - A realização do evento 'Alegria Alternativa' no período de carnaval poderá ser aplicada para a captação de turistas e a melhor solução seria realizar uma grande campanha nacional mostrando que em Brasília a alegria do carnaval é de forma alternativa com as realizações dos seguintes eventos: 'Mestres e Divas da MPB' apresentação de três duplas de artistas de sucesso nacional, homem e mulher, uma a cada dia, para ser realizado nos dias de domingo, segunda e terça-feira de fevereiro, no Pavilhão Expo Brasília, com decoração especial e ingresso grátis. Nos camarotes Vips (com cadeiras confortáveis e atendimento de bar exclusivo) será grátis para quem se hospedar, no final de semana deste período, na rede hoteleira do Distrito Federal; 'II Festival da Fé Cristã' apresentações de ban- 
das locais, nacionais e internacionais no estilo gospel a ser realizado no Pavilhão Expo Brasília, no sábado de fevereiro de 2010, uma virada de 12 horas de shows; 'Rebanhão' evento produzido pela Igreja Católica todos os anos na qual se deve apoiar para que tome dimensão nacional a ser realizado no ginásio Nilson Nelson de domingo a terça-feira de fevereiro de 2010; 'Celebração' evento produzido pela Igreja Evangélica todos os anos na qual se deve apoiar para que tome dimensão nacional a ser realizado no Centro de Convenções de Brasília de sábado a terça-feira de fevereiro de 2010; Divulgação nas principais cidades do Brasil;

Na data de Março - A realização dos finais de semana de março o 'Mês do Circo Especial da Família' - poderá ser aplicada para a captação de turistas e a melhor solução seria atrações inéditas com foco na família; Instalação do 'Circus Show' no estacionamento do estádio paralelo ao Centro de Convenções, com apresentações especiais e inéditas de circo em todo período do mês de março, com ingressos grátis nos camarotes Vips para quem se hospedar nos finais de semana, do mês de março, na rede hoteleira do DF; Realização dos eventos 'Family Show' no auditório máster do Centro de Convenções com apresentações inéditas dos espetáculos infanto-juvenis 'Lazy Town' na primeira semana de março, 'O Mágico de Oz' na segunda semana de março, 'Pinóquio' na terceira semana de março, e 'A Bela e a Fera' na quarta semana de março (os três últimos montagem da Broadway), com ingressos grátis nas poltronas vips para quem se hospedar nos finais de semana, do mês de março, na rede hoteleira do DF; Divulgação nas cidades próximas até 500 km de Brasília;

Na data de Abril - A realização de todos os finais de semana, e o mês de aniversário de Brasília, e especialmente, o final de semana que antecede o dia de aniversario, poderá ser aplicada para a captação de turistas e a melhor solução seria a instalação do complexo cenográfico 'Mundo Jurássico' a maior exposição de réplicas de dinossauros com movimentos mecânicos do planeta, no Centro de Convenções Área Sul, com ingressos grátis para quem se hospedar nos finais de semana, do mês de abril, na rede hoteleira do DF; nova apresentação do projeto 'Mestres e Divas da MPB' nos dias que antecede a data de aniversário, dia 21/Abr, com apresentações de três duplas de artistas de sucesso nacional, homem e mulher, uma a cada dia, a ser realizado no Centro de Convenções de Brasília, com ingresso grátis para quem se hospedar neste final de semana na rede hoteleira do DF; Divulgação nas 
cidades próximas até 500 km de Brasília para o projeto 'Mundo Jurássico' e nas principais cidades do Brasil para promoção governamental do Aniversario de 50 anos de Brasília.

Na data de Maio - Realização do 'Encontro do Nordeste' - poderá ser aplicada para a captação de turistas e a melhor solução seria o Lançamento e Prévia das Festas de São João do Nordeste - com a participação dos nove estados, montado no estacionamento e no ginásio Nilson Nelson, na segunda semana de Maio, com apresentações de música, dança, folclore, cultura popular, gastronomia, artesanato, produtos do nordeste, entrega de medalha ao 'filho ilustre' de cada estado pelos governadores de Brasília e dos estados agraciados, um a cada dia; Divulgação nas capitais e principais cidades de cada estado da Região Nordeste.

Verificar se na data de Junho - Realização do 'Encontro do Norte' - poderá ser aplicada para a captação de turistas e a melhor solução seria o Lançamento e Prévia dos Festivais Folclóricos do Norte - com a participação dos sete estados, montado no estacionamento e no ginásio Nilson Nelson, na segunda semana de Junho, com apresentações de música, dança, folclore, cultura popular, gastronomia, artesanato, produtos do norte, entrega de medalha ao 'filho ilustre' de cada estado pelos governadores de Brasília e dos estados agraciados, dois a três a cada dia; Divulgação nas capitais e principais cidades de cada estado da Região Norte.

Na data de Julho - Realização do 'Encontro do Sudeste' - poderá ser aplicada para a captação de turistas e a melhor solução seria o Lançamento e Prévia das Maiores Festas de Peão do Brasil - com a participação dos quatro estados do sudeste, montado no estacionamento e no ginásio Nilson Nelson, na segunda semana de julho, com apresentações de música, dança, folclore, cultura popular, gastronomia, artesanato, produtos nordestinos, rodeio de touros, torneio feminino de três tambores, entrega de medalha ao 'filho ilustre' de cada estado pelos governadores de Brasília e dos estados agraciados, um a cada dia; Divulgação nas capitais e principais cidades de cada estado da Região Sudeste.

Na data de Agosto - Realização do 'Encontro do Centro-Oeste' - poderá ser aplicada para a captação de turistas e a melhor solução seria o Lançamento e Prévia do Maior Festival de Pesca Esportiva do Mundo - com a participação dos quatro estados do Centro-Oeste, montado no estacionamento e no ginásio Nilson Nelson, na segunda semana de agosto, com apresentações de música, dança, folclore, cultura 
popular, gastronomia, artesanato, produtos do centro-oeste, entrega de medalha ao 'filho ilustre' de cada estado pelos governadores de Brasília e dos estados agraciados, um a cada dia; Divulgação nas capitais e principais cidades de cada estado da Região Centro-Oeste.

Na data de Setembro - Realização do 'Encontro do Sul' - poderá ser aplicada para a captação de turistas e a melhor solução seria o Lançamento e Prévia das Maiores Festas de Outubro do Sul - com a participação dos três estados, montado no estacionamento e no ginásio Nilson Nelson, na segunda semana de setembro, com apresentações de música, dança, folclore, cultura popular, gastronomia, artesanato, produtos do sul, entrega de medalha ao 'filho ilustre' de cada estado pelos governadores de Brasília e dos estados agraciados, um a cada dia; Divulgação nas capitais e principais cidades de cada estado da Região Sul.

Na data de Outubro - Realização do 'Encontro das Américas' - poderá ser aplicada para a captação de turistas e a solução mais adequada seria com a participação dos treze países da América do Sul, montado na Esplanada dos Ministérios, na segunda e terceira semana de outubro, com apresentações de música, dança, folclore, cultura popular, gastronomia, artesanato; Divulgação nas capitais Brasileiras e dos países participantes.

Na data de Novembro - Realização do 'Torneio Nacional de Balonismo', poderá ser aplicada para a captação de turistas e a área melhor seria na Esplanada dos Ministérios, na segunda semana de novembro, com a participação de 50 balões especiais multicoloridos percorrendo o Distrito Federal com pontuações válidas para o campeonato nacional; Divulgação nas cidades próximas até a 500 km de Brasília.

Na data de Dezembro - Realização do 'Espaço Natalino' poderá ser aplicada para a captação de turistas e a área melhor seria a Esplanada dos Ministérios com estandes cenográficos especialmente produzidos para as comemorações de natal, com apresentações musicais de corais de sucesso nacional, com montagem de camarotes especiais com ingresso grátis para quem se hospedar da rede hoteleira do Distrito Federal neste período; Participação de todos os estados brasileiros por meio de estandes especiais perfilados na Esplanada dos Ministérios, resgatando o evento Festa dos Estados com entrada gratuita de toda a população, combinado com a participação dos Países de um continente convidado a cada ano; evento estendido até o Reveillon Popular. Divulgação nas cidades próximas até 1.000 km de Brasília. 
Ao analisar a disposição dos gerentes de hotéis em participar de uma tabela de preço especial para o 'Projeto Brasília Capital Cultural', foi sugerido a seguinte classificação: aos hotéis de 3 estrelas a conversão de seus preços para $R \$ 40,00$ a diária de final de semana por pessoa; de 4 a $R \$ 50,00$ e 5 a $R \$ 60,00$, sendo disponibilizados somente duplos e triplos para pacotes de três dias como regra; a cada dia que diminuí do pacote foi proposto o acréscimo de $\mathrm{R} \$ 30,00$ por cada pessoa para hotel de 3 estrelas, $R \$ 40,00$ para os de 4 estrelas e $R \$ 50,00$ para os de 5 estrelas. Como serão disponibilizados somente duplos e triplos, conclui-se que cada apartamento terá a receita mínima de $R \$ 80,00$ para os de 3 estrelas, $R \$ 100,00$ para os de 4 estrelas, e 120,00 para os de 5 estrelas, para pacotes de três dias, totalizando respectivamente os valores de $R \$ 240,00, R \$ 300,00$ e $R \$ 360,00$. O preço sugerido é uma estratégia de marketing onde a população teria mais facilidade de guardar o valor proposto pelo número de estrelas correspondente de cada hotel.

Constata-se que esta oferta promocional pode cobrir parte dos custos fixos e parte dos custos variáveis para este segundo período. Em função disso o estabelecimento que vier praticar os preços sugeridos aumente a quantidade de locação dos apartamentos, colocando o ponto no gráfico da curva de oferta bem acima do 'ponto de fechamento' conforme ilustração abaixo, no ponto ' $A$ '. Para os hotéis novos, pesquisaremos se este mesmo preço esteja acima do 'ponto de break even ', no ponto ' $\mathrm{D}$ ', devido suposição de que a política de preço distribui o total dos custos fixos para a primeira tabela de preço (de segunda a sexta-feira), ou seja, não há custo fixo para ser mensurado no segundo período - finais de semana. Veja no gráfico abaixo. 
Gráfico 1 - Teoria da Firma.

Fonte: STIGLITZ (2000; 224).

Verificar-se que esta prática poderá proporcionar maior renda aos hoteleiros; eleva a oferta de trabalho na cidade (empregos diretos e indiretos); aumenta a arrecadação de impostos; proporciona novas atividades turísticas culturais; busca melhor relacionamento com as cidades brasileiras, seus estados e respectivamente suas regiões; consolida assim, a força da proposta do 'Projeto Brasília Capital Cultural'.

Ao perguntar aos gerentes das duas maiores companhias aéreas (TAM e GOL) se teriam interesse em investirem nas ações 'Calendário Turístico Cultural de 2010 em Brasília', responderam que sim, porem, para vir efetivar este compromisso, será necessário a participação de todo o trade. Ao sugerir preço de $\mathrm{R} \$ 50,00$ para passagem aérea para a vinda à Brasília e 50\% de desconto para volta ao estado/cidade de origem, sempre no período de hospedagem de 3 dias em Brasília, sendo acrescido mais $\mathrm{R} \$ 50,00$ por cada dia fora do pacote, entenderam ser possível, porem, mais uma vez será necessário a participação da rede hoteleira praticando preços promocionais para o mesmo período.

$\mathrm{Na}$ entrevista com a dirigente do Convention \& Visitors Bureaux foi constatado o grande interesse desta promoção, inclusive já está em andamento proposta a TAM 
da prática de preço em conjunto com os hotéis e empresas de receptivo pela entidade.

A ABIH tem a mesma intenção de promover o final de semana, embora não haja consenso. Alguns hoteleiros preferem agir conforme a ocasião e oportunidade, outros compreendem da necessidade de promoverem preços especiais, porem não tabelados.

Os agentes de viagem são favoráveis a qualquer promoção que venham fazer os hotéis e as companhias aéreas, uma vez que são comissionados pela venda do pacote e/ou prestação de serviço de receptivo e passeios turísticos culturais em Brasília e entorno.

Nos contatos executados por este autor aos parlamentares do outros estados ficou constatado o interesse dos mesmos, porem se acionados pelo governo dos seus estados. Normalmente estes parlamentares aplicam recursos de suas emendas individuais nos seus próprios estados, preferencialmente no reduto que os elegeram.

Ao perguntar do interesse em promover eventos culturais nas cidades de seu reduto eleitoral, e se participariam em convidar sua população para vir a Brasília a preço promocional, os mesmos informam que já fazem, alguns aplicando recurso em infraestrutura, outros em eventos. Para que eles venham a convidar a população nos seus eventos para vir a Brasília, nota-se que mantêm relação de afinidade com o prefeito eleito e que esta decisão ficaria para o mesmo.

Quanto à proposta de divulgar Brasília nos outros estados é consenso no órgão do Distrito Federal responsável, que é a Brasiliatur. Não foi possível constatar qualquer ação neste sentido por parte do órgão. Ao apresentar o equipamento em formato de avião ao diretor de marketing da Brasiliatur, o mesmo colocou sua impressão de aceitação, inclusive sugerindo que se propusesse a instalação do equipamento na cidade até o aniversário de 50 anos de Brasília, bem como sua inscrição para análise das personalidades convidada pelo governador para escolha dos projetos que farão parte dos festejos dos 50 anos de Brasília.

Da mesma forma o intercâmbio entre Brasília/DF e os outros estados são bem aceito. Ainda não há nenhuma ação para que esta ação possa ser efetivada. Acreditamos haver outras prioridades. 
Fica visível, portanto, que o deslocamento do viajante implica toda uma logística, a justificar a demanda pelos serviços técnicos de organização de todos os elementos necessários a uma jornada segura e agradável. 


\section{CONSIDERAÇÕES FINAIS}

Estabelecer nova percepção sobre a imagem de Brasília, uma vez que pode-se comprovar que seu nome é eventualmente conciliado a aspectos negativos oriundos da conduta irregular de parte dos políticos, é desafio necessário em vista do seu desenvolvimento social, turístico e econômico. Para isso é necessário que o seu nome, a partir do ponto de vista mercadológico, seja trabalhado como uma marca vendável.

Como apontam as principais estratégias de posicionamento, o "produto" Brasília deve ser conciliado a valores positivos, suas qualidades destacadas e que sejam criadas vantagens competitivas. Uma vez que sofre com a difamação de alguns setores da imprensa, é necessário reposicionar-se de forma a sobressair a esse fator.

É contundente afirmar que a melhor forma de atingir esses objetivos é tornar Brasília algo mais próximo do povo brasileiro. Que enxerguem na capital algo que se identifiquem e percebam semelhanças positivas. Pois, dessa forma, é possível criar uma possibilidade de aproximação, fundamental para a consolidação de uma imagem positiva.

A promoção dos 'Encontros Regionais', parte do 'Projeto Brasília Capital Cultural', reproduzem a diversidade turístico cultural e de comportamento de cada canto do país, é, portando, uma alternativa real, viável e de efeitos inegáveis. Uma vez que os brasileiros vejam sua capital como um espelho refletor de sua cultura, passarão a não olhá-la como uma cidade vinculada a corrupção e a escândalos políticos, mas sim, como uma parte importante na sua história, no seu desenvolvimento e na prospecção de seu futuro.

Alcançado esse objetivo, as possibilidades de desenvolvimento trazidas pelo turismo são imensuráveis. Com o amplo potencial que Brasília tem, pelos diversos fatores já citados nesse trabalho, o turismo fomentado pela promoção de eventos será uma janela para seus aspectos culturais mais importantes, exatamente como enquadra KOTLER e REIN, "O turismo baseado em eventos tornou-se um componente fundamental dos programas de atração turística. Os lugares pequenos ou rurais geralmente começam com um festival ou outro tipo de evento para definir sua identidade". 
Contudo, não restam dúvidas de que os eventos são um grande meio de geração de empregos e desenvolvimento não apenas da infra-estrutura turística, mas do turismo como um todo, pois é um setor que impulsiona a cadeia econômica e envolve dezenas de atividades, num círculo virtuoso que irriga a economia e fomenta o desenvolvimento de cada região.

Pode-se ter uma idéia da amplitude do universo dos eventos quando se observa que, além dos congressos, seminários, palestras, feiras e simpósios, também existem e envolvem milhões de pessoas, só no Brasil, o fenômeno das festas populares, os rodeios e os eventos culturais e esportivos.

Esse segmento movimenta milhões de reais todos os dias, consolidam contatos comerciais e lançamento de novos produtos, aumentam a taxa de ocupação e, conseqüentemente, as receitas das empresas de transporte e acomodações nos períodos de recesso ou baixa temporada e incrementa a arrecadação de impostos e tributos em virtude do desenvolvimento das vendas e da atividade econômica em geral. Utiliza-se de diferentes profissionais, com diversos níveis de capacitação, e, por isso, o setor contribui de forma sem igual para o desenvolvimento social e melhoria de vida para a população como um todo. Uma vez que a responsabilidade de destacar os pontos positivos das localidades e desenvolver uma estrutura que potencialize seus atrativos, beneficia não só os turistas, como os habitantes do local.

Exatamente como afirma Hoeller "O turismo de eventos é a parte do turismo que leva em consideração o critério relacionado ao objetivo da atividade turística. É praticado com interesse profissional e cultural por meio de congressos, convenções, simpósio, feiras, encontros culturais, reuniões internacionais, entre outros, e é uma das atividades econômicas que mais crescem no mundo atual". Portando, o impacto econômico e comercial gerado pelo turismo de eventos, é inegavelmente fator a ser levado em consideração. Sendo responsável por grande parte dos fluxos turísticos para alguns destinos brasileiros, possibilita que Brasília, uma cidade dotada de bens e pontos turísticos fique ainda mais atrativa e destacada em relação ao cenário nacional. O potencial da cidade para essa prática é notável quando se compara as cidades mais próximas como Goiânia e Uberlândia, em relação à importância de sua localização o alto índice de desenvolvimento e qualidade de vida.

A força desse tipo de iniciativa pode ser verificada em ocasião do II Encontro do Nordeste. Os resultados da pesquisa aplicada durante o evento bem como o suces- 
so de captação de visitantes de outros estados e regiões, pode comprovar de maneira sólida e eficácia de ações como essa para o aquecimento do turismo no DF. Ainda nesse sentindo, a temática regional foi amplamente aceita pelos entrevistados. Segundo VAZ (1999), nesse caso, a motivação que leva uma pessoa a viajar merece uma abordagem precisa. O elemento que está na origem do impulso de viajar é a fonte motivadora, e podem estar ligada a diversos fatores pessoais, familiares e sociais. Nesse sentido, os estados distantes do Nordeste e próximos a Brasília, com habitantes migrantes a região ou seus descentes, são os que mais fornecem turistas que buscam encontrar sua cultura. Goiás, Minas Gerais e São Paulo são os três estados, segundo apontou a pesquisa, que mais representaram o restante do país no Encontro do Nordeste. Verifica-se então a validade dessa proposta. Uma vez que mobiliza, devido ao seu diferencial, gente de várias partes do país.

Com base nos levantamentos propostos, pôde-se evidenciar a opinião dos diretores e gerentes de empresas áreas e redes de hotel acerca da importância de tais eventos, e à postura que poderia ser adotada em nível mercadológico para o incentivo e a continuação dessa iniciativa. Percebendo que há ainda um equilíbrio de opinião no que condiz a aceitação de reduções tarifárias nos fins de semana em que ocorressem os encontros. Ainda nessa vertente, constatou-se que os efeitos da sazonalidade, que prejudicam todo o trade, podem ser reduzidos, acreditam, porém, ainda não há um alto nível de confiabilidade.

Embasado em Albuquerque, "O turismo de eventos é também conhecido como o turismo de baixa estação por ser responsável por manter em movimento as atividades no setor durante os meses em que o turismo de lazer é mais fraco, gerando grandes valores, uma vez que os turistas de eventos geralmente dispõem de mais recursos financeiros nas viagens", pode-se dizer que tão desconfiança é oriunda de uma cultura ainda pouco empreendedora do trade local, acostumado a uma utilização padrão sobre a rotina da cidade.

Conclui-se a partir dá análise de todo o conteúdo que compõe esse projeto, pode-se provar a necessidade existente no desenvolvimento de um trabalho de reposição de imagem da cidade, tendo como principais ferramentas a promoção dos "Encontros Regionais" e o 'Avião - Espaço da Capital' que, ao mesmo tempo, promove o Brasil e Brasília nos maiores eventos em todos os estados e homenageia Santos Dummont, um dos maiores heróis brasileiros, tudo isso fazendo alusão a forma geográfi- 
ca da capital do país, alem de transmitir a idéia de um novo símbolo atual e moderno do turismo. Esses três fortes instrumentos de comunicação atendem de maneira eficiente aos componentes de um planejamento de marketing elaborado em detrimento da venda de um produto.

Ainda nesse sentido, dará a Brasília os atrativos culturais e comerciais que, como foi visto no que trata o turismo, causam impactos diretos e imediatos na economia e na imagem da destinação. A proposta desta tese tornasse, dessa forma, solidamente embasada em uma série de itens analisados que envolvem completamente o universo mercadológico relacionado aos principais temas: Imagem, eventos e turismo. Mesmo porque, comprova a relação direta entre eles e a maneira como podem ser manipulados em favor das necessidades da capital. 


\section{REFERÊNCIAS}

AAKER, David A. Marcas Brand Equity: Gerenciando o Valor da Marca. São Paulo: Negócio Editora, 1998.

ALLEN, J. et al. Organização e gestão de eventos. São Paulo: Campus, 2003.

ACERENZA, Miguel Angel. Administração do turismo: conceituação e organização. Tradução: Graciela Rabuske Hendeges - Bauru, SP: EDUSC, 2002.

ANDRADE, R. B. Manual de Eventos. Caxias do Sul: Educs, 1999.

BARRETO, M. Manual de Iniciação ao Estudo do Turismo. 3. ed. Campinas: Papirus, 1998.

BENI, Mario Carlos. Análise Estrutural do Turismo. São Paulo. SENAC, 1998.

BENI, Mario Carlos. Globalização do Turismo: megatendências do setor e a realidade brasileira. 2 ed. São Paulo. Aleph, 2004.

BRITO, J. e FONTES, N. Estratégia para Eventos: uma ótica do marketing e do turismo. São Paulo: Aleph, 2002.

CAMPOMAR, M. C. Do uso do estudo de caso em pesquisas para dissertações e teses em administração. Revista de Administração, São Paulo, v. 26, n. 3, p. 9597, julho/setembro 1991.

CANTON, A. M. Eventos: ferramenta de sustentação para as organizações do terceiro setor. São Paulo: Roca, 2002.

CESCA, C. G. G. Organização de Eventos. São Paulo: Summus, 1997.

CHURCHILL JR, Gilbert A. \& PETER, Paul. Marketing: Criando Valor para os Clientes. São Paulo: Saraiva, 2000.

COBRA, M. Marketing de Turismo. São Paulo: Cobra, 2001.

DENCKER, A. F. M. Métodos e Técnicas de Pesquisa em Turismo. 2. ed. São Paulo: Futura, 1998.

FARIA, A. L. L.; ZANINI, C. R. Eventos como estratégia de marketing para o turismo. Estudos Turísticos, São Paulo, 23 nov. 2003. Disponível em: <http://www.estudosturísticos.com.br>. Acesso em: 26 nov. 2003. 
FAZZINI, C.; PALLADINO, R. Turismo de eventos. Revista Turismo em Números. São Paulo, n.15, p. 8-16, out. 2003.

FIGUEIREDO, Marcus. A cidade na vitrine. Cidade, São Paulo, ano 03, n¹9, fev 1998.

FUNDAÇÃO GETÚLIO VARGAS. Caderno de Estatísticas da Revista Turismo em Números, São Paulo, 2004.

GIACAGLIA, M. C. Organização de Eventos: teoria e prática. São Paulo: Pioneira Thomson Learning, 2003.

GIÁCOMO, C. Tudo acaba em festa: evento, líder de opinião, público. São Paulo: Scritta, 1997.

GIL, A. C. Como elaborar projetos de pesquisa. 3a edição. São Paulo: Atlas, 1991. GODIN, Seth. Brinde! Grátis ! Aproveite!: a sua próxima grande idéia de marketing. Tradução de Ricardo Bastos Vieira.- Rio de Janeiro: Elsevier, 2004.

GOMES, N. Publicidade ou propaganda. É isso aí! Revista Famecos, Porto Alegre; $n^{\circ} 16$, dezembro 2001.

GRACIOSO, F. Contato Imediato com Marketing. São Paulo: Global, 1998.

HAZIN, A. L.; MEDEIROS, R.; OLIVEIRA, C. F. G. Turismo e mão de obra: entre o real e o ideal. Recife: Unicap, 2000.

HOELLER, E. H. Turismo de eventos: Centreventos Cau Hansen de Joinville - SC. In: Turismo e Segmentação de Mercado. São Paulo: Futura, 2002.

IGNARRA, Luiz Renato. Fundamentos do Turismo. São Paulo; Pioneira Thomson Learning, 2002.

KOTLER, Philip \& KELLER, Kevin. Administração de Marketing. 12a ed. São Paulo: Pearson Prentice Hall, 2005.

KOTLER, P. Administração de Marketing. 5. ed. São Paulo: Prentice-Hall, 1998.

KOTLER, P.; ARMSTRONG, G. Princípios de Marketing. Rio de Janeiro: PHB, 1993. MATIAS, M. Organização de Eventos. Barueri: Manole, 2002.

MELO NETO, F. P. Marketing de Eventos. Rio de Janeiro: Sprint, 1999.

RICHARDSON, R. J. Pesquisa social: métodos e técnicas. São Paulo. Atlas: 1985. 
RIES, Al; TROUT, Jack. Posicionamento - A batalha pela sua mente. 8.ed. São Paulo: Pioneira, 1999.

RUSCHMANN, D. Marketing turístico: um enfoque promocional. 4. ed. Campinas: Papirus, 1999.

SANT'ANNA, Armando. Propaganda - Teoria, Técnica, Prática. $7^{a}$ ed. São Paulo: Pioneira, 2000.

SILVA, N. C. O Grande Negócio do Turismo. Salvador Convention Online, Salvador, [2003]. Disponível em: <http://www.salvadorconvention.com.br> Acesso em 26 nov. 2003.

TRIGUEIRO, Carlos Meira. Marketing \& Turismo: como planejar e administrar o marketing turístico para uma localidade - 1 ed- Rio de Janeiro. Qualitymark, 2001.

VAZ, G. N. Marketing turístico: receptivo e emissivo. São Paulo: Pioneira, 1999.

ZANINI, C. R.; FARIA, A. L. Eventos: uma ferramenta de desenvolvimento turístico. Florianópolis: Empretur, 2003.

ALBUQUERQUE, S. S. Turismo de Eventos - A Importância dos Eventos para o Desenvolvimento do Turismo. Brasília, monografia. CET. 2004.

CARVALHO, E. M. A. Marketing "boca a boca" positivo aplicado em Serviço de Buffet. Brasília, monografia. CET. 2003.

Dimensionamento Econômico da Indústria de Eventos no Brasil, Sebrae e Revista dos Eventos. 2001/2002 in.

EMBRATUR, Relatório de Estudos de Demanda Turística. Brasília, 1998.

GIRALDI. J.M.E. e LIBONI L.B. Mapa Perceptual: Uma Ferramenta para Gerenciamento do Posicionamento de Marcas. Ribeirão Preto, Universidade de São Paulo. 2000.

NOGUEIRA, A.; SIMÕES, M. C. M. Turismo de eventos é visão e ação: uma proposta para Campo Grande - Campo Grande, monografia (graduação em Turismo). Universidade Católica Dom Bosco. 2001.

PELLEGRINI FILHO, A. Dicionário Enciclopédico de Ecologia \& Turismo. São Paulo: Manole, 2000. 
SILVA, J. M. da; SILVEIRA, E. S. Apresentação de trabalhos acadêmicos: normas e técnicas. Juiz de Fora, monografia. Juizforana, 2003.

TENAN. I. P. S. Eventos - Coleção ABC do turismo. São Paulo: Aleph, 2002.

TOMIKAVA, J. M. A Importância da Imagem no Processo de Escolha da Destinação Turística. Brasília, monografia. CET. 2004. 


\section{APÊNDICES}

\section{Apêndice A - Detalhamento da Ação Encontros Regionais.}

\section{FESTIVAIS TURÍSTICOS CULTURAIS DE CADA REGIÃO}

Por meio dos Encontros Regionais, será homenageada cada região brasileira por vez, realizando atividades interativas, com o objetivo de integrar cada uma das regiões a Brasília, vitrine do Brasil, promovendo, por meio de mostras de arte, cultura e recursos turísticos de cada região, uma confraternização maior entre o povo de Brasília e todas as outras culturas que formam a nossa!

A maior premissa é a de elevar a auto-estima do povo brasileiro, através das ações de integração que pode realizar nesses festivais, pois, em Brasília, todos terão a oportunidade de conhecer o Brasil, e os 'Brasis' que serão trazidos!

Brasília é mais que Capital, é Capital Cultural (da região homenageada).

As apresentações musicais, com os shows mais expressivos regionalmente, e com os artistas de maior destaque, de cada uma dos estados brasileiros será proposto por Brasília, ou seja, a cidade é quem reconhecerá e agraciará o artista escolhido.

Aqui, se efetivará apresentações de grandes artistas, onde cada governante poderá homenagear um filho ilustre, na abertura do evento de cada estado participante. Nosso objetivo e alcançar toda população da região homenageada pela realização dos Festivais e conquistar sua simpatia pela atitude de Brasília procurar fortalecer perante o Brasil, daquilo que mais gosta o povo daquela região.

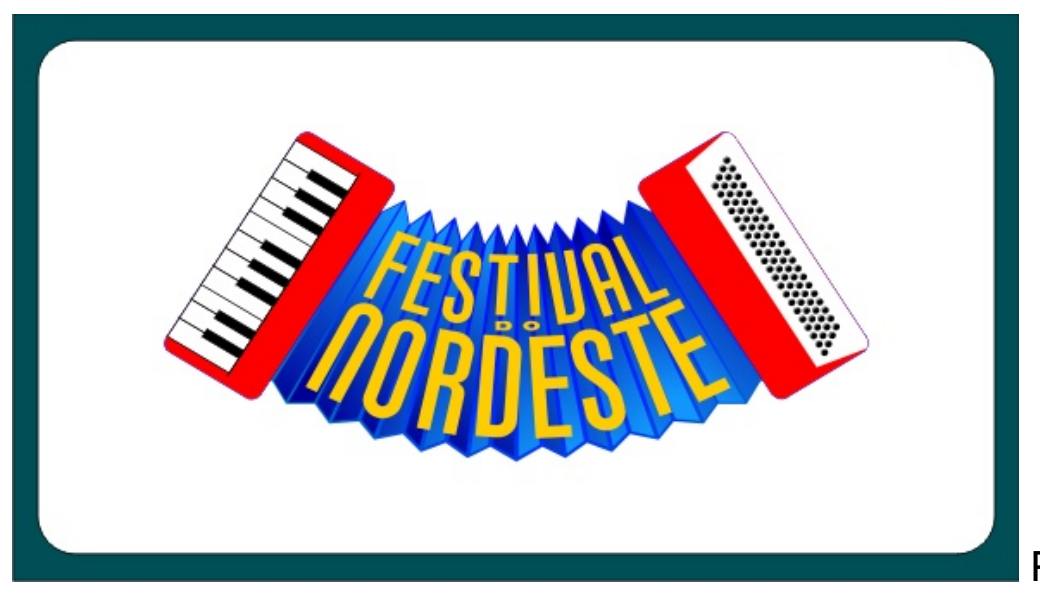




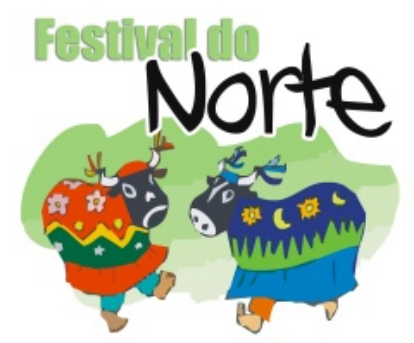

Gultura . Desenvolvimento . Turismo

Para ser realizado em Junho

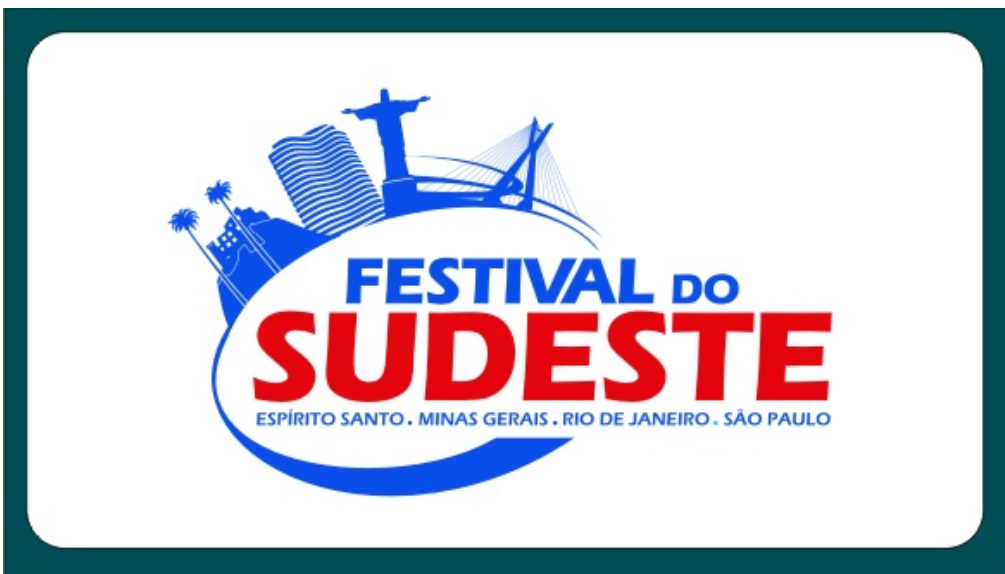

Para ser realizado em Julho

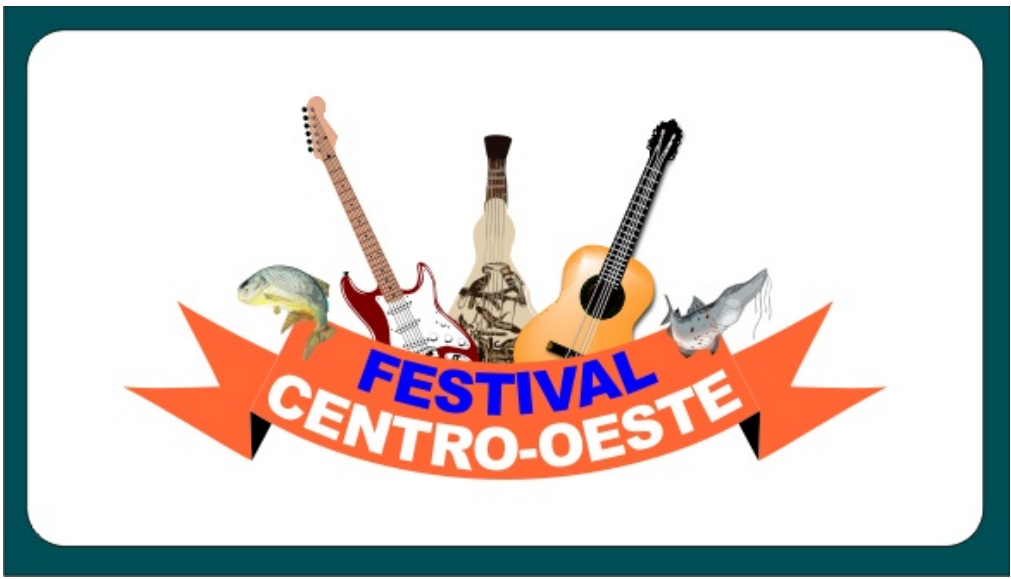

Para ser realizado em Agosto

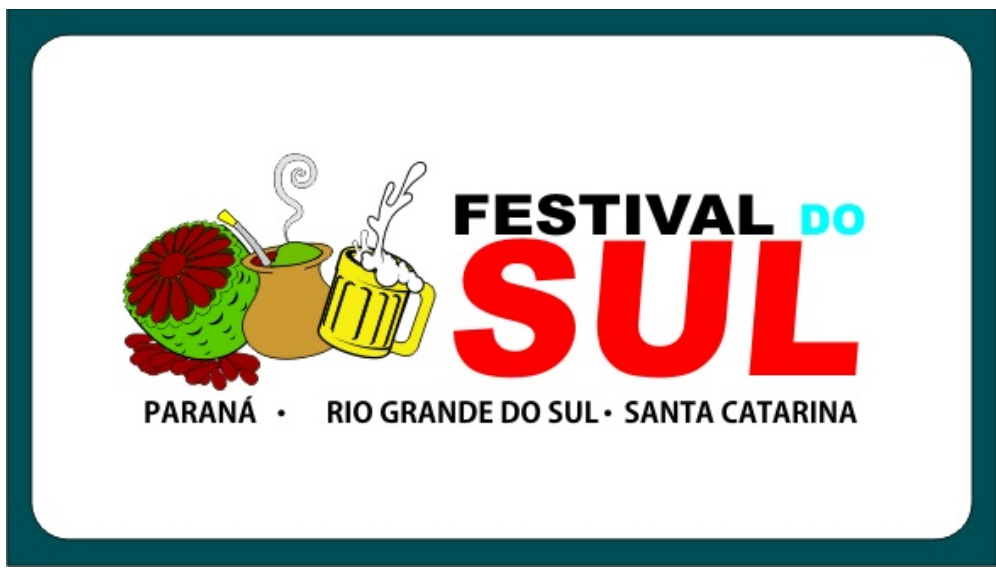

Para ser

realizado em

Setembro 
Esse projeto tem o sentido de agregar valor ao nome de Brasília com os outros estados do Brasil, onde a marca "Brasília" deve ser gerenciada de forma agressiva, bem como divulgar a capital nas capitais e principais cidades de cada estado.

É necessário que se agregue a idéia emocional de "capital cultural" da idéia cívica de "capital federal" transmitida continuadamente, que se torna um aspecto do reposicionamento do que se deve fazer, tirando o foco de uma capital administrativa para focar no povo receptivo e acolhedor que é o brasiliense.

Formular o Mix do Marketing com objetivo de atender às expectativas do mercadoalvo é fundamental, onde se procurará as características desejadas, com peço adequado, distribuindo em pontos de vendas específicos com uma comunicação segundo os desejos do consumidor local. Brasília será divulgada em cada local como capital cultural de cada região (veja ilustração), de cada estado, de cada cidade, onde se poder integrar em parceria.
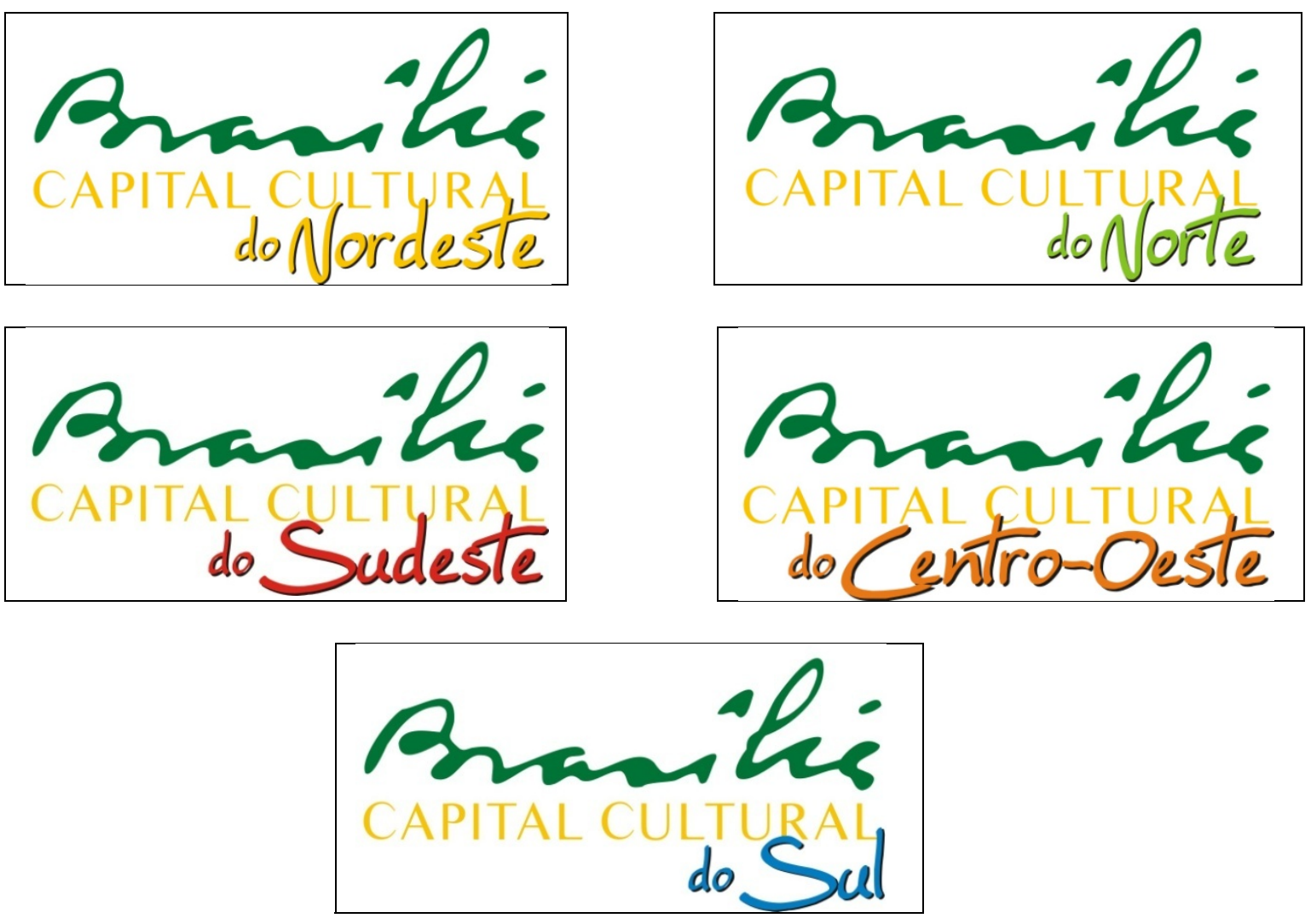

Em Brasília procurar-se-á reconquistar as classes sociais com estratégias direcionadas a cada uma delas, observando suas necessidades e desejos, para proporcionar a satisfação desejada de maneira mais efetiva e eficiente. Pessoas compram produtos e serviços, a fim de se divertir, criar fantasias e obter emoções e sentimentos. 
Para 'classe A' buscar-se-á ofertar oportunidades no evento de forma a promover reconhecimento e auto-realização, como a possibilidade de instalar restaurante conhecido de cada estado, montagem de estande de pelo menos dois grandes hotéis da região.
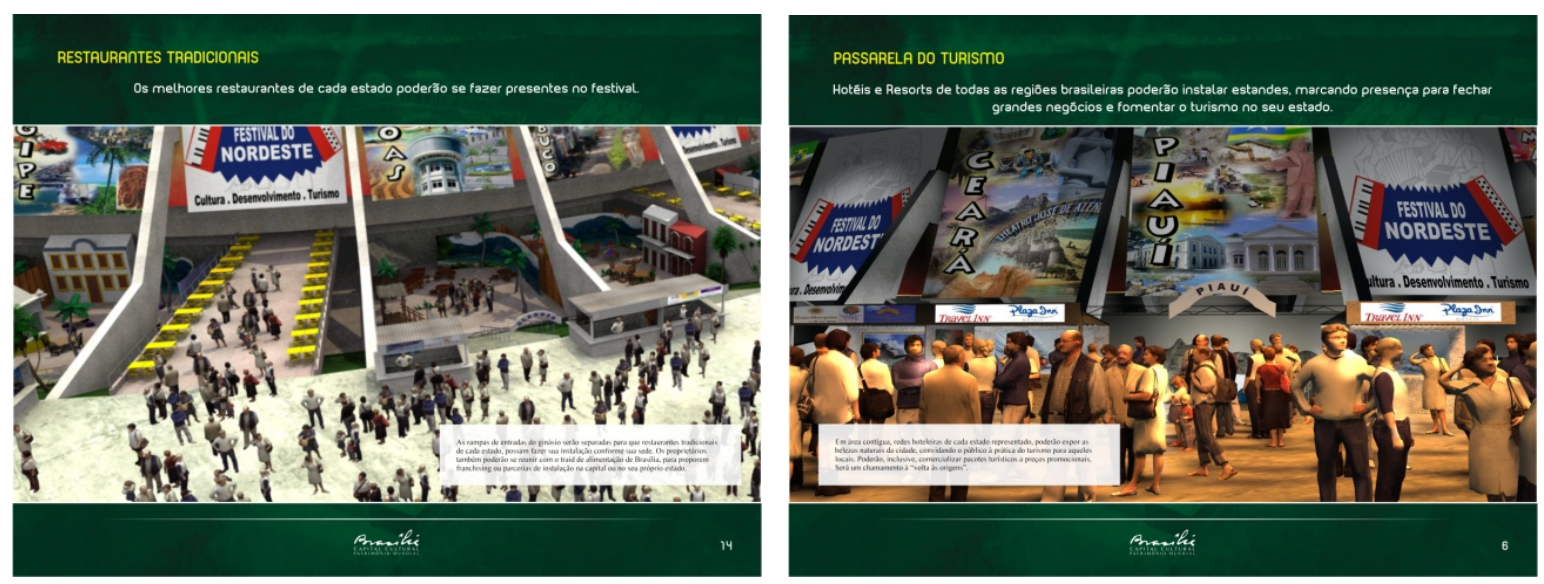

Para a 'classe B' buscar-se-á o relacionamento passando a sensação de pertencer, elevando a auto-estima ao associá-lo ao evento com alto envolvimento, oferecendoo o camarote do evento, participação na comitiva do governador ou prefeito para representação da cidade ou estado.

\section{RESTAURANTES TÍPICOS}

Uma área de alimentação totalmente adequada à região homenageada, onde poderá ser montado um restaurante conhecido de uma cidade do estado e, ao adentrar ao local escolhido, o público irá sentir-se em seu próprio estado ali representado, pois os mesmos serão totalmente ambientados com painéis e fotos; o atendimento será feito por garçonetes e garçons vestidos em trajes regionais; os pratos serão típicos, enfim: todo o ambiente propiciará ao público sentir-se viajando, virtualmente, ao estado. O nome deste restaurante será o mesmo da sua origem. Característica do padrão de organização - INTERDEPENDÊNCIA

\section{PASSARELA DO TURISMO}

Em área contígua, um local 'abrigará' dois hotéis ou resorts da região representada, onde essas empresas poderão expor as belezas naturais da região, convidando o público à prática do turismo para aqueles locais. Poderão, inclusive, comercializar pacotes turísticos a preços promocionais. Será um chamamento à "volta às origens". Característica do padrão de org. - FLEXIBILIDADE e INTERDEPENDENCIA. 

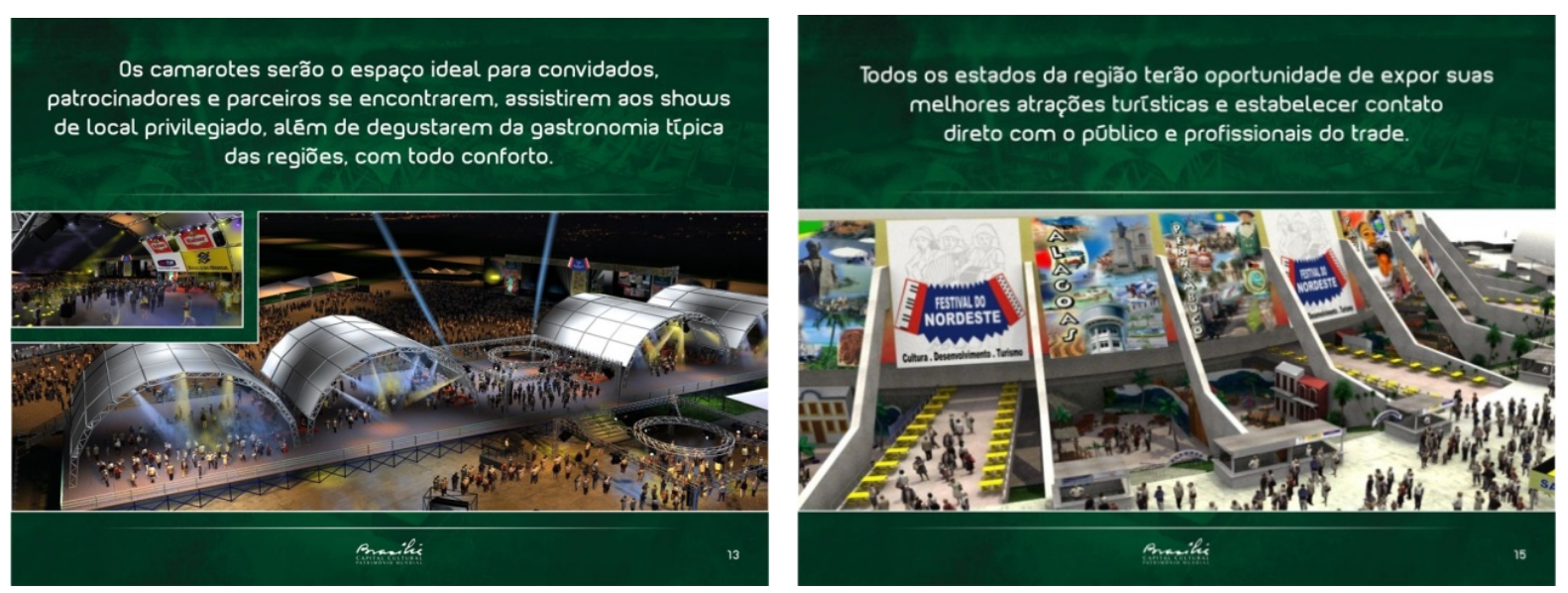

E para a 'classe C e D oportunizar-se-á meios para que venham ganhar dinheiro na capital por meio de exposições e venda de seus trabalhos, sejam eles gastronômicos, artesanais ou até mesmo, por meio de apresentações da cultura popular e folclore da sua região.

\section{CAMAROTES}

Serão dispostos camarotes Vips, com visualização privilegiada do palco principal e de toda área da Praça do Povo. O acesso a esses camarotes será para qualquer pessoa que esteja hospedado na rede hoteleira de Brasília no período do evento. Também os convidados dos governadores e prefeitos das cidades homenageadas, além de convidados dos patrocinadores e colaboradores. Característica do padrão de organização - PARCERIA e INTERDEPENDÊNCIA.

\section{PASSARELA DOS ESTADOS}

Espaço destinado a cada Estado, com a finalidade de cada um mostrar ao público toda sua diversidade cultural e turística, com instalações e montagens de cenários. Nas paredes externas do ginásio, poderão ser instalados grandes 'front lights', um de cada estado; com ilustrações de paisagens naturais e arquitetura predial. No local poderão ser expostos materiais de divulgação de cada Estado, e a recepção será feita por pessoas da localidade com vestimenta típica e sotaque próprio. Característica do padrão de organização - PARCERIA. 

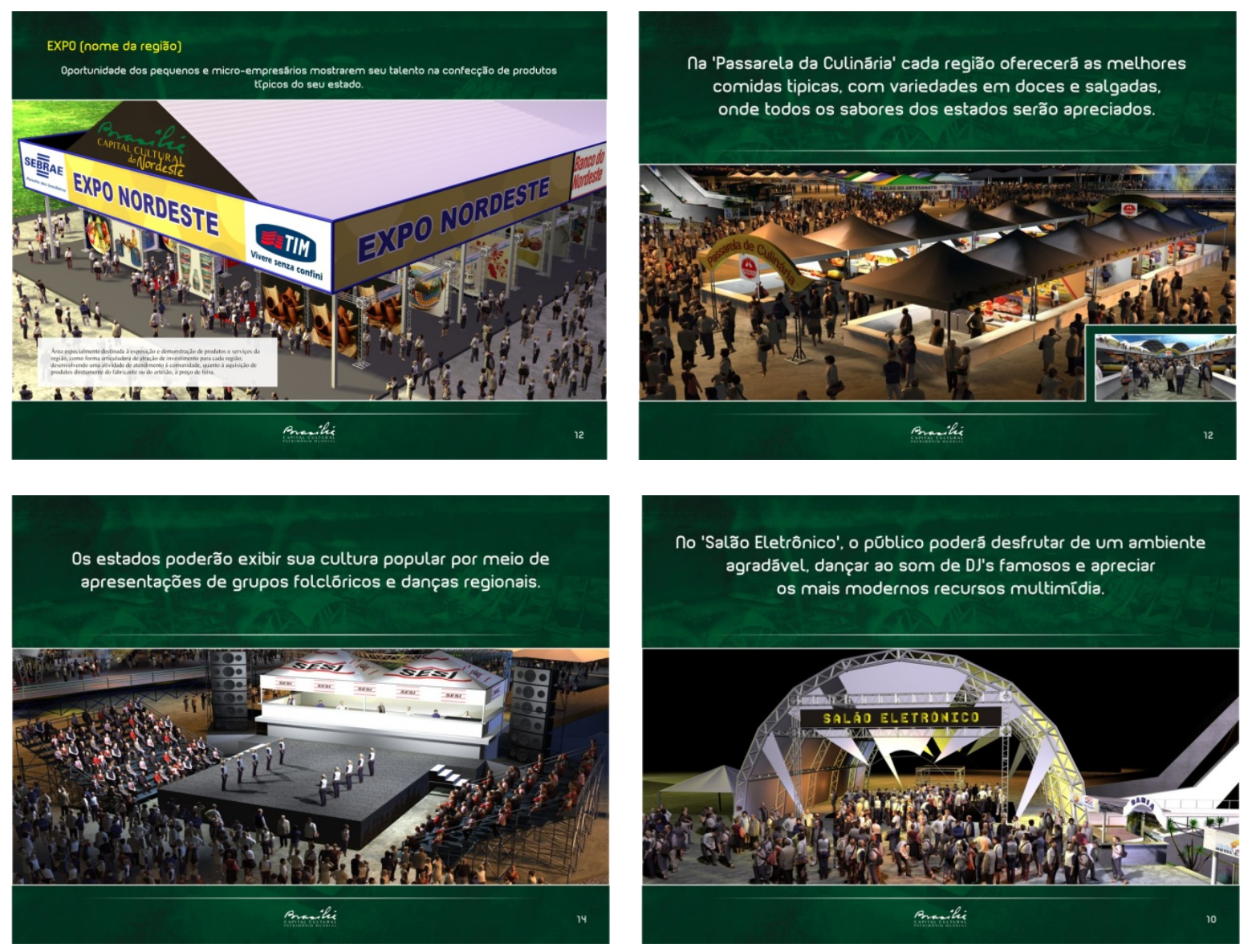

\section{EXPO}

Área especialmente destinada à exposição e demonstração de produtos culturais da região, como forma articuladora de atração de investimentos para cada região; desenvolvendo uma atividade de atendimento à comunidade, quanto à aquisição de produtos diretamente do fabricante ou do artesão, a preço de feira. São produtos ecologicamente corretos, onde são utilizados matérias da natureza produzidas pelos próprios artesões que também estarão vendendo seu produto diretamente ao público presente. Realizar-se-á o Comercio Justo - sem intermediário. Característica do padrão de organização - PARCERIA, RECICLAGEM e DIVERSIDADE.

\section{PASSARELA DA CULINÁRIA}

São dois conjuntos de estandes que estarão dispostos em duas passarelas, uma de doces e outra de salgados. Cada estande oferecerá ao público uma especialidade diferente, de acordo com as especificidades de culinária de cada região. Neste sistema de negocio serão convidados mestres da culinária típica de cada estado para empreender nesta área de trabalho, produzindo diretamente para o público presente. Realizar-se-á o Comercio Justo - sem intermediário. Característica - PARCERIA. 


\section{PALCOS ALTERNATIVOS}

Disponibilizar-se-á, em dois palcos alternativos, apresentações de danças e demais expressões folclóricas de cada localidade, em relação às quais o público poderá interagir livremente, criando oportunidades de muita diversão, em segurança. Grupos folclóricos regionais farão apresentações, convidando o público a participar. Montagem de arquibancadas envolta da arena. Característica do padrão de organização INTERDEPENDÊNCIA.

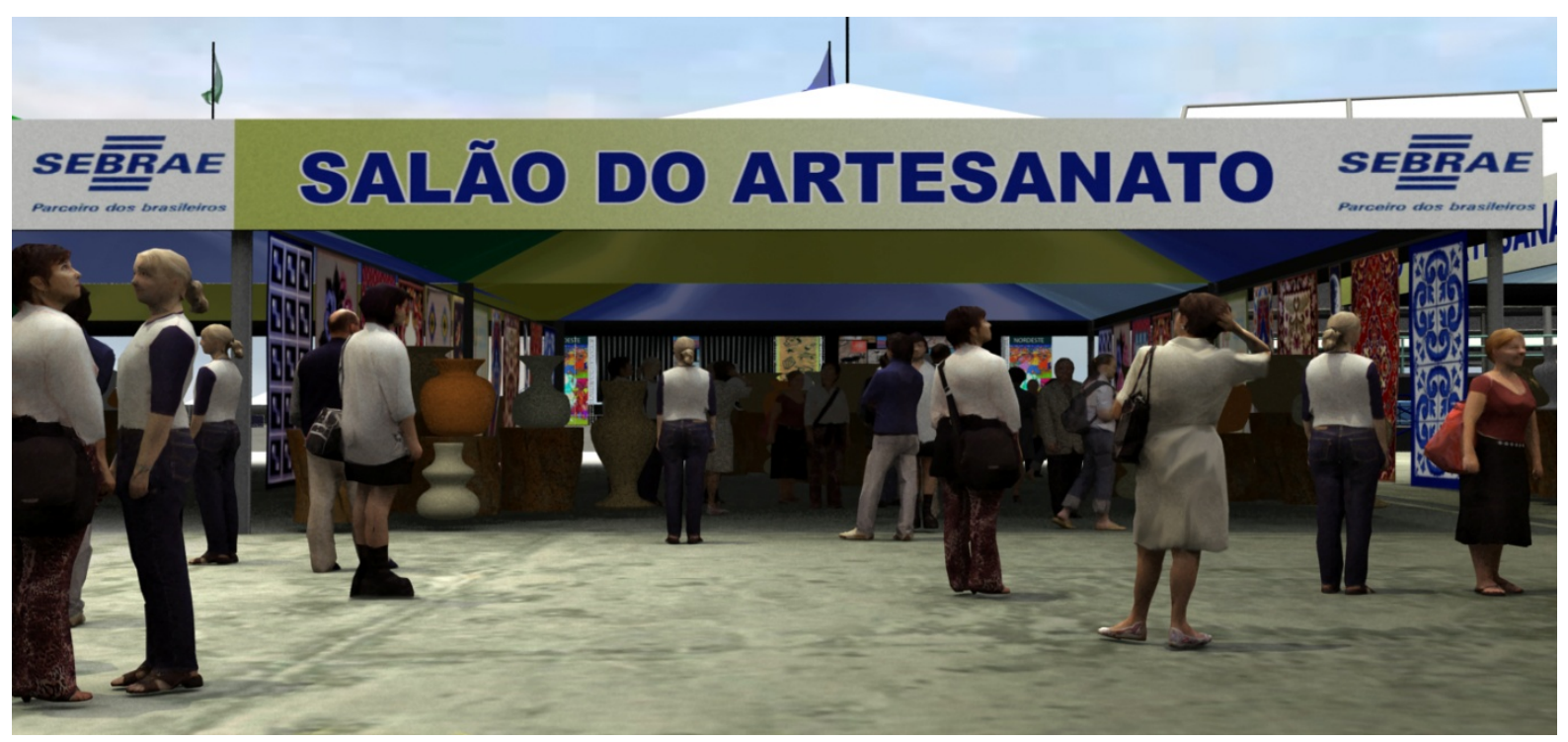

\section{SALÃO DO ARTESANATO}

Nessa área, o público poderá vislumbrar o artesanato típico de cada estado / região, podendo também adquirir produtos, que serão disponibilizados diretamente pelos produtores / fabricantes, a preços praticados no local de origem. Comercio Justo sem intermediário. Característica do padrão de organização - PARCERIA, RECICLAGEM e DIVERSIDADE.

\section{FILHO ILUSTRE}

Anualmente poderá ser identificado um artista que se destacou e que trouxe prestígio para seu estado, o qual será convidado a realizar shows antológicos, onde o artista homenageado poderá receber convidados especiais, como outros cantores de sucesso nacional, músicos que iniciaram carreira por seu intermédio, dentre outras homenagens pertinentes que poderão ser feitas. Característica do padrão de organização - PARCERIA. 


\section{no 'Palco Principal', artistas de renome nacional representarão suas regiōes.}

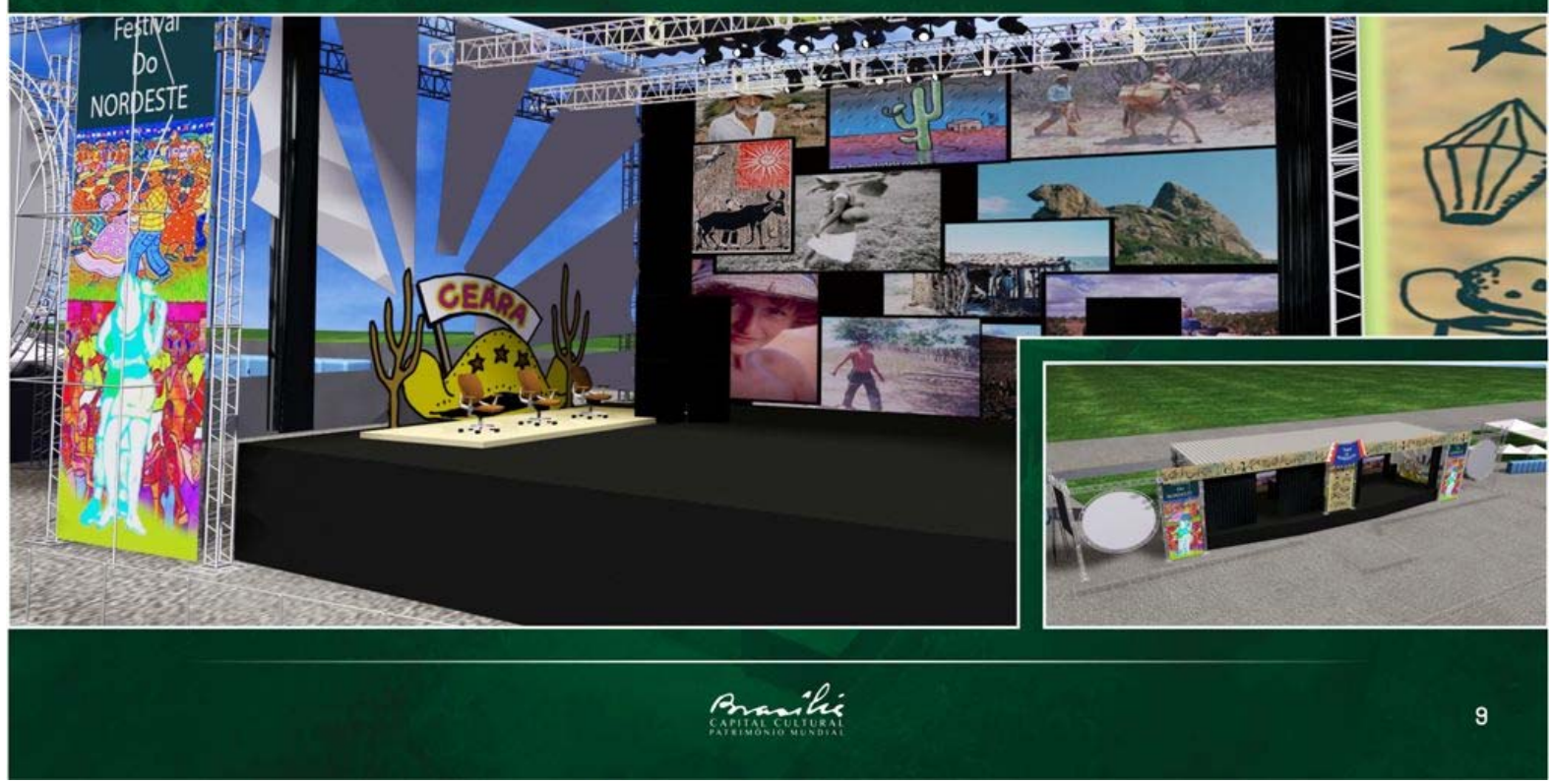

PODIUM DO GOVERNADOR - HOMENAGEM AO "FILHO ILUSTRE"

No palco principal, durante a apresentação do 'filho ilustre', representando um dos estados da região homenageada na ocasião, disponibilizar-se-á uma área especial, o PODIUM, para que o governador (ou representante) daquele estado aguarde o momento da entrega, publicamente, da medalha 'Carlos Gomes' a esse Filho Ilustre, na presença do povo e da imprensa convidada.

A Sociedade Brasileira de Arte, Cultura e Ensino - SBACE, por meio de seu Primeiro Chanceler, Valdemar Cunha, investido da função de dar reconhecimento e notoriedade a 'Filhos llustres', por meio da entrega da referida medalha, poderá oferecer ao governador (ou representante) de cada estado, a oportunidade de homenagear o 'Filho Ilustre' do seu estado, com a entrega da Medalha Carlos Gomes, conferindoIhe reconhecimento na área musical, enaltecendo e criando uma inter-relação com o fato de que foi Carlos Gomes o primeiro músico brasileiro a ser reconhecido, nacional e internacionalmente. Característica do padrão de organização - PARCERIA, DIVERSIDADE e INTERDEPENDÊNCIA. 


\section{Apêndice B - Embarcações no Lago Paranoá}

Brasília é a terceira maior cidade em concentração de embarcações de esporte e recreio do país, perdendo somente para São Paulo e Rio de Janeiro, tendo o Lago Paranoá espelho d'água de $40 \mathrm{Km}^{2}$

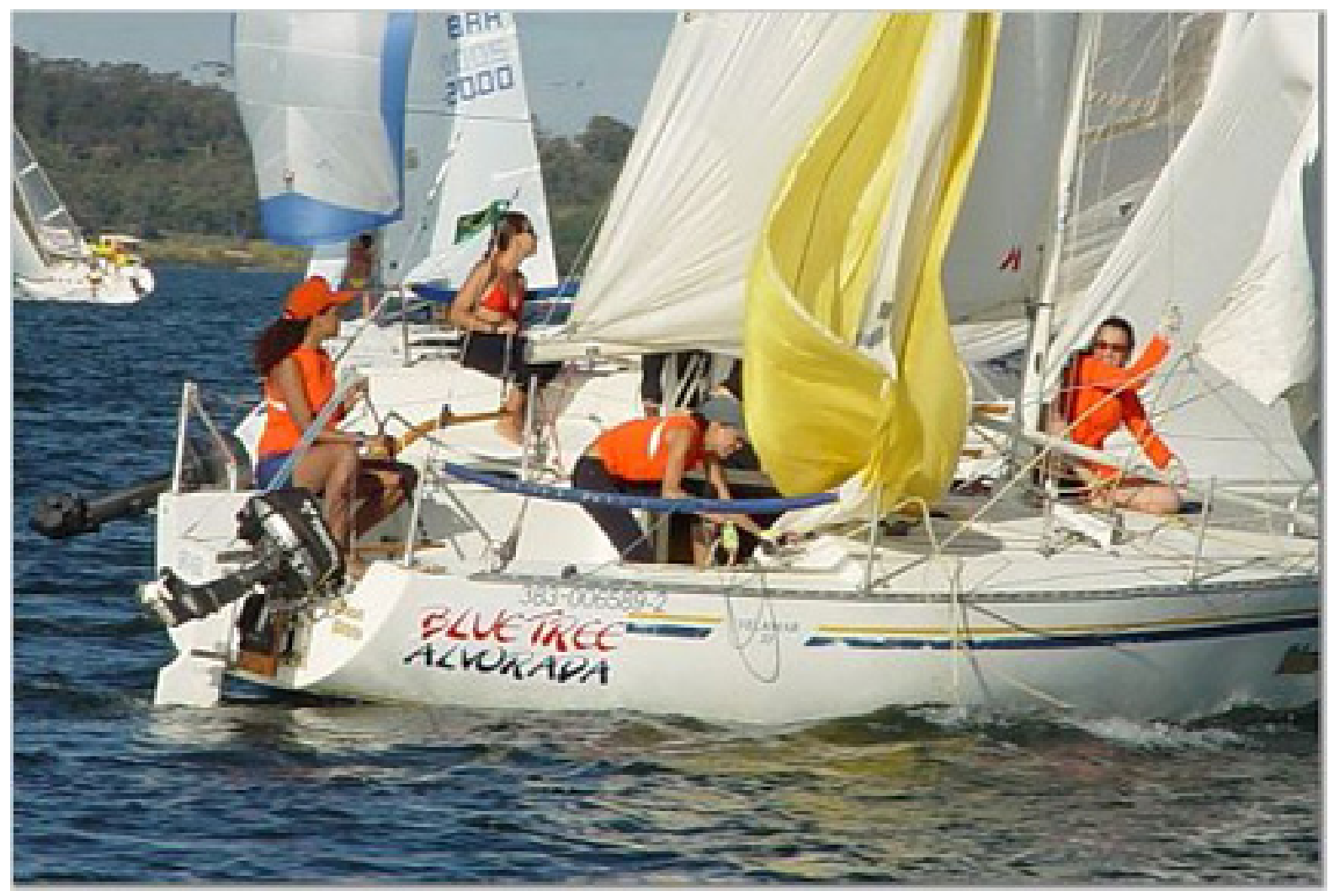

Muitas atrações náuticas são organizadas durante todo o ano com a participação de grande numero de participante, não só da cidade, mas atraindo turistas de esporte de toda parte do Brasil.

A cidade tem potencial ainda maior para agregar valor às atividades náuticas.

Para a realização do Encontro do Sudeste, por exemplo, se planeja realizar o peixamento (colocação de peixes) em parte do lago Paranoá, com o objetivo de se poder realizar uma grande torneio de pesca esportiva, nos moldes de Cárcere/MG. 


\section{Apêndice C - Detalhamento da Ação Espaço da Capital}

Espaço da Capital - Equipamento que mostrar a grandeza de Brasília e a diversidade cultural de todos os estados brasileiros.

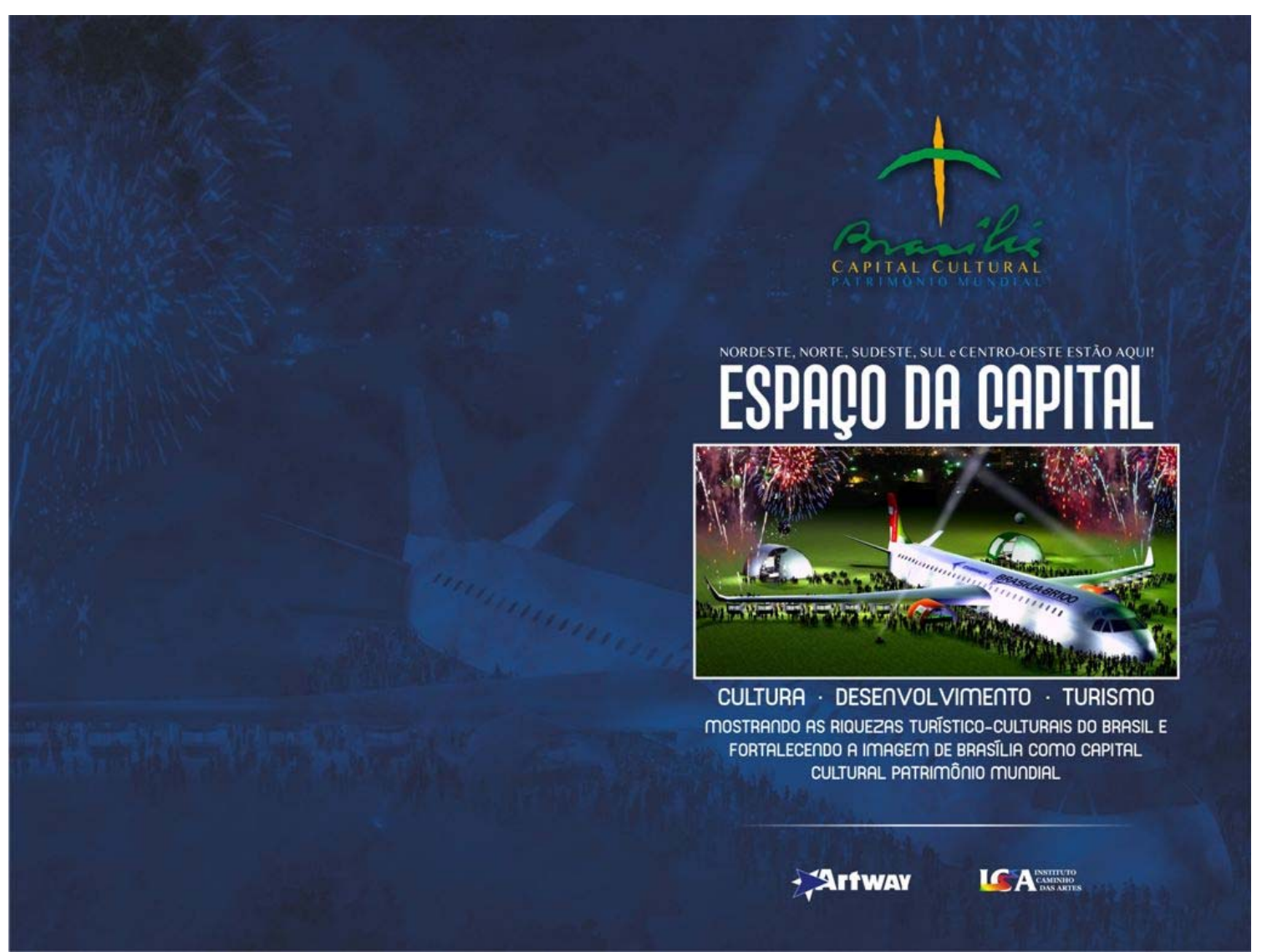


Apresentação

Um Centro de Eventos Multimídia no formato arquitetônico de Brasilia

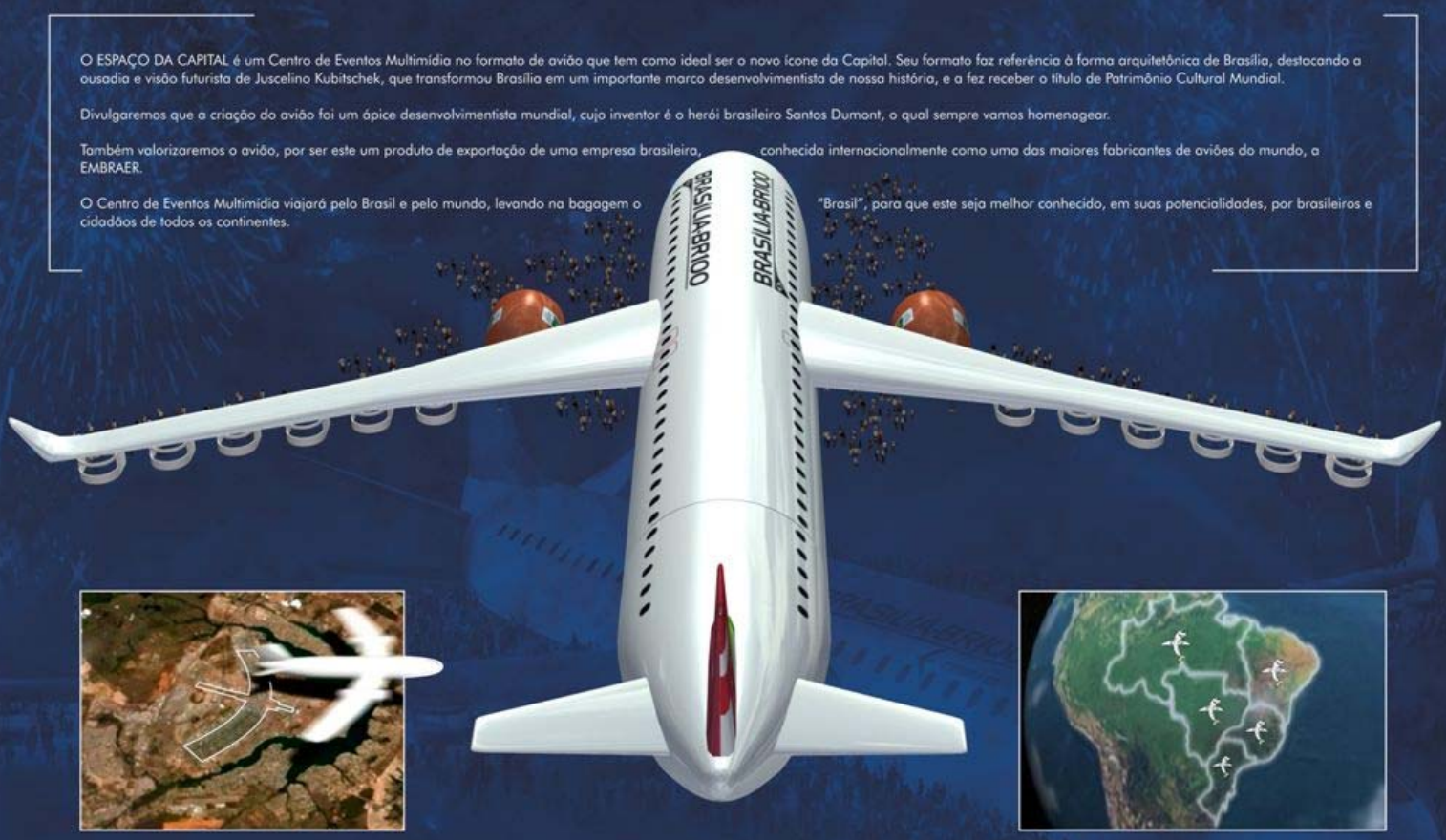

Bnavilis

Objetivos

Promoveremos uma espetacularização de nossa diversidade cultural

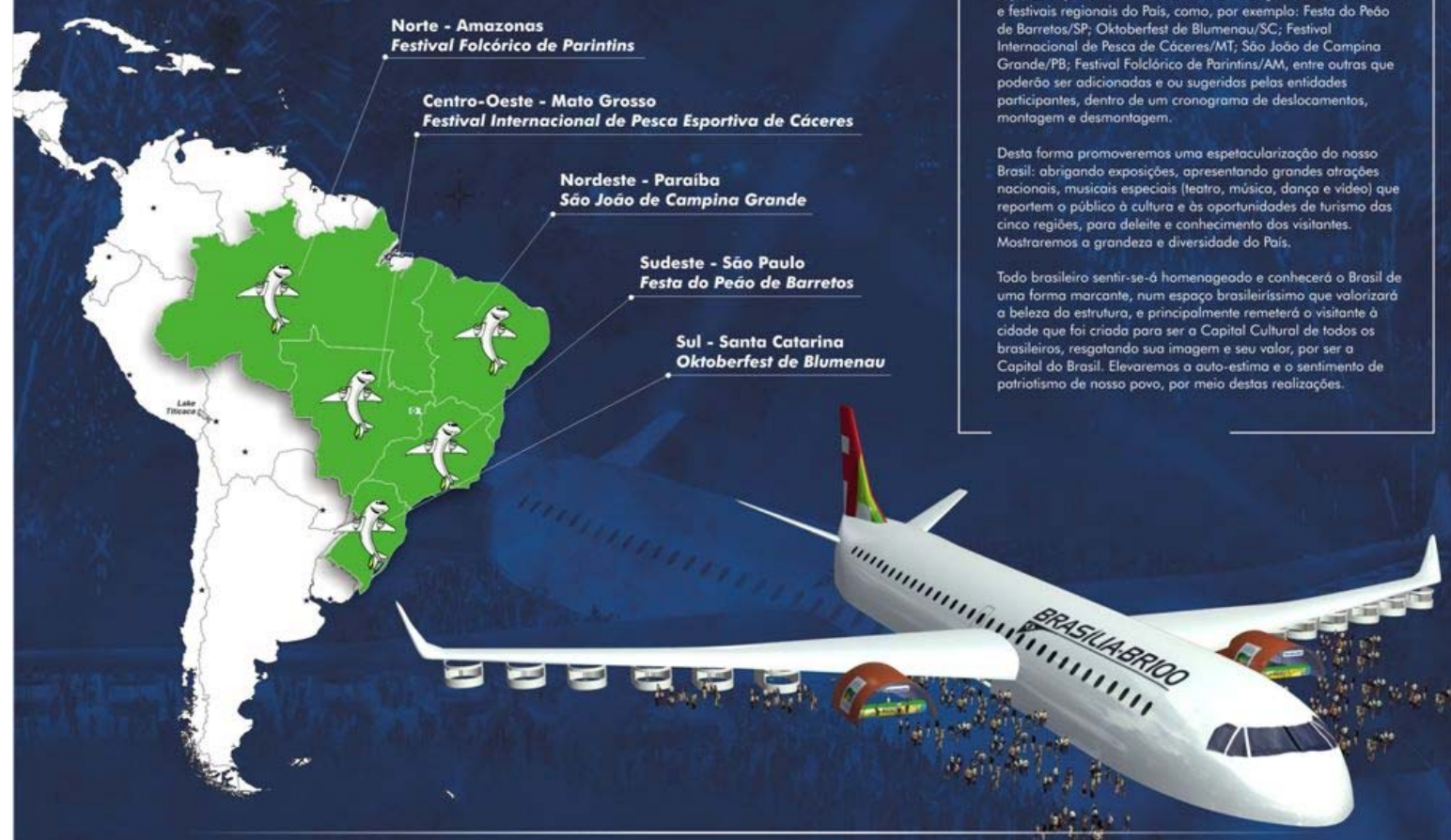

Bnavilis 
CEm - Centro de Eventos Multimídia

Uma super estrutura nunca vista dividida em sete ambientes

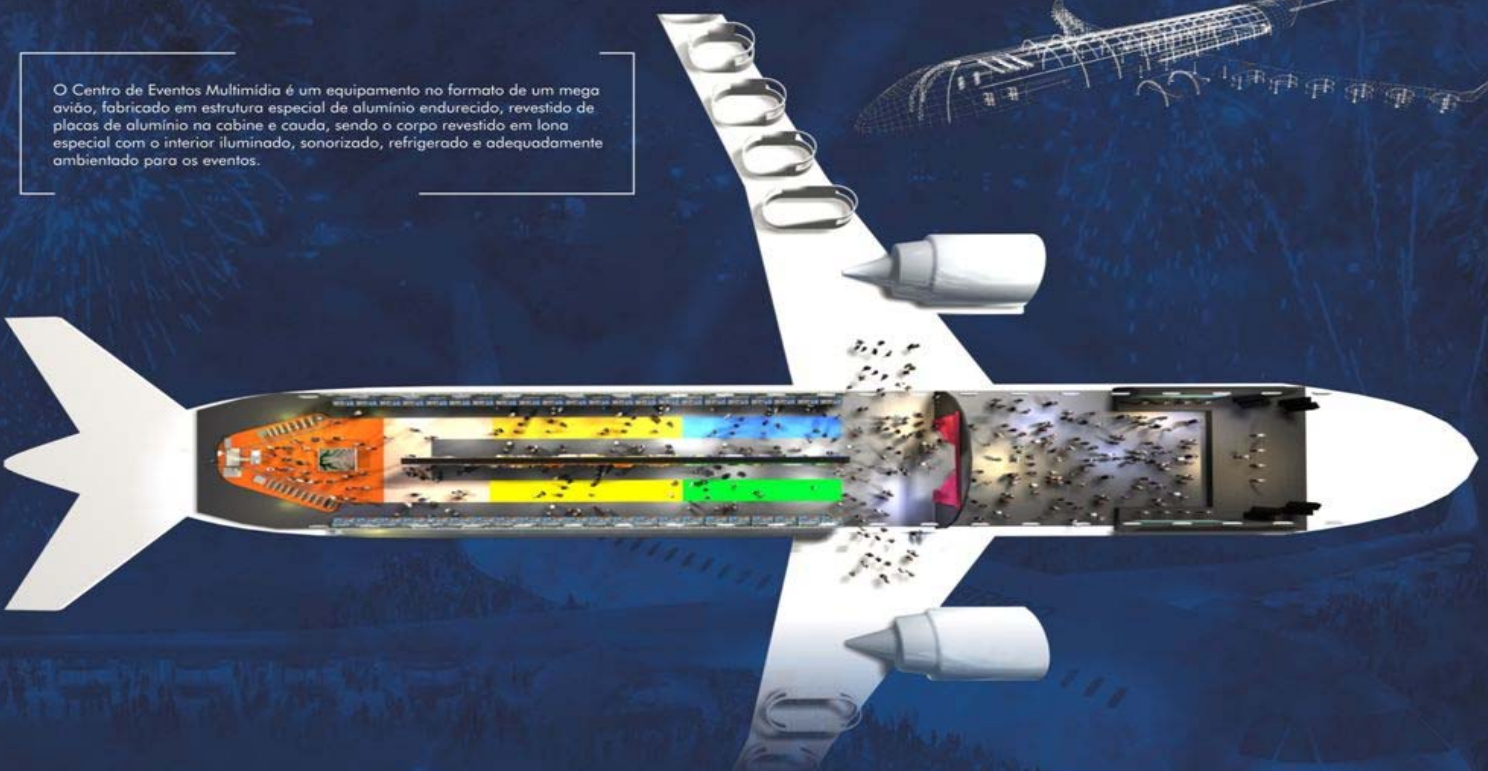

CEm - Centro de Eventos Multimídia

Uma super estrutura nunca vista dividida em sete ambientes
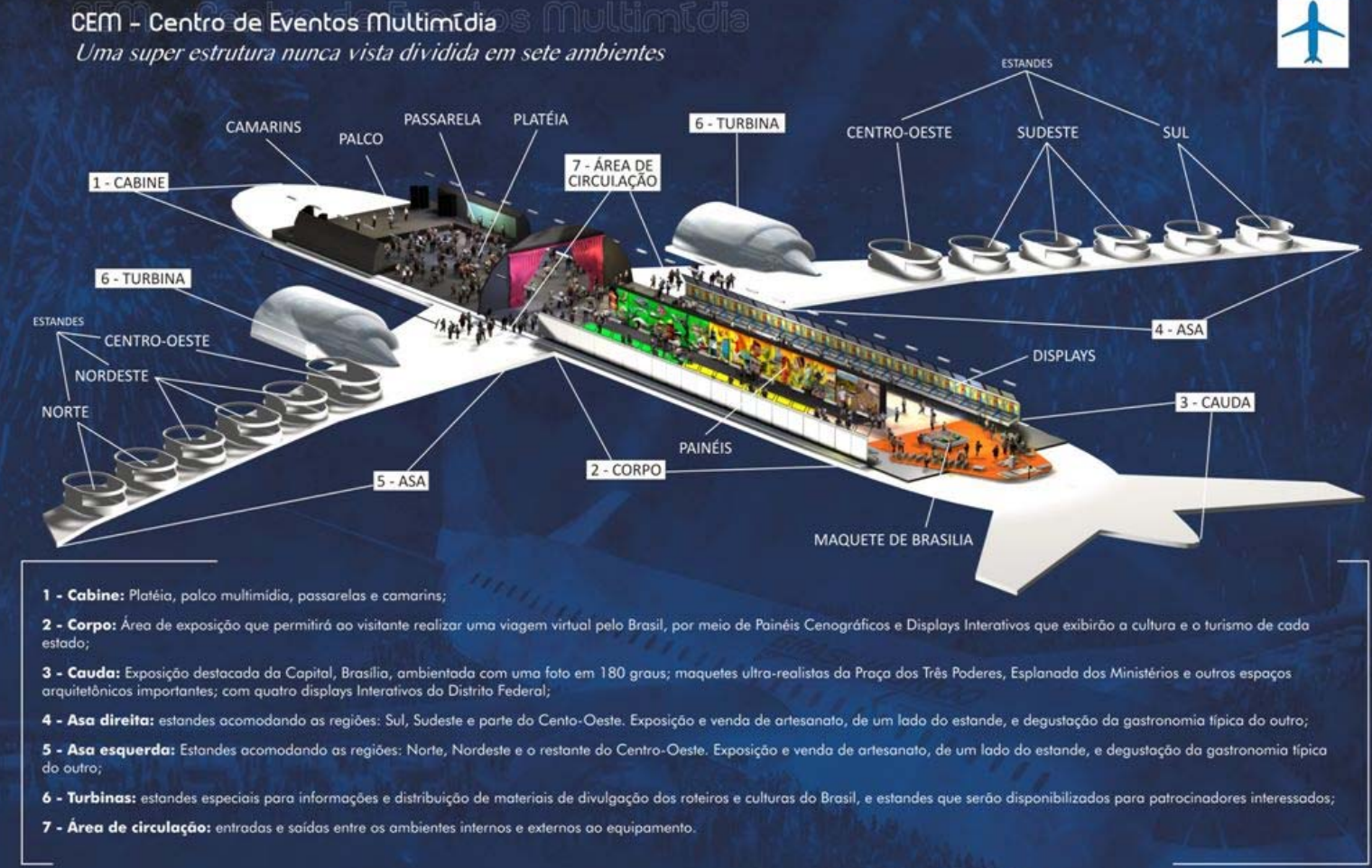
Brasitia - Br 100

O Brasil e o Mundo conhecerão o BRASILIA-BRIO0

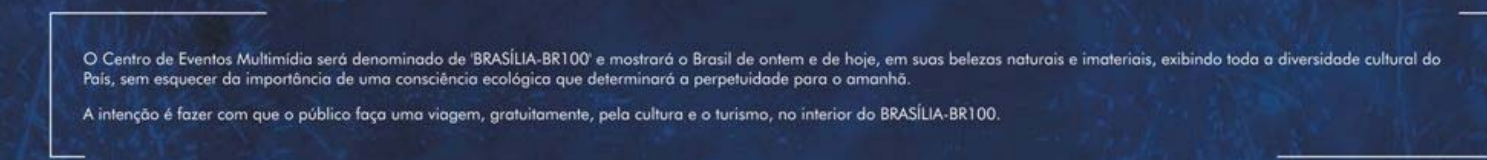

BRASILIA-BRIOO

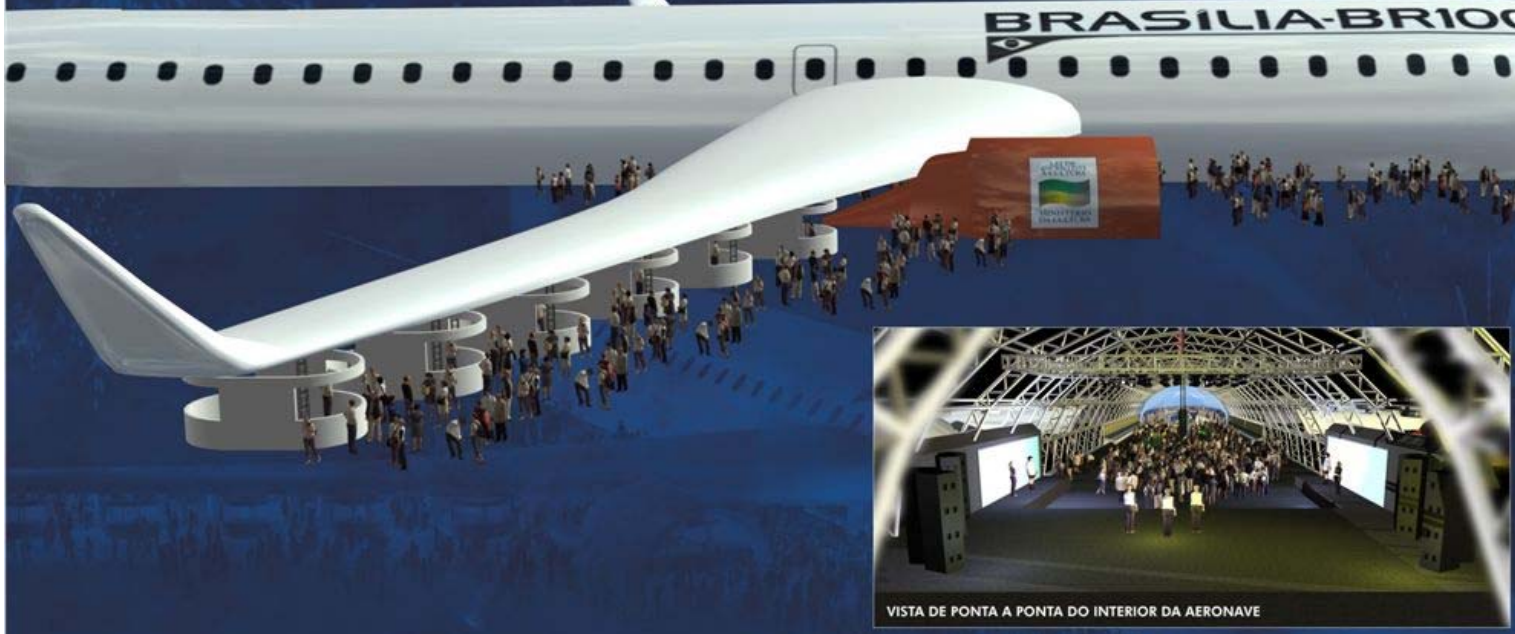

Bramili:

Cabine - Teatro multimídia

Espetáculos inesqueciveis que encantarão a todos os presentes

-

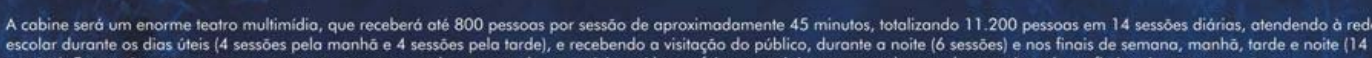
sessóes). Este sera um espaço para apresentaçoes que mesclam teatro, dança, musica, video e efeilos especiais, apresentados por duas equipes de profilssionais que revezaráo as

Neste teatro haveró um palco ao fundo, com os extremidades laterais alongados, com telas entrecortados, de tecido elástico, de onde os artistas sairóo, causondo surpresa no público. Ac (a)

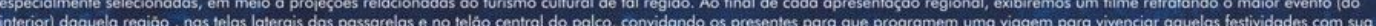
familia e amigos.

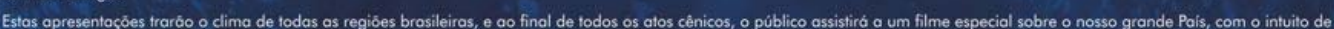
despertar o interesse em todos, de conhecer o Brosil por inteiro, desfrutando de nossa cultura e de nosso furismo, berm como, de conhecer as empresas e as instituiç̄es que proporcionarom a construçāo do equipamento, a viabilizoçáo da furnê para oquela localidade, dentre tantas outros

Nosso foco principal será fozer o papel inverso das manchetes negativas veiculados pela imprenso... Volorizoremos tudo de bom que existe e é produzido no Pois, objetivando elevor a outoestima do povo e promover uma espetacular açáo, exibindo o Brosil que dá certo.
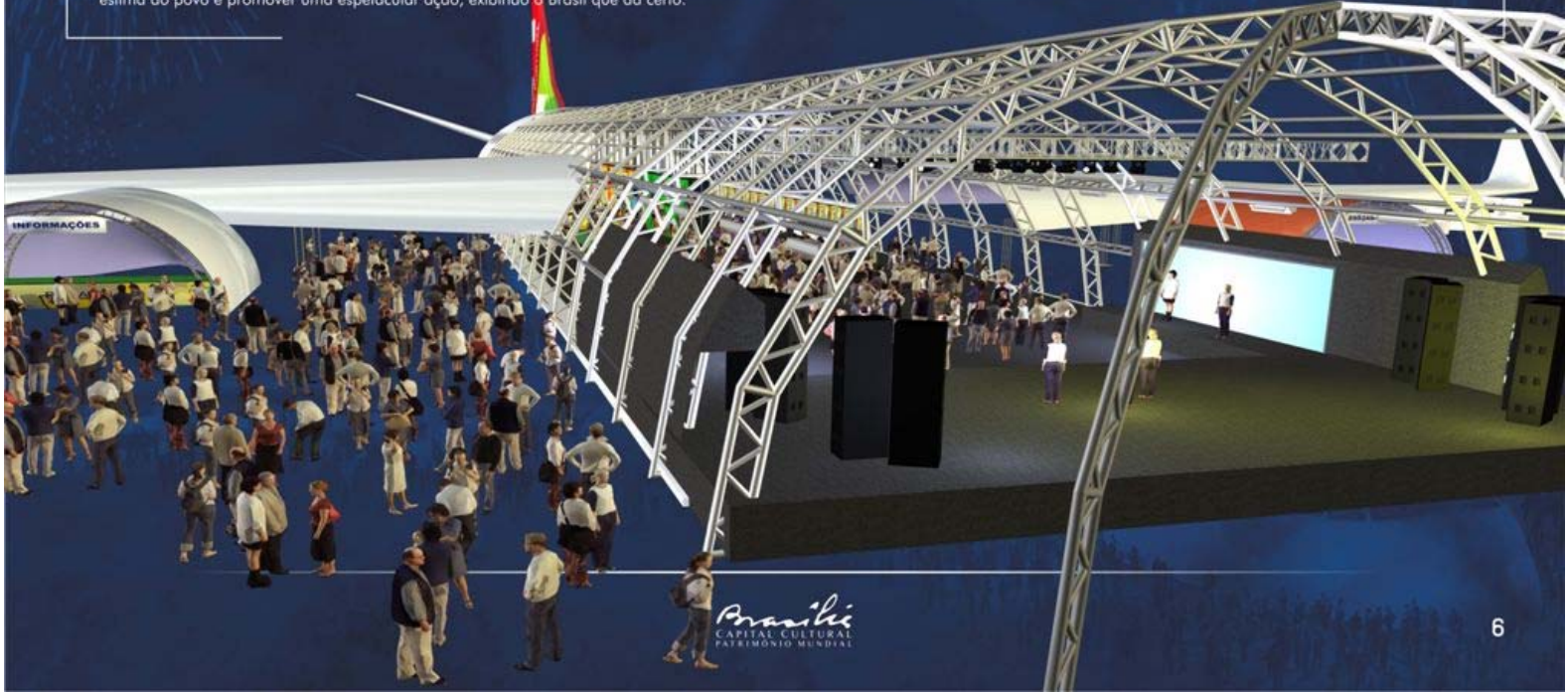
Cabine - Teatro multimídia

Musical especialmente elaborado para emocionar a platéia

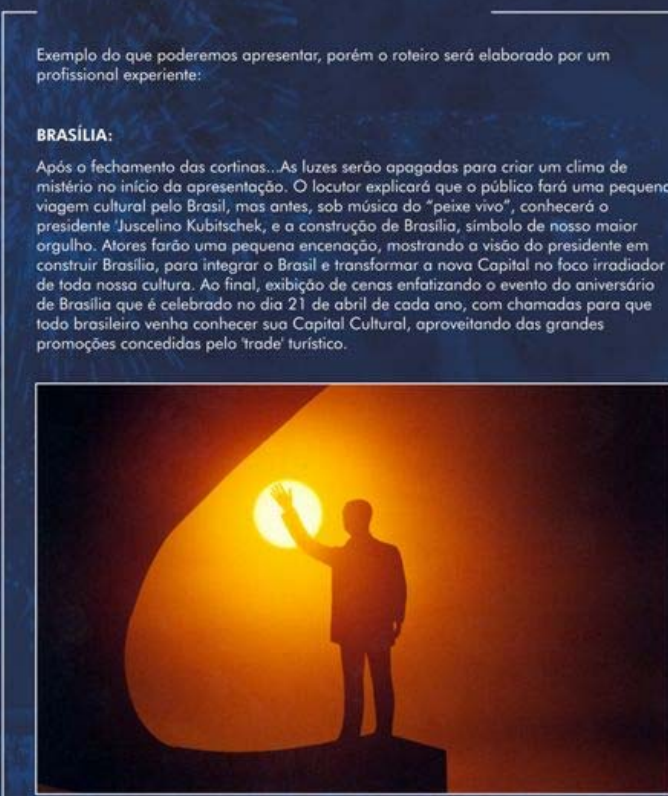

CENTRO-OESTE:

O Centro-Oeste seŕa retrotado com cantigas de Viola de Cocho', empregada pelo homem do compo, referindo-se a uma tora de madeira escavada, formando uma espécie de recipiente com a funç̧áo de olimentar animais domésticos. Goías farć a

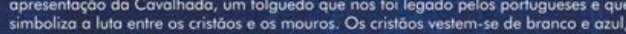
cores do cév e da pureza, com espodas retas que simbolizam a retidáo da justiça. Os mouros, de vermelho e verde, cores da chama do inferno das amarguras, com espadas Érvas simbolizando o mol. Éroda grupo procura trajar-se mais ricamente que o outro seróo representados por tiguras de paus com cabeça. Também dançada em Goías, Volia Senhora, que é uma quadrilha que faz parte dos diversos motivos do Fandango, $e$

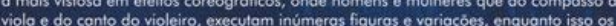
dancadores sáo sempre ligados entre si por lenços ou paus opropriados. Ao finol exibiç̧óo de cenos com chamados enfatizando um dos principais eventos do interior do Cento-Oeste o 'Festival Internacional de Pesca Esportiva de Cáceres/MT que é promovidos no més de setembro de cada ano.
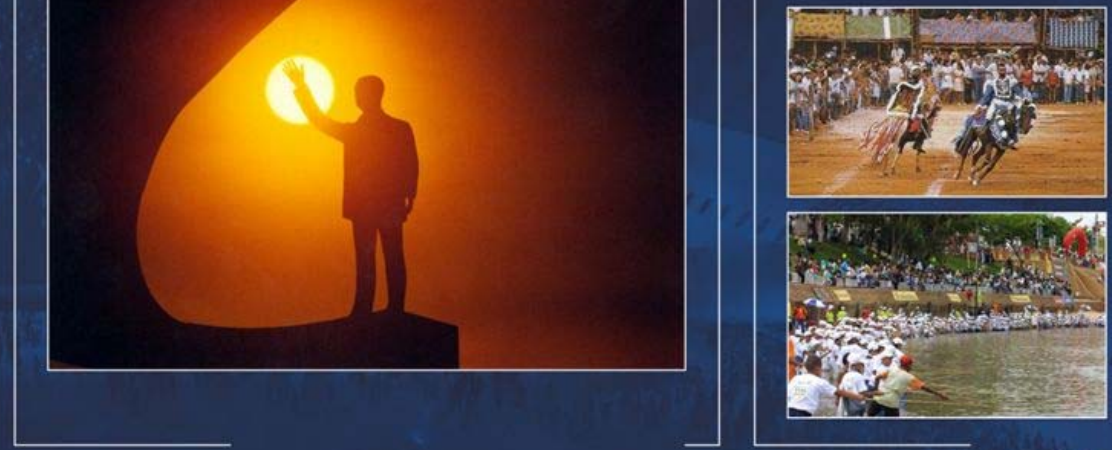

Cabine - Teatro multimídia

Musical especialmente elaborado para emocionar a platéia
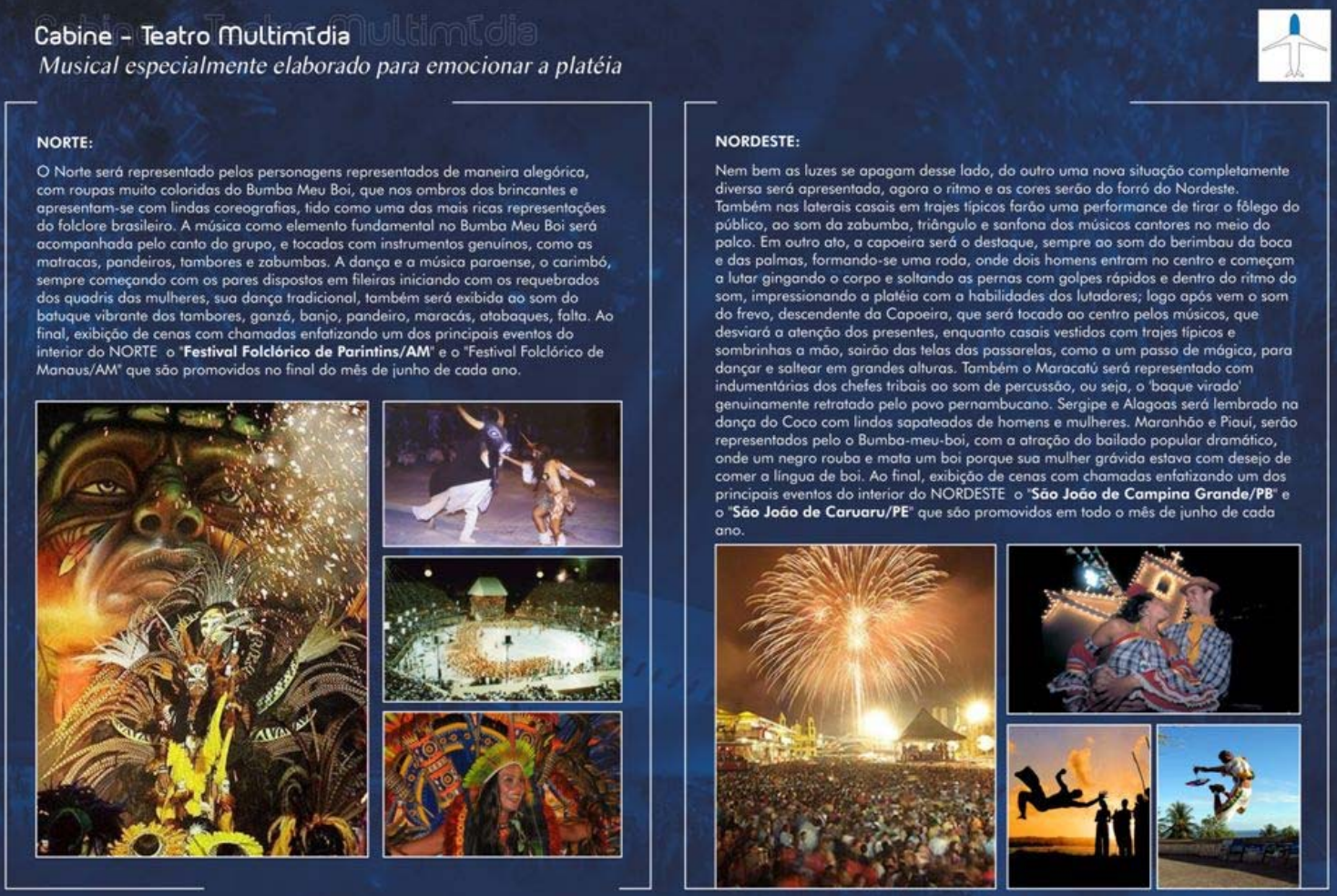
Cabine - Teatro multimídia

Musical especialmente elaborado para emocionar a platéia

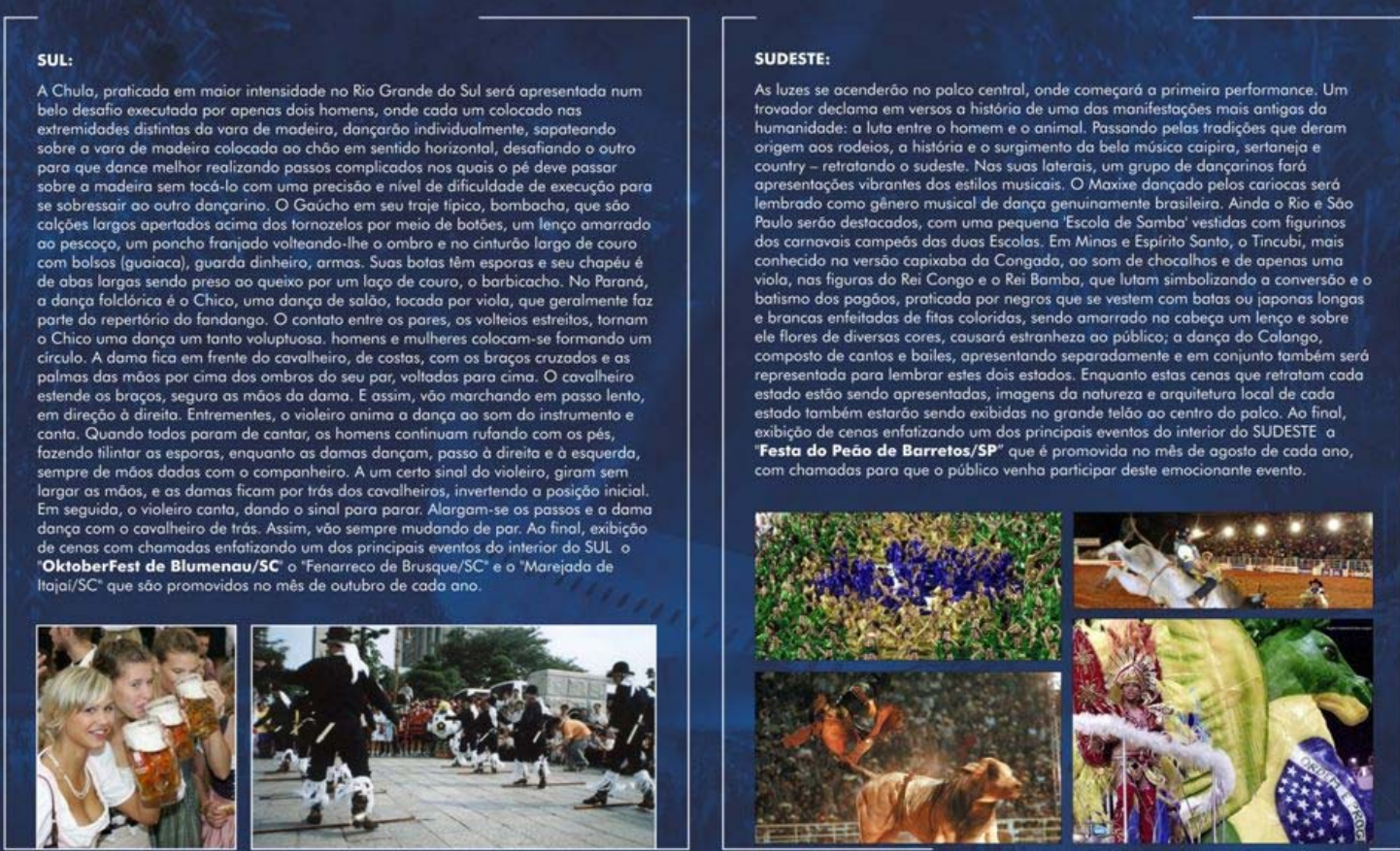

Bnatis

Corpo - Uma viagem virtual

Mostraremos as belezas do nosso País em detalhes primorosos
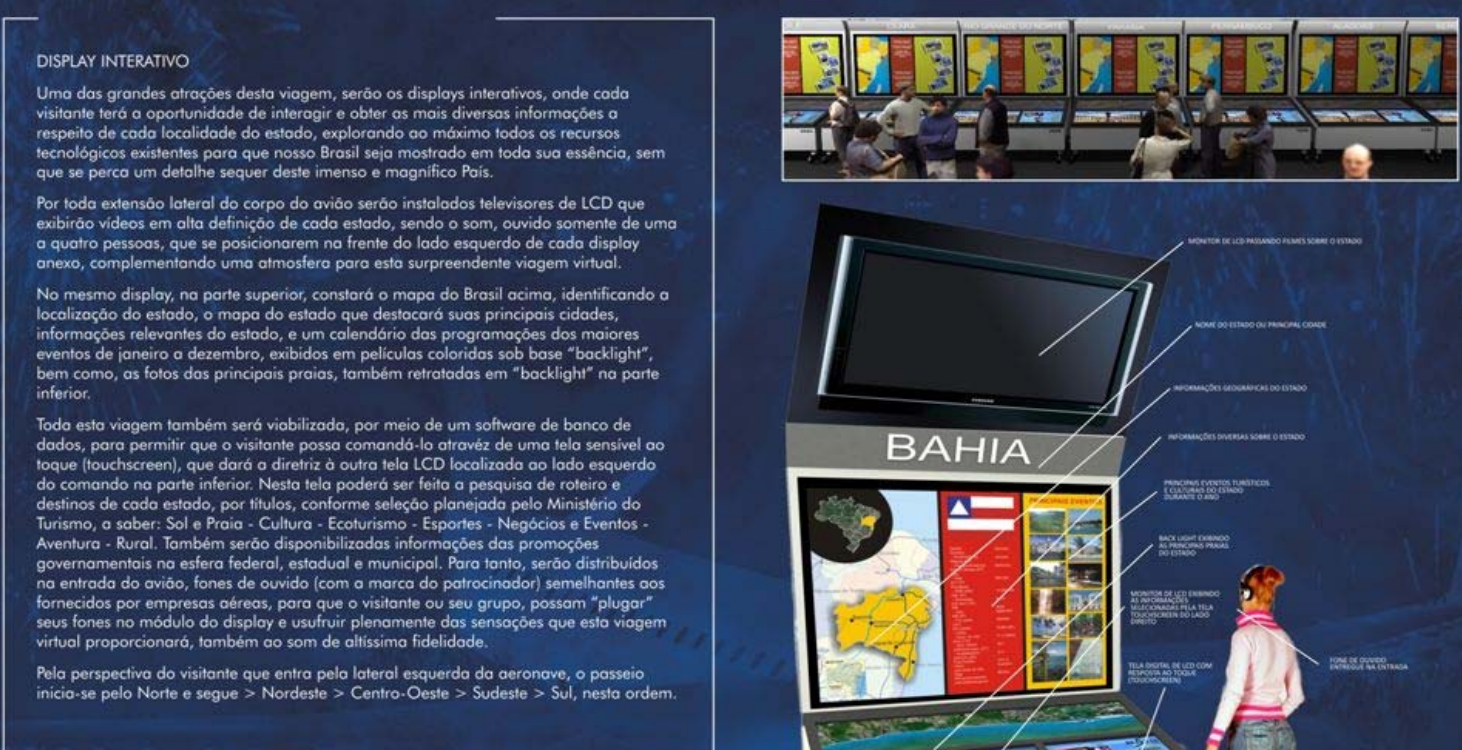

BAHIA

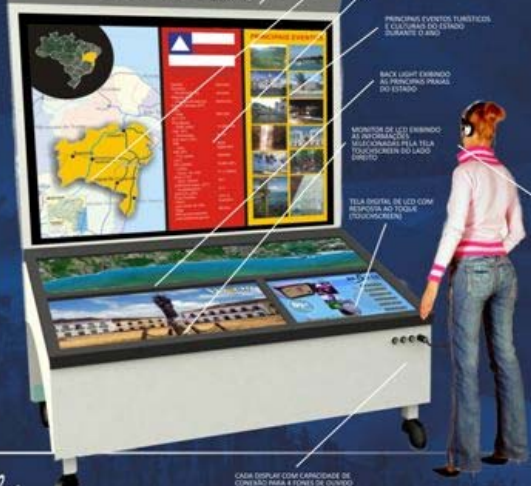

Bnathi 
Corpo - Uma viagem virtual

Lindos painéis em alto relevo elevarão ainda mais o clima desta viagem

-

PAINEL CENOGRAFICO

Na area centrai desse espaço, será instalados grandes cenários produzidos com imagens em alio relevo dos principais icones de cada regiáo, retratando arquitetura, belezos naturois

esculturos, figuras folclóricas, costumes, e cores da nossa cultura, tudo isso anexado a grandes painéis removiveis.

O público notará a correspondência geogrófica entre um lado e outro do cviỏo, percebendo que está fazendo um passeio em cado uma das regióes brosileiros.
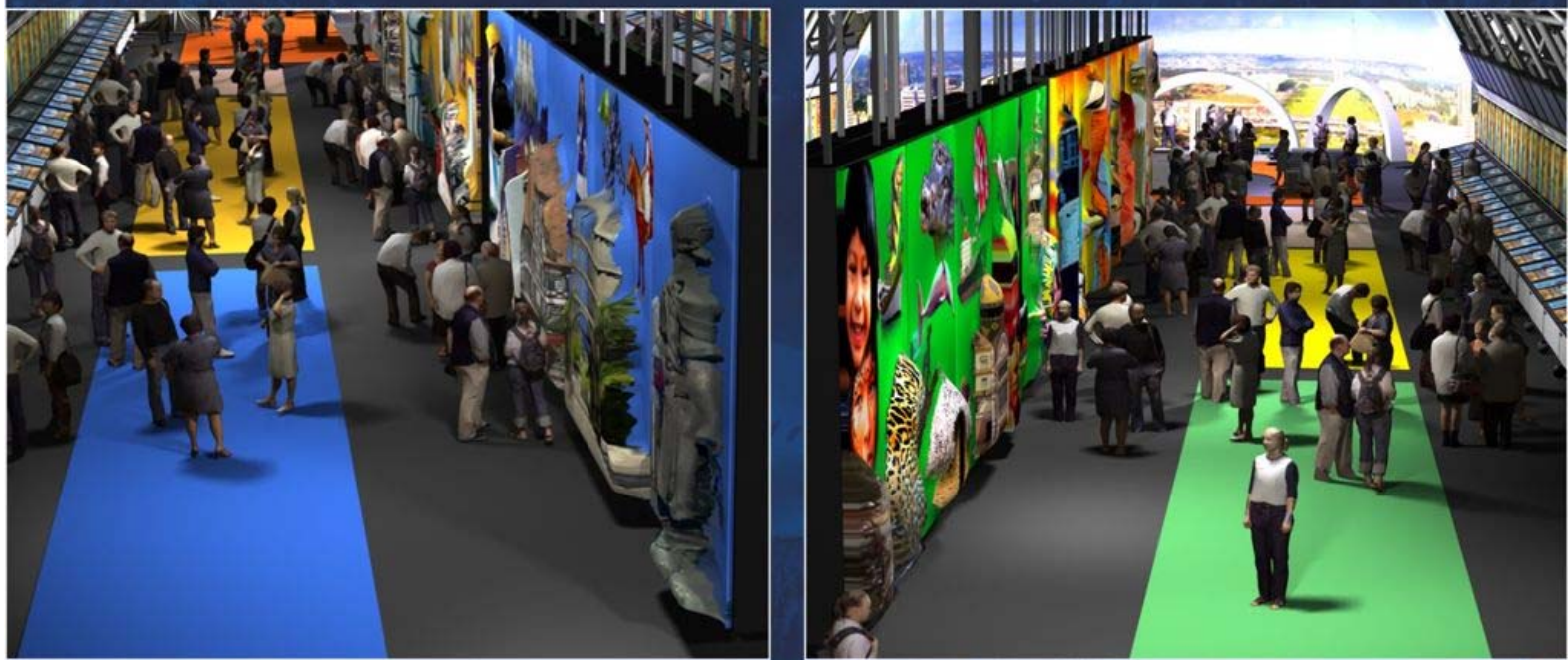

Bravili:

Asas - Cores e sabores

Lindos painéis em alto relevo elevarão ainda mais o clima desta viagem

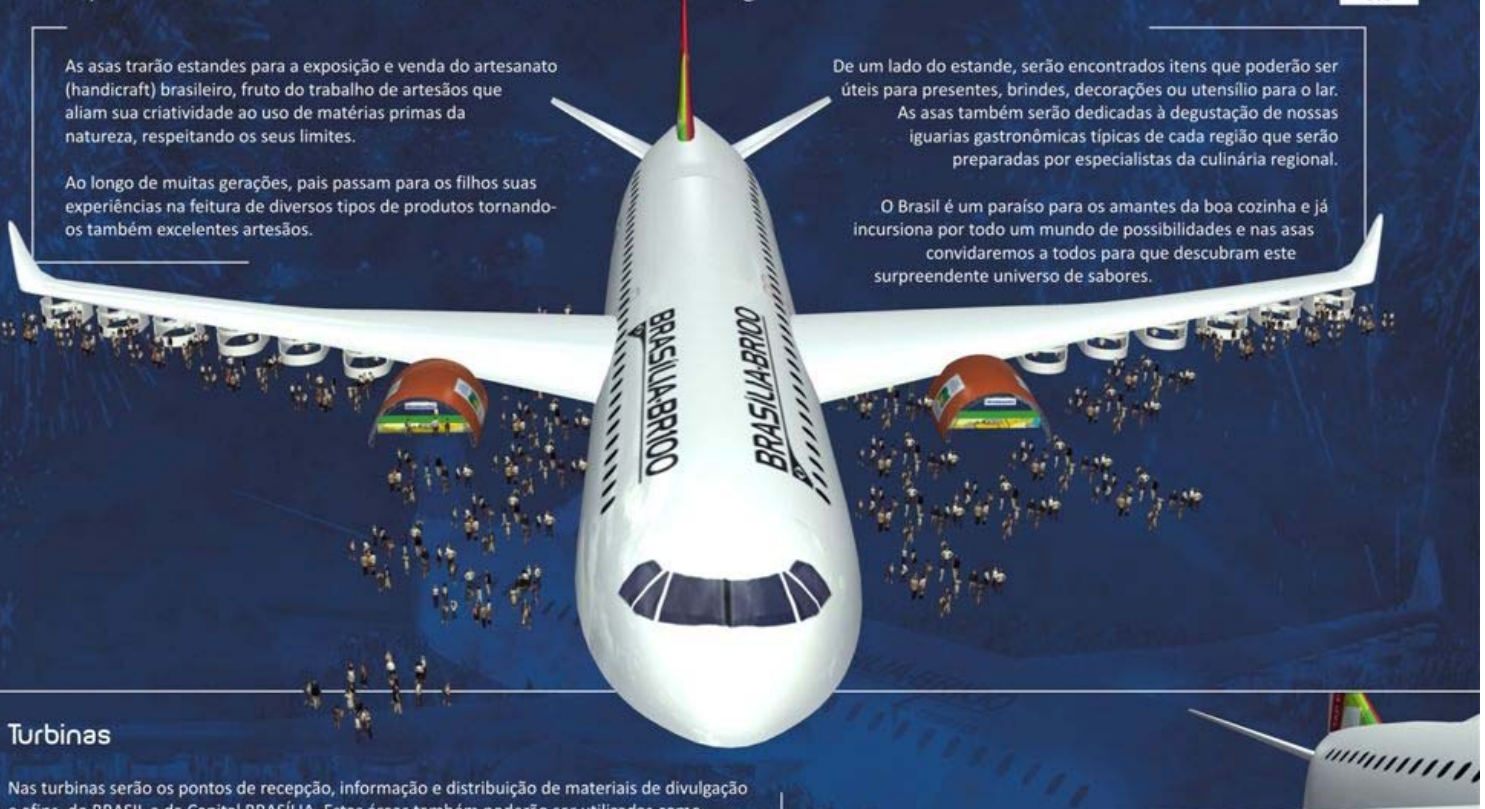
e afins, do BRASIL e da Capital BRASílLA. Estas áreas também poderão ser utilizadas como estandes especiais dos patrocinadores do evento.

$$
\text { int }
$$


Cauda - Brasília, Capital Cultural

Brasilia terá espaço especial onde todos poderão conhecer sua história e belezas arquitetônicas

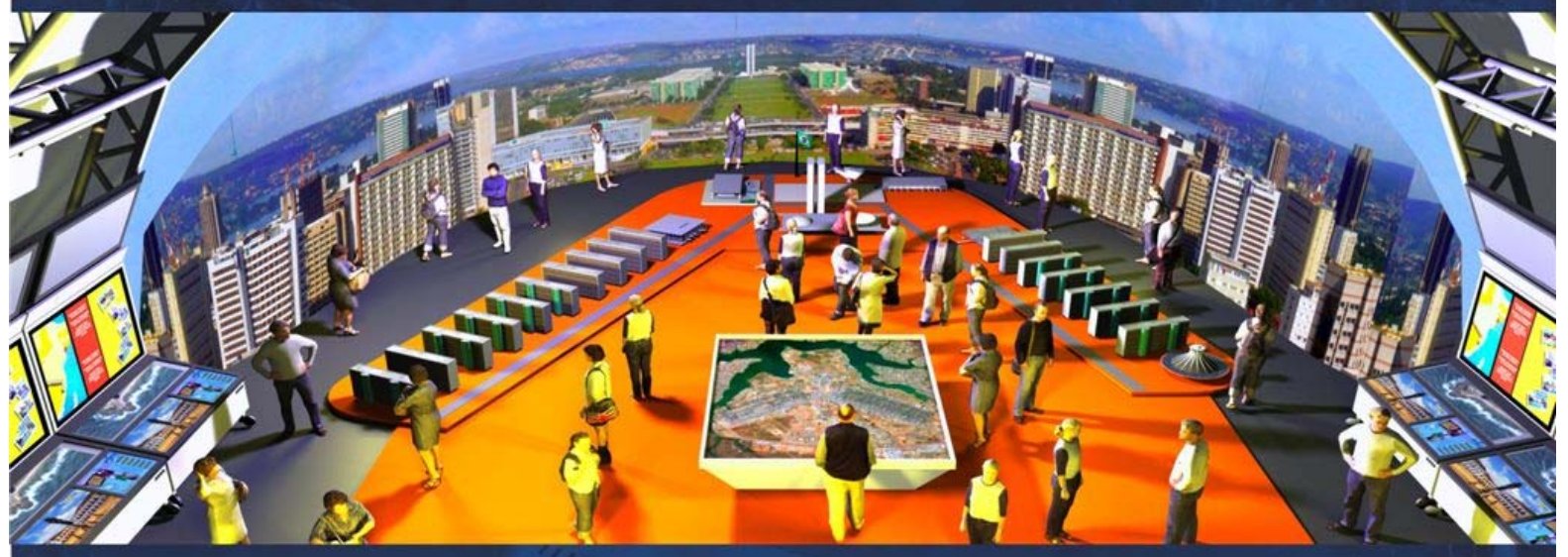

couda sera o local exclusivo para expormos Brosilio, onde será é,

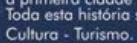

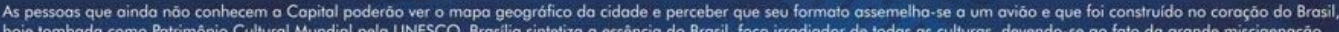

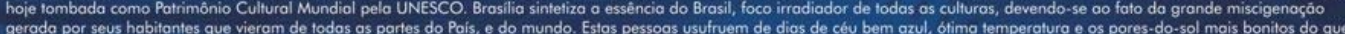
geroda por seus habitiontes
em qualquer outra cidode.

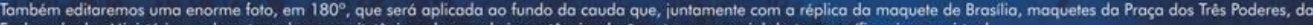

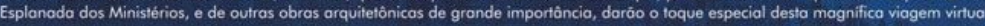

Bnavili:

Encerramento do Evento

Com uma grande festa encerraremos a presença do BRASÍLIA-BR 100 na cidade
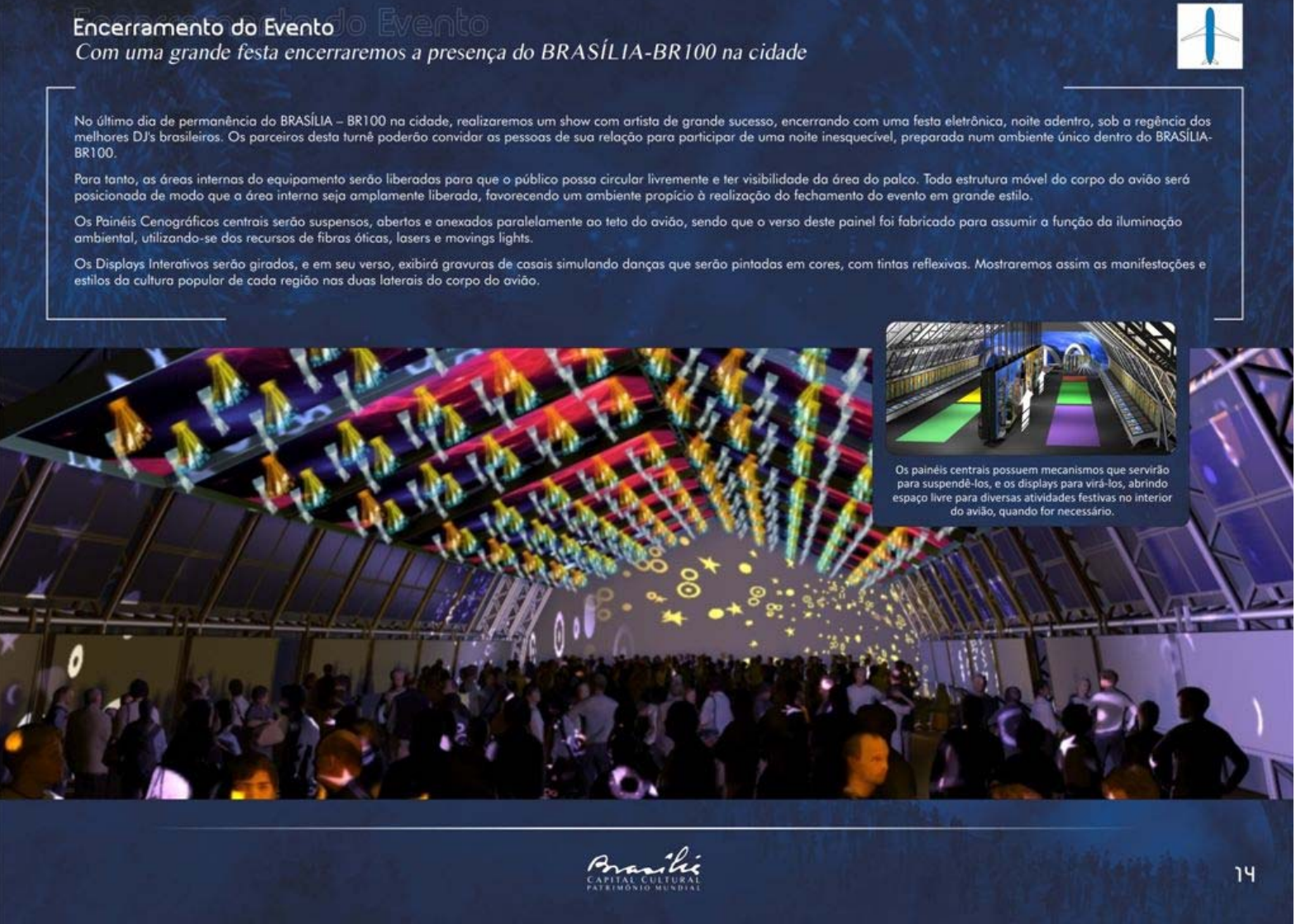
Planta baixa

Uma estrutura surpreendente, identificada com a Capital Cultural

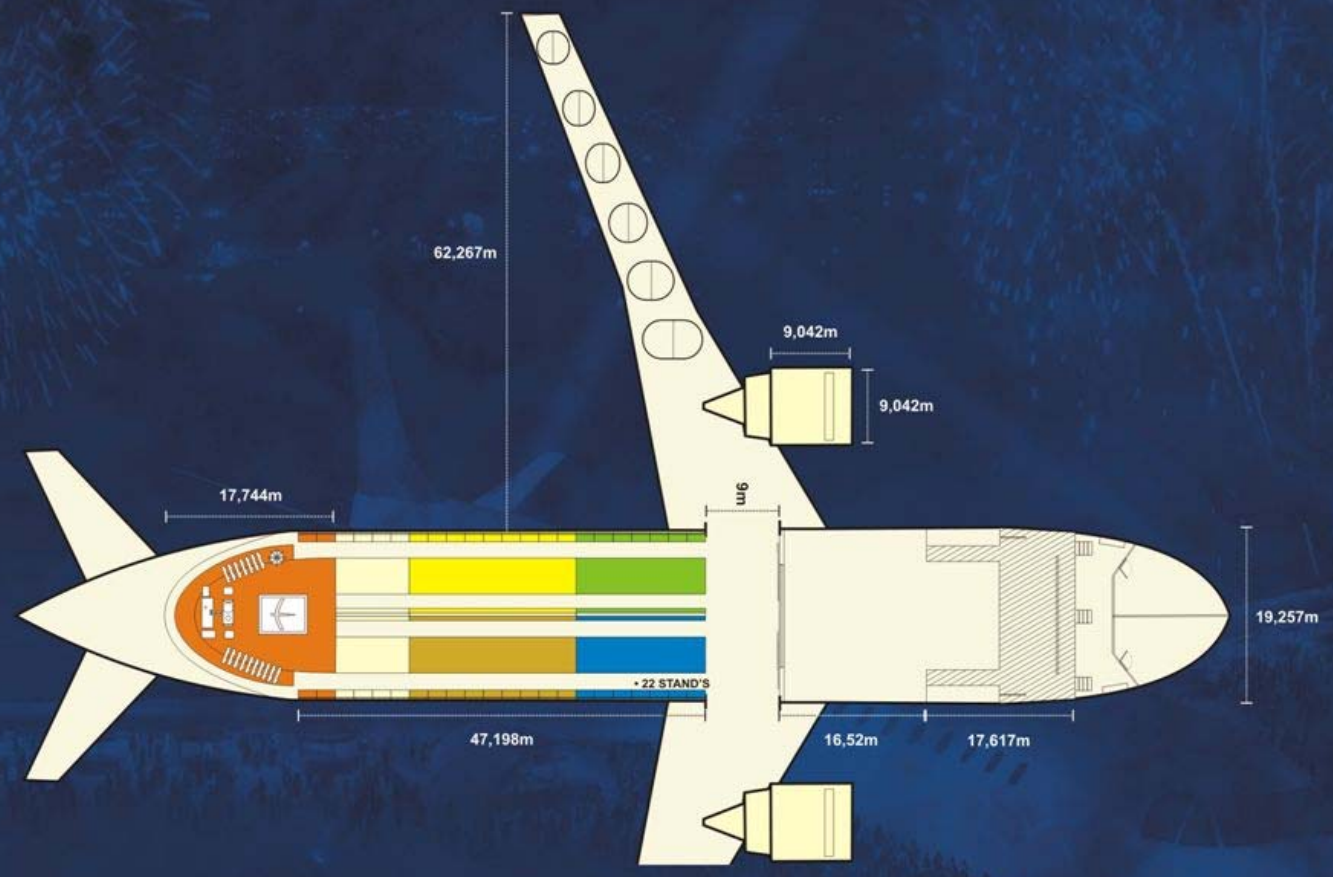

Bnavilis

Viagens Internacionais - Salão Brasil

o Centro de Eventos Multimídia fará "vôos" pelo mundo, encantando cada País pelo nosso potencial turístico-cultural e por nossa fama de bons anfitriōes

下

A cobine será um enorme teatro multimidia, que receberá oté 800 pessoas por sessóo de aproximadamente 45 minutos, totolizando 11.200 pessoas em 14 sessóes diários, otendendo a rede escolar durante os dias úteis (4 sessóes pela monhá e 4 sessóes pela tarde), e recebendo a visitoçáo do público,

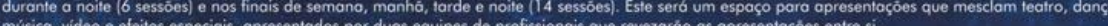

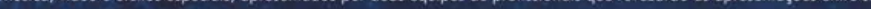

Neste featro, hoverá um palco ao fundo, com as extremidades laterais alongadas, que terâo telas entrecortados, de fecido elóstico, de onde os artistos a surpresa no público. Ao longo das apresentaçóes paro cada espetóculo cênico que retratará a cultura popular e folclore regional, os atores e músicos faróo suas performances acompanhadas por músicas especialmente selecionadas em meio a projęçóes relacionadas ao turismo cullural de cada regiáo. Ao final de cada apresentaçao regional exibiremos um filme do moior evento do interior, nas telas laterais das passarelas e no teláo cent do palco, convidando-os para que programem uma viagem para vivenciar aqueles momentos com sua familia ou amigos.

Estos opresentaçóes traróo o clima de todas as regibes brosileiros, e ao final de todos os atos cênicos, o público assistiría a um filme especial sobre o nosso grande Pais, com o intuito de despentar o interesse em lodos, de conhecer o Brosil por inteiro desfrutando de nossa cultura e de nosso turismo, bem como, de conhecer as empresas e as instituiçóes que proporcionaram o construçáo do equipamento e a viabilizaç̧o da furné para oquele localidade dentre tontas outros.

Nosso foco principol será fazer o popel inverso das manchetes negativas veiculodas pela imprensa... Volorizaremos tudo de bom que existe e é produzido no Pais, objetivando elevar a autoestima do povo e promovendo uma espetacular açăo do Brasil que dá cern.
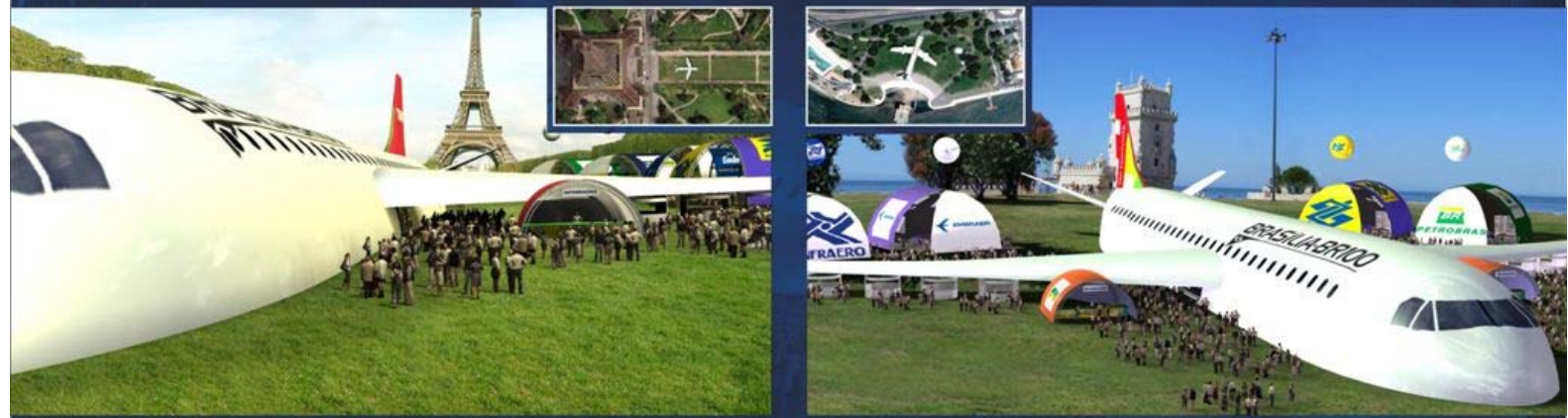


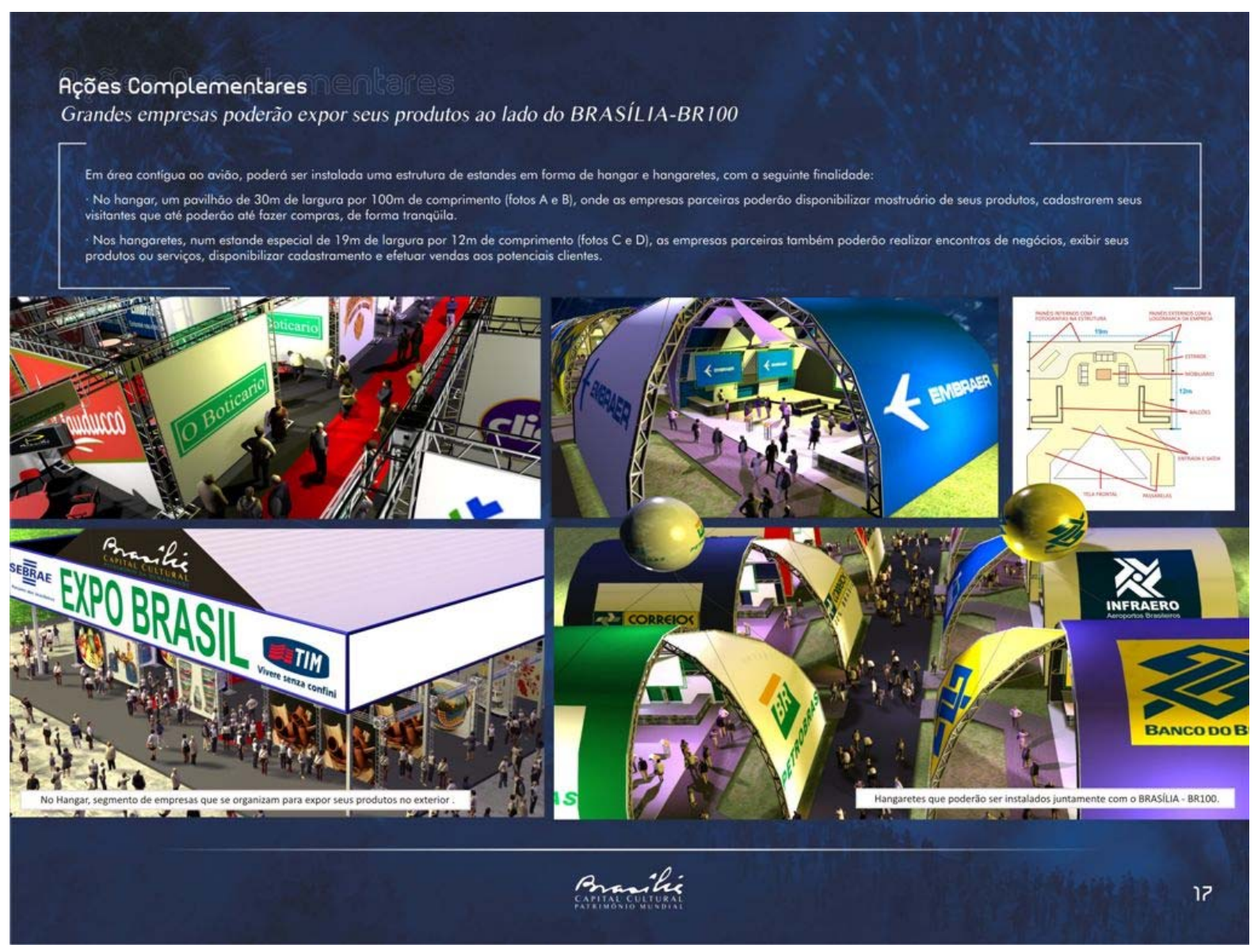




\section{Apêndice D - Tabela de preços Sugerida a Rede Hoteleira}

\section{Hotel do Distrito Federal}

\section{Sugestão de preços para finais de se- mana}

Venda de hospedagem à população com desconto para vir a Brasília no período do Festival.

Proposta:

.Divulgação publicitária de campanha do Brasília Capital Cultural do Nordeste;

.Promoção nas principais cidades e capitais de cada estado nordestino;

.Hospedagem com valor promocional, com valores de pacote por pessoa,

condicionado a quarto duplo, com aumento tarifário de $\mathrm{R} \$ 10,00$ por pessoa,

a cada dia fora do pacote (pacote de 3 dias);

\begin{tabular}{|l|l|l|l|l|}
\hline \multicolumn{4}{|l|}{ Hotel 3 estrelas } & \multicolumn{2}{l|}{ Apartamentos } \\
\hline No Dias & $\begin{array}{l}\text { Pre- } \\
\text { ço/Pess }\end{array}$ & Single & Duplo & Triplo \\
\hline 3 & $\mathrm{R} \$ 40,00$ & $\mathrm{R} \$ 140,00$ & $\mathrm{R} \$ 140,00$ & $\mathrm{R} \$ 360,00$ \\
\hline 2 & $\mathrm{R} \$ 50,00$ & $\mathrm{R} \$ 200,00$ & $\mathrm{R} \$ 200,00$ & $\mathrm{R}$ 300,00 \\
\hline 1 & $\mathrm{R} \$ 60,00$ & $\mathrm{R} \$ 120,00$ & $\mathrm{R} \$ 120,00$ & $\mathrm{R} \$ 180,00$ \\
\hline
\end{tabular}

\begin{tabular}{|l|l|l|l|l|}
\hline \multicolumn{2}{|l|}{ Hotel 4 estrelas } & \multicolumn{2}{l|}{ Apartamentos } & \\
\hline No Dias & $\begin{array}{l}\text { Pre- } \\
\text { ço/Pess }\end{array}$ & Single & Duplo & Triplo \\
\hline 3 & $\mathrm{R} \$ 50,00$ & $\mathrm{R} \$ 200,00$ & $\mathrm{R} \$ 200,00$ & $\mathrm{R} \$ 300,00$ \\
\hline 2 & $\mathrm{R} \$ 60,00$ & $\mathrm{R} \$ 120,00$ & $\mathrm{R} \$ 120,00$ & $\mathrm{R} \$ 180,00$ \\
\hline 1 & $\mathrm{R} \$ 70,00$ & $\mathrm{R} \$ 140,00$ & $\mathrm{R} \$ 140,00$ & $\mathrm{R} \$ 210,00$ \\
\hline
\end{tabular}

\begin{tabular}{|l|l|l|l|l|}
\hline \multicolumn{2}{|l|}{ Hotel 5 estrelas } & \multicolumn{2}{l|}{ Apartamentos } \\
\hline No Dias & $\begin{array}{l}\text { Pre- } \\
\text { ço/Pess }\end{array}$ & Single & Duplo & Triplo \\
\hline 3 & $R \$ 60,00$ & $R \$ 120,00$ & $R \$ 120,00$ & $R \$ 180,00$ \\
\hline 2 & $R \$ 70,00$ & $R \$ 140,00$ & $R \$ 140,00$ & $R \$ 210,00$ \\
\hline 1 & $R \$ 80,00$ & $R \$ 160,00$ & $R \$ 160,00$ & $R \$ 240,00$ \\
\hline
\end{tabular}




\section{ANEXOS}

\section{Anexo A: Empregabilidade do Turismo no País.}

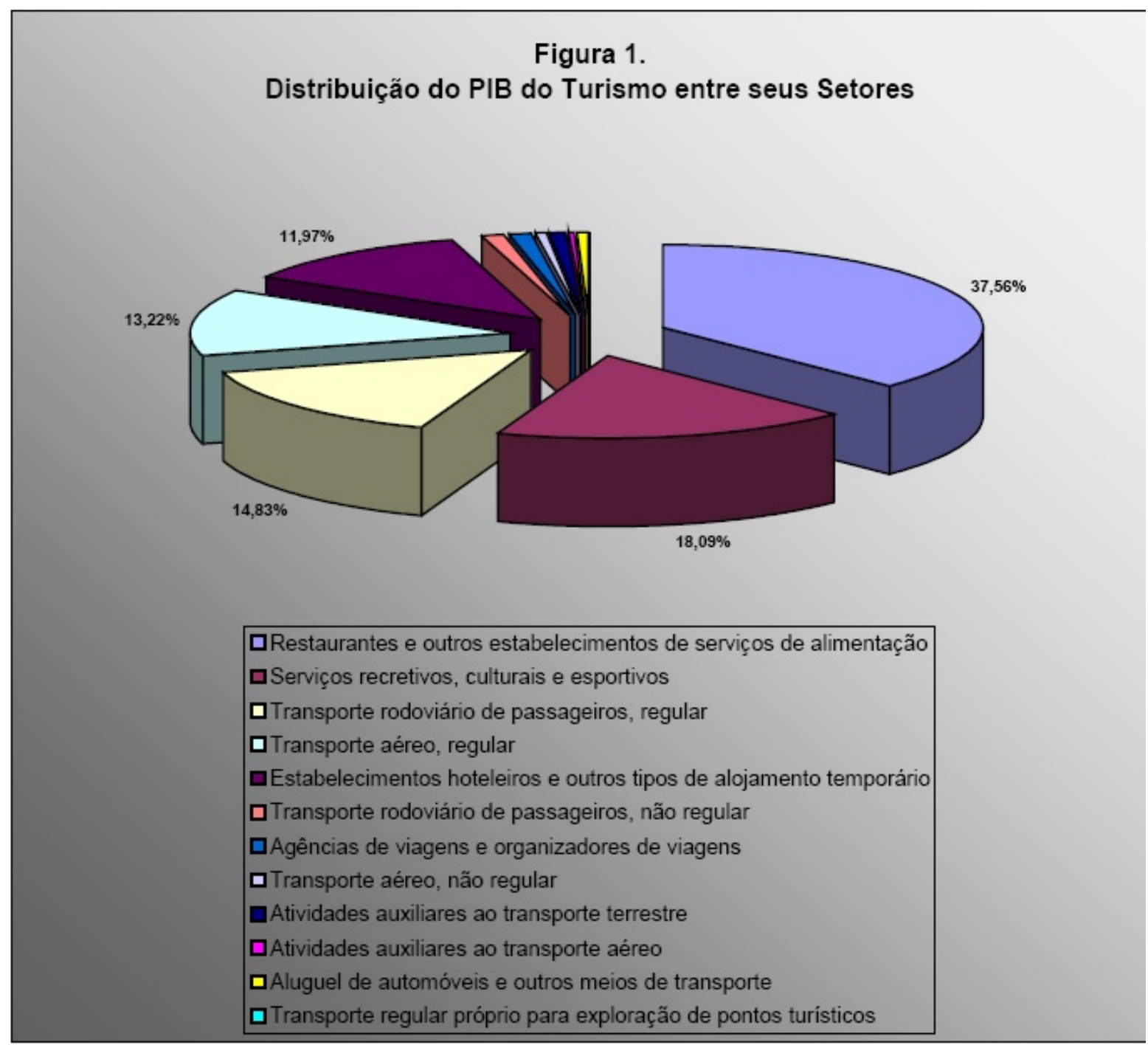

\section{"Turismo emprega 4,4 milhões no país".}

O número de empregados formais e informais no setor de turismo no país cresceu 24\% entre 1992 e 1999. Com isso, o número de profissionais que atuam nessa área de forma direta passou para 4,4 milhões. É o que mostra a pesquisa Perfil dos Profissionais do Mercado de Trabalho do setor de turismo no Brasil, elaborada pelo Instituto de Hospitalidade.

Apesar da expansão, cujo percentual superou em muito os 10\% de crescimento da economia, apenas 6,1 \% da População Economicamente Ativa (PEA) trabalha em 
áreas ligadas ao turismo. Em países da Oceania, esse porcentual chega a 14\% e nos Estados Unidos, a 12,6\%.

Os hotéis e pousadas são os que mais empregam trabalhadores com carteira assinada: cerca de 70\%. Já nas agencias de viagem, empresas de turismo e transportes esse porcentual cai para 50\%. Bares, restaurantes e atividades de entretenimento e lazer são tipicamente informais, pois pouco mais de $20 \%$ dos profissionais têm carteira assinada.

A remuneração média no mercado de trabalho brasileiro para esse setor é de $R \$$ 428,00. Os profissionais empregados nas agencias de turismo recebem a melhor remuneração média para o setor segundo o levantamento: $\mathrm{R} \$ 837,00$. As atividades de transporte ( $R \$ 626,00)$ e entretenimento e lazer $(R \$ 605,00)$ aparecem em segundo e terceiro lugar, respectivamente, na média salarial desses profissionais. 


\title{
Anexo B: Calendário Oficial de Eventos de Brasília - Lei 3.328/04.
}

\author{
LEI No 3.328, DE 23 DE MARÇO DE 2004.
}

(Autor do Projeto: Deputado Distrital Leonardo Prudente)

Inclui no Calendário Oficial de Eventos de Brasília o Projeto Brasília Capital Cultural. O Presidente da Câmara Legislativa do Distrito Federal promulga, nos termos do § $6^{\circ}$ do art. 74 da Lei Orgânica do Distrito Federal, a seguinte Lei, oriunda de Projeto vetado pelo Governador do Distrito Federal e mantido pela Câmara Legislativa do Distrito Federal:

Art. $1^{\circ}$ Fica incluída no Calendário Oficial de Eventos de Brasília a programação denominada Projeto Brasília Capital Cultural, em homenagem a cada região brasileira, que celebrará a diversidade cultural em grande evento em Brasília, distribuídas anualmente da seguinte forma:

I - O Centro-Oeste está aqui!;

II - O Nordeste está aqui!;

III - O Norte está aqui!;

IV - O Sudeste está aqui!;

$\checkmark$ - O Sul está aqui!;

VI - O Brasil está aqui!.

Art. $2^{\circ} \mathrm{Na}$ realização do evento, cada região prestigiada receberá, em pelo menos uma de suas grandes festas, o Espaço da Capital que proverá a visita a Brasília por meio de um stand multimídia contendo a história de Brasília e a imagem de capital cultural, destacada por fotos, vídeos e peças teatrais, divulgando a diversidade cultural do Brasil na capital por meio de cada região representada.

Art. $3^{\circ}$ Os eventos incluídos nessa programação terão o apoio oficial do Governo do Distrito Federal que o isentará de taxas, a que título for, reservando-lhe o direito de propor ao Conselho de Cultura do Distrito Federal outras ações visando ao estímulo e ao fomento cultural por meio de Lei de incentivo vigente à época no âmbito distrital.

Art. $4^{\circ}$ As outras ações culturais do projeto, aprovadas no Conselho de Cultura, serão estimuladas para permitir o fomento cultural e turístico para a comunidade do Distrito Federal e aos visitantes de outras regiões à capital.

Art. $5^{\circ}$ As despesas decorrentes para aplicação do disposto nesta Lei correrão à conta de dotações orçamentárias do Programa Difusão e Programação Cultural da Secretaria de Estado da Cultura e/ou Secretaria de Estado de Comunicação Social.

Art. $6^{\circ}$ Esta Lei entra em vigor na data de sua publicação.

Art. $7^{0}$ Revogam-se as disposições em contrário.

Brasília, 31 de março de 2004 - Deputado BENÍCIO TAVARES - Presidente 


\section{Anexo C: Modelo de Leiper.}

\section{Modelo de LEIPER}

As agências e operadores servem como um elo entre as áreas geradoras e as áreas receptoras do sistema turístico, trabalhando juntamente com os ambientes.

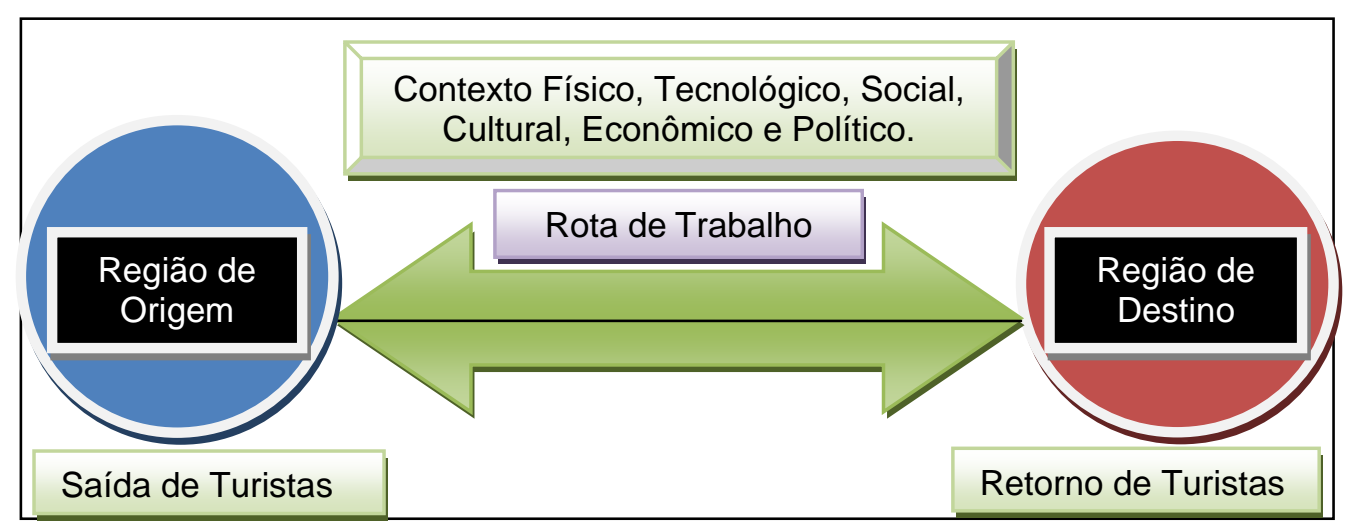

Modelo de LEIPER, Neil. Sistema Turístico Básico.

\section{Anexo D: Cadeias Produtivas Locais}

A Operadora recebe o dinheiro do turista através da Agencia de Viagem que ira distribuir, esse pagamento nos diversos fornecedores locais, quais sejam: city tour, receptivo, hotéis, atrações turísticas, transporte, etc.

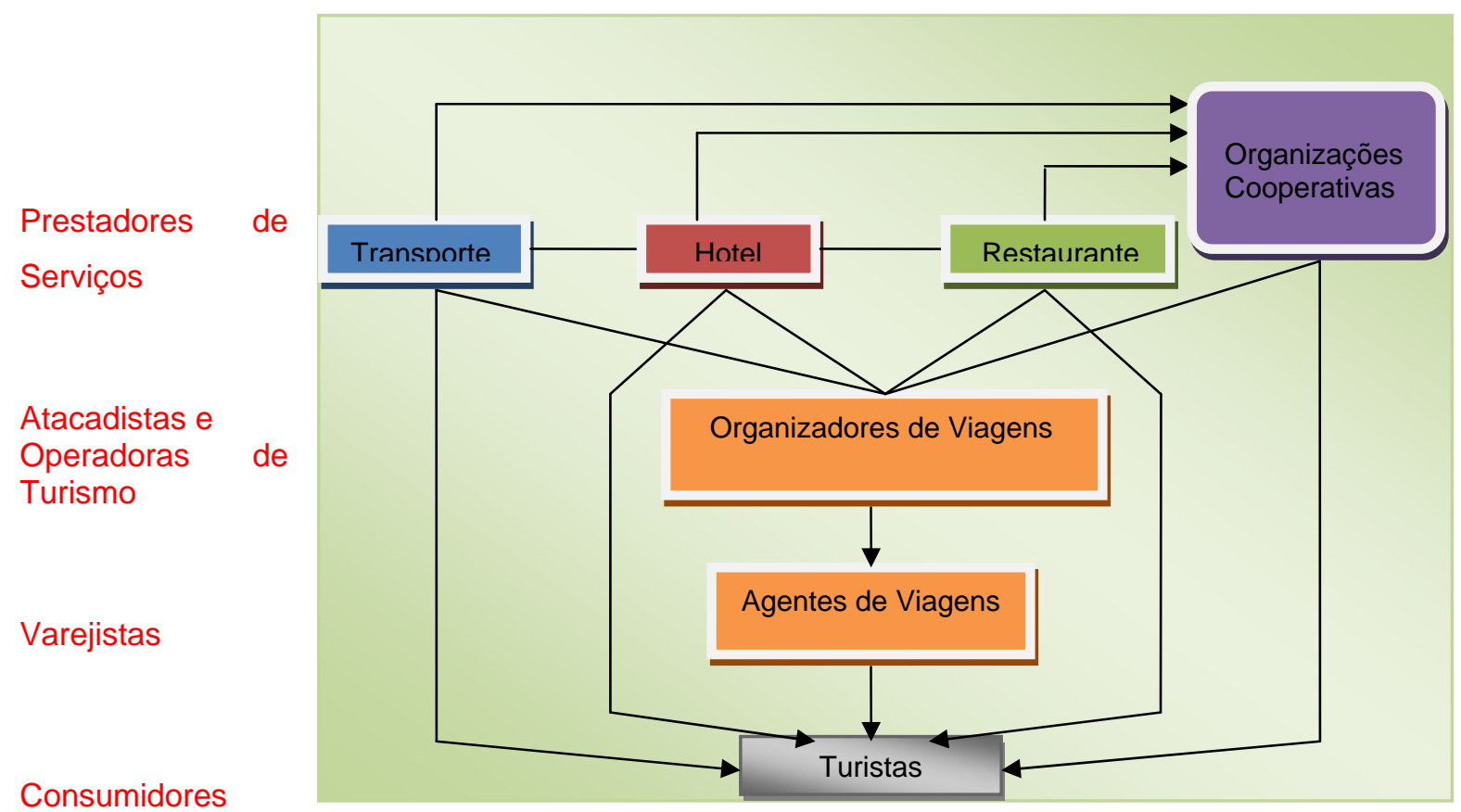

Esquema Básico dos Canais de Comercialização do Turismo 


\section{Anexo E: Decreto 84.934/80 - Atuação das Agências}

Se considerarmos que o agir turístico é próprio, na essência, daquele que se desloca, se aloja e se alimenta etc., vale dizer, daquele que efetua a jornada, fica claro que o plano de atuação dos profissionais do turismo (entre quais os agentes de viagem) é colateral, acessório. O agente turístico, portanto, age para o turismo, empreende atos destinados a viabilizar a concretização, por outra pessoa (seu cliente), da jornada. Uma ação turística profissional e acessória, voltada para uma ação jurídica principal.

Define o Decreto 84.934/80 que a atuação das agências compreende, antes de tudo, serviços que somente poderiam ser por elas praticados, quais sejam:

I - venda comissionada ou intermediação remunerada de passagens individuais ou coletivas, passeios, viagens e excursões;

II - Intermediação remunerada na reserva de acomodações;

III - recepção transferência e assistência especializada ao turista ou viajante;

IV - operação de viagens e excursões, individuais ou coletivas, compreendendo a organização, contratação e execução de programas, roteiros e itinerários;

$V$ - representação de empresas transportadoras, empresas de hospedagem outras prestadoras de serviços turísticos;

VI - divulgação pelos meios adequados, inclusive propaganda e publicidade, dos serviços mencionados nos incisos anteriores.

O próprio Decreto 84.934/80, em seu art. $3^{\circ}$, acrescentou outras que não seriam privativas das agências de turismo. São elas:

I - obtenção e legalização de documentos para viajantes;

II - reserva e venda, mediante comissionamento, de ingressos para espetáculos públicos, artísticos, esportivos, culturais e outros;

III - transporte turístico de superfície;

IV - desembaraço de bagagens nas viagens e excursões de seus clientes;

$V$ - agenciamento de carga; 
VI - prestação de serviços para congressos, convenções, feiras e eventos similares;

VII - operações de cambio manual, observadas as instruções baixadas a esse respeito pelo Banco Central do Brasil;

VIII - outros serviços, que venham a ser especificado pela EMBRATUR.

Para BENI (1998; 145), "os mercados de Turismo inserem-se na categoria 'concorrência imperfeita'. Os produtos não são homogêneos e intercambiáveis, mas diferenciados. Cada empresa vende um produto que de certo modo se traduz como único e diferenciado dos demais e, neste sentido, assemelha-se a uma empresa monopolista. É justamente por essa diferenciação que o mercado de Turismo é quase um monopólio." A afirmação deve ser lida com cautela, como se verifica na seqüência: "Não existem dois hotéis iguais nem instalados no mesmo lugar; o que um oferece, o outro não o fará exatamente da mesma maneira. O roteiro turístico que é produzido e comercializado por uma operadora não é vendido com todos os detalhes por nenhuma outra empresa." 
Anexo F: Capacidade Hoteleira do Distrito Federal

\begin{tabular}{|c|c|}
\hline Hotel & Capacidade Hospedagem \\
\hline Acadêmia de Tênis & 500 \\
\hline Alvimar Hotel & 140 \\
\hline Alvorada & 253 \\
\hline Aracoara & 262 \\
\hline Atlantico Hotel & 184 \\
\hline Arístus Hotel & 115 \\
\hline Bittar Plaza & 184 \\
\hline Blue Tree Park & 598 \\
\hline Blue Tree Towers & 632 \\
\hline Bonaparte & 351 \\
\hline Brasília Imperial & 159 \\
\hline Bristol & 319 \\
\hline Byblos & 98 \\
\hline Carlton & 420 \\
\hline Casablanca & 174 \\
\hline Das Américas & 298 \\
\hline Das Nações & 259 \\
\hline Diplomat & 132 \\
\hline Econotel & 125 \\
\hline El Pilar & 137 \\
\hline Eran Brasília & 371 \\
\hline Grand Bittar & 294 \\
\hline Garvey Park & 159 \\
\hline Hotel Nacional & 794 \\
\hline Hotel Riviera & 100 \\
\hline Kingstown & 280 \\
\hline Kubitschek Plaza & 800 \\
\hline Lake Side & 306 \\
\hline Mercure & 660 \\
\hline Manhattan Plaza & 859 \\
\hline Meliá Confort & 452 \\
\hline Mirage Hotel & 109 \\
\hline Metropollitan & 420 \\
\hline Monumental Plaza & 272 \\
\hline Naoum Plaza & 402 \\
\hline Parthenon Líder & 584 \\
\hline Planalto Bittar & 114 \\
\hline Phenicia Bittar & 310 \\
\hline San Marco & 562 \\
\hline Saint Paul & 573 \\
\hline Saint Peter & 804 \\
\hline Torre Palace & 380 \\
\hline Brasília Park & 184 \\
\hline Pousada Brasília & 120 \\
\hline Mega Apart & 54 \\
\hline Max & 92 \\
\hline Saan Park & 148 \\
\hline Sia Park & 124 \\
\hline 52 & 15.745 \\
\hline
\end{tabular}

